\title{
Ammonia Borane: An Extensively Studied, Though Not Yet Implemented, Hydrogen Carrier
}

\author{
Umit Bilge Demirci
}

Institut Européen des Membranes, IEM-UMR 5635, ENSCM, CNRS, Univ Montpellier, F-34095 Montpellier, France; umit.demirci@umontpellier.fr; Tel.: +33-4-6714-9160

Received: 14 May 2020; Accepted: 11 June 2020; Published: 13 June 2020

check for updates

\begin{abstract}
Ammonia borane $\mathrm{H}_{3} \mathrm{~N}-\mathrm{BH}_{3}(\mathrm{AB})$ was re-discovered, in the 2000s, to play an important role in the developing hydrogen economy, but it has seemingly failed; at best it has lagged behind. The present review aims at analyzing, in the context of more than 300 articles, the reasons why $\mathrm{AB}$ gives a sense that it has failed as an anodic fuel, a liquid-state hydrogen carrier and a solid hydrogen carrier. The key issues $\mathrm{AB}$ faces and the key challenges ahead it has to address (i.e., those hindering its technological deployment) have been identified and itemized. The reality is that preventable errors have been made. First, some critical issues have been underestimated and thereby understudied, whereas others have been disproportionally considered. Second, the potential of $\mathrm{AB}$ has been overestimated, and there has been an undoubted lack of realistic and practical vision of it. Third, the competition in the field is severe, with more promising and cheaper hydrides in front of $\mathrm{AB}$. Fourth, $\mathrm{AB}$ has been confined to lab benches, and consequently its technological readiness level has remained low. This is discussed in detail herein.
\end{abstract}

Keywords: ammonia borane; dehydrocoupling; direct fuel cell; electro-oxidation; energy carrier; hydrogen carrier; hydrogen generation; hydrogen storage; hydrolysis; thermolysis

\section{Introduction}

Recent years have witnessed a renewed interest in hydrogen, which is considered to be a high-potential energy carrier of the near-future energy mix. New momentum has been created at the international level [1] as a result of two decades of intense research and development at both academic and industrial scales. Further efforts are, however, needed to knock down the remaining technological and scientific barriers related to the whole chain of the hydrogen economy, viz. production [2], distribution [3], storage [4,5] and end-use [6,7].

The storage issue is particularly problematic. Also the conventional physical methods (i.e., compression up to $700-900$ bars and liquefaction at $-253^{\circ} \mathrm{C}$ ), new solutions involving materials have been developed $[4,5]$. With porous materials, cryo-adsorption (physisorption) of molecular hydrogen has shown to be effective in allowing high gravimetric hydrogen storage capacities; for instance, higher than $7 \mathrm{wt} \% \mathrm{H}_{2}$ at $-196^{\circ} \mathrm{C}$ [8]. As with all of the other materials, hydrogen storage is chemical and thus involves elemental hydrogen in chemical binding (chemisorption) [9]. There are alkali/alkaline-earth hydrides like magnesium hydride $\mathrm{MgH}_{2}$, intermetallic compounds like lanthanum-nickel alloy $\mathrm{LaNi}_{5}$, complex hydrides like sodium alanate $\mathrm{NaAlH}_{4}$ and chemical hydrides like lithium borohydride $\mathrm{LiBH}_{4}$ [10-14]. There are also BH and BNH materials [15,16], represented by sodium borohydride $\mathrm{NaBH}_{4}$ [17], ammonia borane $\mathrm{H}_{3} \mathrm{~N}-\mathrm{BH}_{3}$ [18] and hydrazine borane $\mathrm{H}_{4} \mathrm{~N}_{2}-\mathrm{BH}_{3}$ [19], for example. Sodium borohydride has been much investigated from the late 1990s, primarily as liquid-state hydrogen carrier, for which the main challenge has been dehydrogenation by catalyzed hydrolysis [20]. After more than 20 years of research, now is the time to scale it up [21]. Ammonia borane emerged in the mid-2000s, firstly as an alternative to sodium borohydride as a liquid-state hydrogen carrier [22], and secondly as 
solid-state hydrogen carrier, where dehydrogenation is driven by thermolytic dehydrocoupling [23]. Ammonia borane is the core subject of the present article, and it will be discussed in length hereafter. With respect to hydrazine borane, it is in some way the latest of the BNH materials [24]. Like ammonia borane, it has been considered to be a liquid-state hydrogen carrier, the challenge also being to dehydrogenate the $\mathrm{N}_{2} \mathrm{H}_{4}$ group of the molecule together with the $\mathrm{BH}_{3}$ group [25]. It has also been seen as solid-state hydrogen carrier, though pristine hydrazine borane has an 'explosive' dehydrogenation behavior under heating [26]. Of course, $\mathrm{BH}$ and $\mathrm{BNH}$ materials are not restricted to the aforementioned three compounds but these three compounds, especially the first two, have been by far the most investigated ones (Figure 1).

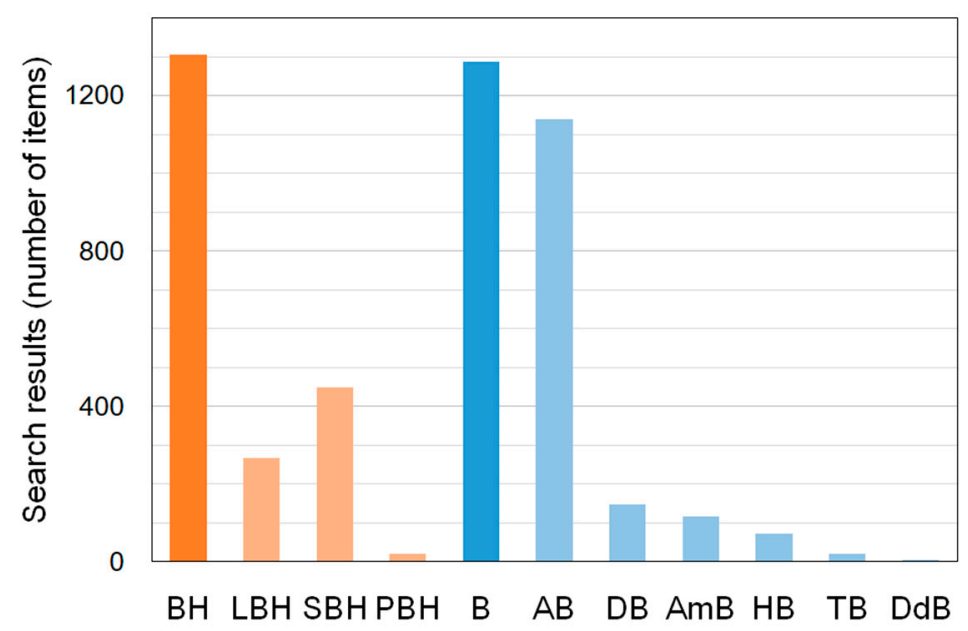

Figure 1. Number of results for a bibliometric resource search made on the Web of Science website the 1st of June 2020. The search was based on the combination: " $X$ " AND "hydrogen storage", where $X$ is borohydride $(\mathrm{BH})$, lithium borohydride $(\mathrm{LBH})$, sodium borohydride $(\mathrm{SBH})$, potassium borohydride $(\mathrm{PBH})$, borane $(\mathrm{B})$, ammonia borane $(\mathrm{AB})$, diborane $(\mathrm{DB})$, amidoboranes $(\mathrm{AmB})$, hydrazine borane $(\mathrm{HB})$, triborane (TB) and dodecaborane (DdB).

Ammonia borane is an old compound. Its history commences before the 2000s, in the first half of the twentieth century [27]; this is addressed in Section 2. Ammonia borane has been the object of a new interest dating back to the mid-2000s. The interest stretched beyond the hydrogen storage application. Ammonia borane has been also considered, though briefly, as a potential liquid fuel for direct liquid-fed fuel cells. This aspect is covered in Section 3. Ammonia borane is a potential liquid-state hydrogen carrier as well as a solid-state hydrogen storage material. Research dedicated to the former use is discussed in Section 4, and that of the latter application is addressed in Section 5. These four sections are put into perspective in Section 6 so as to stress on the main challenges that remain, assess the technological readiness level of the aforementioned applications and give an objective analysis of opportunities for the industrial development of ammonia borane as a hydrogen carrier.

\section{Ammonia Borane, an Old Compound}

Ammonia borane is the result of works carried out by two American research groups between the 1930s and the 1950s. The first research group, led by Schlesinger, long sought to synthesize it [28-32]. All of their attempts were thwarted because of unsuitable experimental conditions in terms of reactants, stoichiometry, temperature and/or solvent [27]. The successful synthesis of ammonia borane, as a crystalline compound, was reported by the second research group, represented by Shore and Parry [33-35]. Ammonia borane was prepared by a metathesis reaction of lithium borohydride with an ammonium salt in diethyl ether, followed by hydrogen evolution by proton-hydride combination, as shown below:

$$
\mathrm{LiBH}_{4}+\mathrm{NH}_{4} \mathrm{Cl} \rightarrow\left[\mathrm{NH}_{4}\right]^{+}\left[\mathrm{BH}_{4}\right]^{-}+\mathrm{LiCl}
$$




$$
\left[\mathrm{NH}_{4}\right]^{+}\left[\mathrm{BH}_{4}\right]^{-} \rightarrow \mathrm{H}_{3} \mathrm{~N}-\mathrm{BH}_{3}+\mathrm{H}_{2}
$$

This is one of the safest paths allowing the synthesis of pure ammonia borane, which is thus being currently used (while consuming different alkali borohydrides like $\mathrm{NaBH}_{4}$ and ammonium salts like $\left.\left(\mathrm{NH}_{4}\right)_{2} \mathrm{SO}_{4}\right)$ [36-42].

As a new compound, ammonia borane was then much studied. For example, the distance of the $\mathrm{N}-\mathrm{B}$ bond of the gas-state molecule was calculated to be $1.66 \AA$ [43]. The formation enthalpy and formation entropy of gas-state ammonia borane were calculated as $-83.3 \mathrm{~kJ} \mathrm{~mol}^{-1}$ and $243.9 \mathrm{~J} \mathrm{~mol}^{-1} \mathrm{~K}^{-1}$, comparing favorably to the values of the isoelectronic ethane $\left(-83.8 \mathrm{~kJ} \mathrm{~mol}^{-1}\right.$ and $\left.229.6 \mathrm{~J} \mathrm{~mol}^{-1} \mathrm{~K}^{-1}\right)$ [44]. The Mulliken charge of $\mathrm{H}^{\delta+}$ and that of $\mathrm{H}^{\delta-}$ of ammonia borane were calculated as +0.21 and -0.195 , respectively [45]. An electron transfer from the $\mathrm{H}_{3} \mathrm{~N}$ group to the $\mathrm{BH}_{3}$ one was evidenced [46], in good agreement with the formation of a dative bond between the two groups. The ammonia borane molecule is polarized, and a dipole moment of about 5.6 $\mathrm{D}$ was calculated, for instance [47]. As discussed at length in references $[18,48,49]$, ammonia borane as a molecule was studied extensively between the 1960s and the 1980s, and ammonia borane as a material has been well studied within the past there decades. For example, the crystal structure of the material, though first determined in the 1950s [33,50,51], was scrutinized more in detail (at different temperatures and under pressure) in recent years [52-54]. It is now known that, at atmospheric pressure, ammonia borane has a low-temperature phase (orthorhombic, space group $P m n 2_{1}$ ) and a high-temperature phase (tetragonal $14 \mathrm{~mm}$ ), the transition taking place at $-48^{\circ} \mathrm{C}$. The recent interest on ammonia borane as a material has been explained by its promises as a solid-state hydrogen carrier [55]. This is discussed in the next sections.

However, the capacity of ammonia borane to generate hydrogen (i.e., its role as a hydrogen carrier) has long been recognized. Between the 1960s and the early 1980s, it was patented as a solid propellant hydrogen generator [56-59]. Recent works confirmed the properties of ammonia borane as a propellant and an energetic material [60-65], but efforts in this direction have been limited. Today, ammonia borane is first and foremost considered to be a hydrogen carrier, with the released hydrogen being used for electricity generation by conversion in a fuel cell.

\section{Aqueous Ammonia Borane as Anodic Fuel}

Ammonia borane is a water-soluble reductant that can be electro-oxidized in alkaline conditions at metal (e.g., gold) electrodes [66], the reaction being often reported as

$$
\mathrm{H}_{3} \mathrm{~N}-\mathrm{BH}_{3}+6 \mathrm{OH}^{-} \rightarrow \mathrm{BO}_{2}^{-}+\mathrm{NH}_{4}^{+}+4 \mathrm{H}_{2} \mathrm{O}+6 \mathrm{e}^{-}
$$

However, in the electro-oxidation conditions $\left(<30^{\circ} \mathrm{C}\right.$ and $\left.<1 \mathrm{~mol} \mathrm{~L}^{-1}\right)$, the anhydrous borate anion $\mathrm{BO}_{2}{ }^{-}$cannot form, since the thermodynamically stable form is the dihydrated one, namely the tetrahydroxyborate anion $\mathrm{B}(\mathrm{OH})_{4}{ }^{-}$[67]. The following reaction is thus more accurate:

$$
\mathrm{H}_{3} \mathrm{~N}-\mathrm{BH}_{3}+6 \mathrm{OH}^{-} \rightarrow \mathrm{B}(\mathrm{OH})_{4}^{-}+\mathrm{NH}_{4}^{+}+2 \mathrm{H}_{2} \mathrm{O}+6 \mathrm{e}^{-}
$$

Each of the hydridic hydrogens $\mathrm{H}^{\delta-}$ of the $\mathrm{BH}_{3}$ group of ammonia borane are electro-oxidized into a proton while two electrons per hydrogen are released. These electrons can then be involved in an electro-reduction reaction; that of oxygen $\mathrm{O}_{2}$, for example:

$$
3 / 2 \mathrm{O}_{2}+3 \mathrm{H}_{2} \mathrm{O}+6 \mathrm{e}^{-} \rightarrow 6 \mathrm{OH}^{-}
$$

These reactions form the basis of the direct ammonia borane fuel cell (DABFC; Figure 2), for which the overall reaction is:

$$
\mathrm{H}_{3} \mathrm{~N}-\mathrm{BH}_{3}+3 / 2 \mathrm{O}_{2}+\mathrm{H}_{2} \mathrm{O} \rightarrow \mathrm{B}(\mathrm{OH})_{4}{ }^{-}+\mathrm{NH}_{4}{ }^{+}
$$



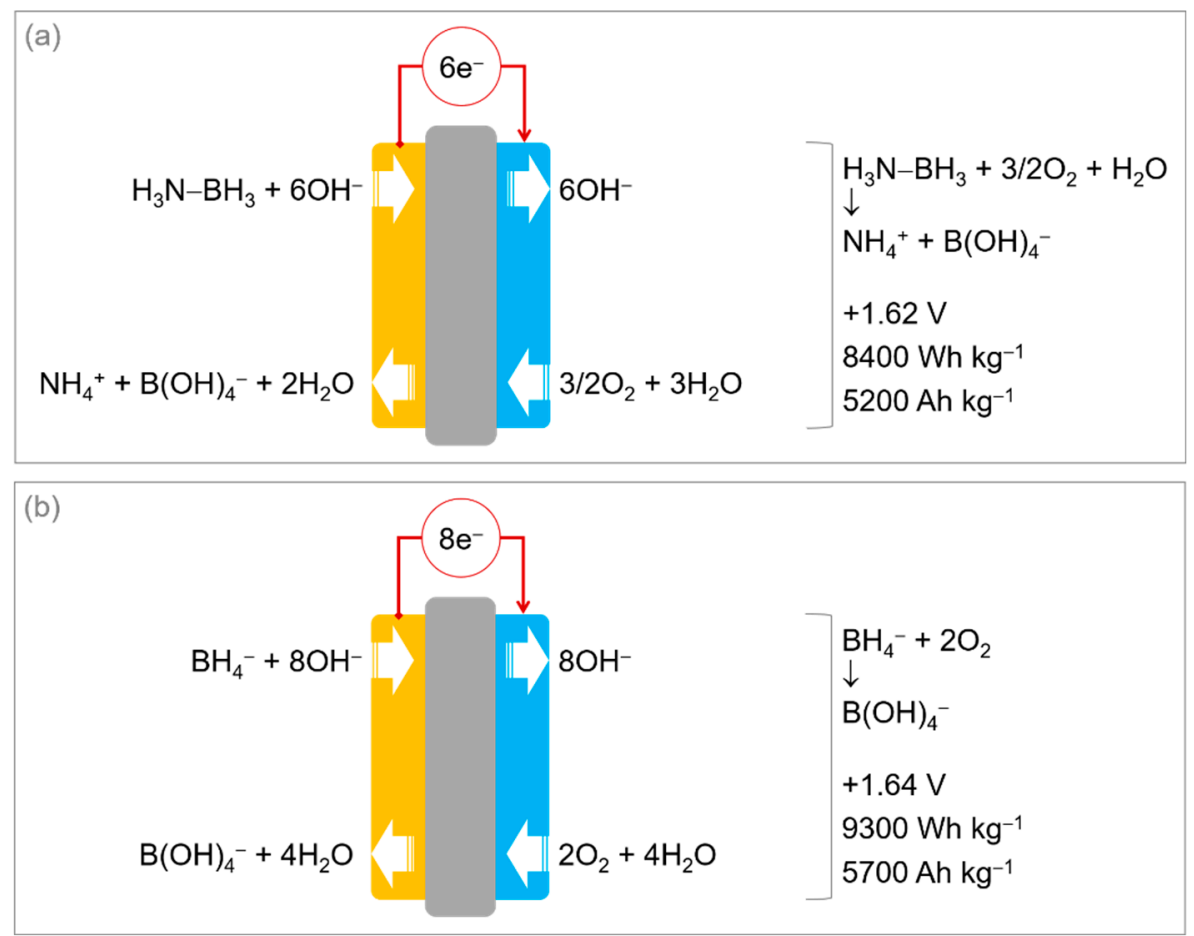

Figure 2. Schematic representation of (a) the direct ammonia borane fuel cell and (b) the direct borohydride fuel. At the right is given the standard potential versus the standard hydrogen electrode, the specific energy and the pure compound capacity. The anode (in yellow) and the cathode (in blue) are separated by a mmebrane (in grey).

Theoretically, the fuel cell features a standard potential of $+1.62 \mathrm{~V}$ versus the standard hydrogen electrode, a specific energy of $8400 \mathrm{Wh} \mathrm{kg}^{-1}$ and a pure compound capacity of $5200 \mathrm{Ah} \mathrm{kg}^{-1}$ [68,69]. For comparison, the direct borohydride fuel cell (Figure 2) has the following properties: theoretically, eight electrons released per borohydride anion $\mathrm{BH}_{4}{ }^{-}$, a standard potential of $+1.64 \mathrm{~V}$ versus the standard hydrogen electrode, specific energy of $9300 \mathrm{Wh} \mathrm{kg}^{-1}$ and pure compound capacity of $5700 \mathrm{Ah} \mathrm{kg}^{-1}$ [70]. In operation, the borohydride cell should be slightly better performing.

The first DABFC was reported by Yao et al. [71]. They isolated an efficient silver anode electrocatalyst (among other metals like platinum and gold), and manganese oxide $\mathrm{MnO}_{2}$ as a cathode electrocatalyst showing tolerance to ammonia borane. The fuel cell showed, at ambient temperature, an energy density of about $2000 \mathrm{mAh} \mathrm{g}^{-1}$ at $1 \mathrm{~mA} \mathrm{~cm}^{-2}$ and $0.9 \mathrm{~V}$. Shortly afterward, Zhang et al. [68,69] reported their DABFC made of a carbon-supported platinum (30-46.6 $\mathrm{wt} \%$ ) electrodes, showing a power density of $110 \mathrm{~mW} \mathrm{~cm}{ }^{-2}$ at $185 \mathrm{~mA} \mathrm{~cm}^{-2}, 0.6 \mathrm{~V}$ and $45^{\circ} \mathrm{C}$. These studies opened the way for developing efficient anode electrocatalysts, which were especially inactive towards the unwanted heterogeneous hydrolysis of ammonia borane:

$$
\begin{gathered}
\mathrm{H}_{3} \mathrm{~N}-\mathrm{BH}_{3}+3 \mathrm{H}_{2} \mathrm{O} \rightarrow \mathrm{NH}_{3}+\mathrm{B}(\mathrm{OH})_{3}+3 \mathrm{H}_{2} \\
\mathrm{H}_{3} \mathrm{~N}-\mathrm{BH}_{3}+4 \mathrm{H}_{2} \mathrm{O} \rightarrow \mathrm{NH}_{4}^{+}+\mathrm{B}(\mathrm{OH})_{4}{ }^{-}+3 \mathrm{H}_{2}
\end{gathered}
$$

Zhang et al. [72] worked on electro-oxidation on a gold electrode in the presence of thiourea. Direct electro-oxidation was found to occur, but the number of electrons exchanged was determined as being two, out of the theoretical maximum of six, because of the occurrence of hydrolysis. Belén Molina Concha et al. [73] confirmed, by on-line differential electrochemical mass spectrometry and in situ Fourier transform infrared spectroscopy, the occurrence of heterogeneous hydrolysis, especially at low potential. Hydrogen was detected, and the number of electrons exchanged was found 
to be about three. At higher potential, above $0.6 \mathrm{~V}$, the number of electrons was about six because of preponderant electro-oxidation. The authors stressed the key role of the intermediate species $\mathrm{BH}_{3} \mathrm{OH}^{-}$:

$$
\begin{gathered}
\mathrm{H}_{3} \mathrm{~N}-\mathrm{BH}_{3}+\mathrm{OH}^{-} \rightarrow \mathrm{NH}_{3}+\mathrm{BH}_{3} \mathrm{OH}^{-} \\
\mathrm{BH}_{3} \mathrm{OH}^{-}+\mathrm{NH}_{3}+5 \mathrm{OH}^{-} \rightarrow \mathrm{B}(\mathrm{OH})_{4}^{-}+\mathrm{NH}_{4}^{+}+2 \mathrm{H}_{2} \mathrm{O}+6 \mathrm{e}^{-}
\end{gathered}
$$

Nagle et al. [74,75] focused on gold in nanoporous morphology. The electrode was more active than bulk gold, with an oxidation current of $13.1 \mathrm{~mA} \mathrm{~cm}^{-2}$ versus $2.65 \mathrm{~mA} \mathrm{~cm}{ }^{-2}$. Barsuk et al. [76] also showed the beneficial effect of the nanoporous morphology, in their case for a silver anode electrocatalyst. To further enhance the electrocatalytic activity of gold, Karabiberoğlu et al. [77] alloyed it with silver. Zhang et al. [78] focused on core-shell nanoparticles with an amorphous core of iron and a shell of platinum. They were much more active than commercial platinum (with about 2.5 and $0.75 \mathrm{~mA}$ $\mu \mathrm{g}^{-1}$ respectively at $-0.7 \mathrm{~V}$ ). Kiran et al. [79] developed a titanium carbide anode electrocatalyst. A fuel cell made of it, and of carbon-supported platinum as the cathode, generated a maximum power density of $85 \mathrm{~mW} \mathrm{~cm}^{-2}$ at $105 \mathrm{~mA} \mathrm{~cm}{ }^{-2}$ and $80^{\circ} \mathrm{C}$. Olu et al. [80] explored the potential of a carbon-supported palladium anode electro-catalyst. A peak power density of $181 \mathrm{~mW} \mathrm{~cm}{ }^{-2}$ was measured at $25^{\circ} \mathrm{C}$, with a similar performance being found for a comparable platinum electro-catalyst. Above all, this work showed that the performance depends on the anode's texture. Zadick et al. [81] alloyed palladium with nickel, such as $\mathrm{Ni}_{3} \mathrm{Pd}$ nanoparticles, supported onto a carbon support. Alternatively, silver and cobalt were used instead of palladium. The noble-free nickel-cobalt nanoparticles exhibited the best results, being both active and durable in the ammonia borane electro-oxidation conditions. Wang et al. [82] confirmed the potential of noble metal-free nickel-based electro-catalysts, especially that of carbon fiber-supported nanowires of nickel-copper selenide (better performing than the iron and cobalt counterparts). Similar conclusions were obtained by $\mathrm{Wu}$ et al. [83]. They successfully developed carbon fiber supported porous nickel-copper oxide nanowire arrays that showed a low onset potential with $-0.316 \mathrm{~V}$ and high faradic efficiency $(>98 \%)$, for example.

The electro-oxidation of ammonia borane has been little studied in comparison with the electro-oxidation of the borohydride anion of sodium borohydride. The fuel cells based on these two reactions are, however, comparable, in particular as regards the issues they both suffer from. The first main issue is, as briefly reported above, the occurrence of metal electrode-catalyzed heterogeneous hydrolysis that competes with the electro-oxidation reaction and lowers the number of electrons exchanged, and thus the faradic capacity of ammonia borane. The second main issue is about crossover of ammonia borane or other intermediate species through the ion exchange membrane of the fuel cell [72]: the ammonium ion $\mathrm{NH}_{4}{ }^{+}$(Equation (5)) is likely to crossover a cation exchange membrane, and the key intermediate species $\mathrm{BH}_{3} \mathrm{OH}^{-}$is prone to crossover an anion exchange membrane. Crossover is harmful for the performance of the cathode electro-catalyst. As far as is known, there is no study reporting a membrane specifically developed for a direct ammonia borane fuel cell. On a final matter, ammonia borane necessarily costs more than sodium borohydride, as the former is synthesized from the latter [18]. The electro-oxidation of ammonia borane is very likely facing another issue, which has been neglected so far. In aqueous solution, ammonia borane generates ammonium ions in equilibrium with ammonia, and these species (a weak Brønsted acid and a Lewis base, respectively) may have a negative effect on the fuel cell by deteriorating the electrode, the electro-catalyst and/or the membrane.

The features of ammonia borane as an anodic fuel are less attractive than those of sodium borohydride. This can explain why, in comparison, the electro-oxidation of ammonia borane has been little studied. Few fuel cells were constructed and tested, but these efforts remained at the lab scale and, in any case, the technology appears to have been abandoned now.

The electro-oxidation of ammonia borane remains of scientific interest. There is much to be learned from it, with regard to the intermediate species $\mathrm{BH}_{3} \mathrm{OH}^{-}$(Equation (8)), for example. This species is believed to play an important role in the electro-oxidation of the borohydride anion as well [84], 
and the electro-oxidation of ammonia borane might allow better understanding of the electro-oxidation of the borohydride anion.

\section{Ammonia Borane in Solution as a Liquid-State Hydrogen Carrier}

\subsection{In Water}

From a technological point of view, the hydrolysis of ammonia borane (Equations (6) and (7)) does not present any advantage over the hydrolysis of sodium borohydride. This is discussed hereafter. In all aspects, the latter reaction is superior (Figure 3). Evidence of this comes from the fact that the hydrolysis of ammonia borane has not been scaled up yet: no demonstrator, nor prototype and device, has been reported, and the effective gravimetric hydrogen storage capacity of the couple ammonia borane-water under operation is unknown [21].

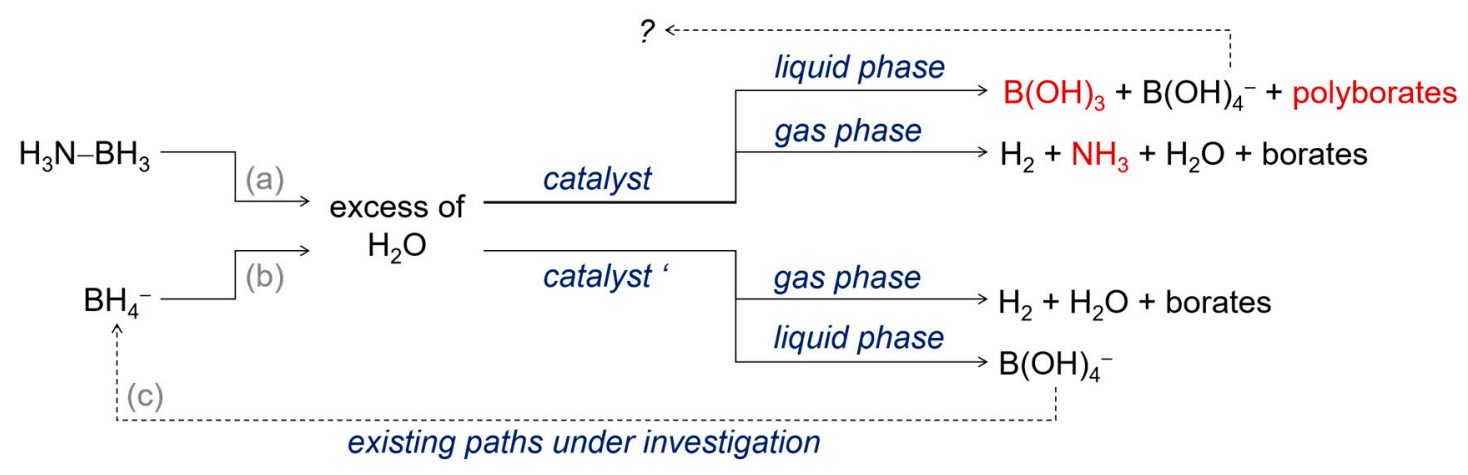

Figure 3. (a) Hydrolysis of ammonia borane. (b) Hydrolysis of sodium borohydride. (c) Recycling of the sodium borohydride hydrolysis product. In red are shown the main differences between path (a) and path $(\mathbf{b})$, thereby making the latter superior.

The hydrolysis of ammonia borane has been studied extensively. However, the vast majority of the published articles deal with catalysts and how fast the catalysts allow the completion of the release of hydrogen. Listing the catalysts reported since 2006 [22] goes beyond the scope of the present article. The reader is warmly referred to the almost-yearly published reviews authored by active researchers in this field, like $\mathrm{Xu}$ and co-workers [85-89], Özkar and co-workers [90,91] and other groups [92-96]. Catalysts in various forms have been investigated. Metal organic framework-supported metal nanoparticles [97-99], silica-supported bi-/ter-nary composites [100-103], graphene-containing catalytic materials [104-107], nitride as active phase supports [108-110], cobalt-based alloys and catalysts [111-115], nickel-based systems [116-118], supported ruthenium nanostructures [119-122] and palladium-based materials [123-126] are examples among the catalysts reported within the last three years. Such efforts have allowed the development of many active heterogeneous catalysts like the rhodium nanoparticles supported over cobalt (II, III) oxide, which attained a turnover frequency of $1800 \mathrm{~min}^{-1}$ and a total of $1.02 \times 10^{6}$ turnovers for hydrogen release at $25^{\circ} \mathrm{C}$ [127].

Improved catalytic performance will take place certainly and soon, achieved by means of further changes and developments. The number of potential heterogenous catalysts is illimited. This may be illustrated as follows. Starting with twelve transition metals (i.e., $\mathrm{Fe}, \mathrm{Co}, \mathrm{Ni}, \mathrm{Cu}, \mathrm{Zn}, \mathrm{Ag}, \mathrm{Pd}$, $\mathrm{Rh}, \mathrm{Ru}, \mathrm{Ir}, \mathrm{Pt}, \mathrm{Au}$ ) and considering bi- and tri-atomic systems with these metals, as well as other elements like B and P, there would be more than 2900 combinations (Figure 4). Then, supporting these combinations onto various supports (e.g., silica or carbon in various forms, nitrides, graphene and modified graphene, metal organic frameworks which exceed 10,000 candidates and so forth), for example onto ten supports for example, there would be more than 40,000 potential catalysts. The possibilities seem to be almost limitless. 


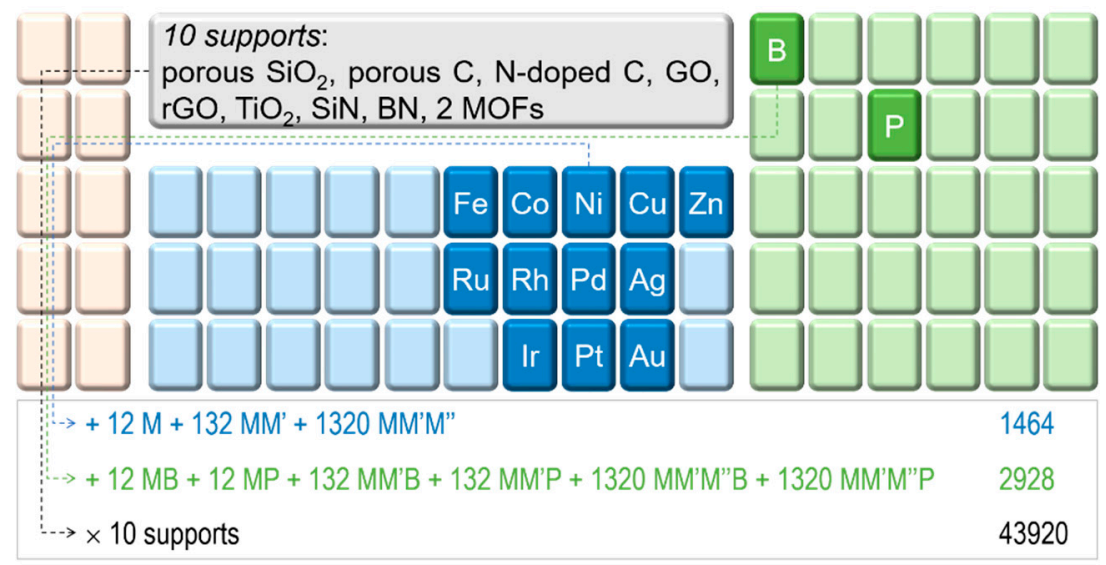

Figure 4. More than 40,000 potential heterogeneous metal-based catalysts, based on the combinations of 10 metals (mono-, bi- and tri-metallic systems, represented by $\mathrm{M}, \mathrm{MM}^{\prime}$ and $\mathrm{MM}^{\prime} \mathrm{M}^{\prime \prime}$ respectively), the addition of an element like boron (B) or phosphorus (P) and supporting onto ten different supports.

However, the hydrolysis reaction goes beyond the catalytic accelerator. According to Equation (6), water as a reactant, and ammonia and boric acid as by-products have to be taken into account. According to Equation (7), where there is a slight excess of water in comparison to the reaction shown by Equation (6), the by-product is ammonium tetrahydroxyborate. Each of these reactant and by-products are important, at least as important as the catalyst, but little attention has been paid to them.

Water is, first and foremost, a reactant. Half of the released $\mathrm{H}_{2}$ is due to it, as one hydridic hydrogen $\mathrm{H}^{\delta-}$ of the $\mathrm{BH}_{3}$ group of ammonia borane reacts with one protic hydrogen $\mathrm{H}^{\delta+}$ of water:

$$
\begin{gathered}
\mathrm{H}_{3} \mathrm{~N}-\mathrm{B}\left(\mathrm{H}_{2}\right)-\mathrm{H}^{\delta-}+\mathrm{H}^{\delta+}-\mathrm{OH} \rightarrow \mathrm{H}_{3} \mathrm{~N}-\mathrm{B}\left(\mathrm{H}_{2}\right) \cdots \mathrm{H}^{\delta-} \ldots \mathrm{H}^{\delta+} \ldots \mathrm{OH} \\
\mathrm{H}_{3} \mathrm{~N}-\mathrm{B}\left(\mathrm{H}_{2}\right) \cdots \mathrm{H}^{\delta-} \cdots \mathrm{H}^{\delta+} \ldots \mathrm{OH} \rightarrow \mathrm{H}_{3} \mathrm{~N}-\mathrm{B}\left(\mathrm{H}_{2}\right)-\mathrm{OH}+\mathrm{H}_{2}
\end{gathered}
$$

No side-reaction exists, which makes the hydrogen generation so simple. Water is almost always used in excess. This makes sense when a catalyst is under development. Accordingly, water is also a solvent. However, this makes no sense when the application is foreseen because of a negative impact on the storage capacities (Figure 5). When water is used in stoichiometric conditions (Equations (6) and (7)), the theoretical gravimetric hydrogen storage capacities of the couple ammonia borane-water is 7.1 and $5.8 \mathrm{wt} \% \mathrm{H}_{2}$, respectively. The solubility limit of ammonia borane in water is $11.4 \mathrm{~mol} \mathrm{~L}^{-1}$ [128], which is similar to a molar ratio $\mathrm{H}_{2} \mathrm{O} / \mathrm{H}_{3} \mathrm{~N}-\mathrm{BH}_{3}$ of 4.9 and a theoretical gravimetric hydrogen storage capacity of about $5 \mathrm{wt} \% \mathrm{H}_{2}$. At lower concentrations of ammonia borane, e.g., $1 \mathrm{~mol} \mathrm{~L}^{-1}$ (and even lower), as in those applied for investigating a wide variety of heterogeneous catalysts, the theoretical gravimetric hydrogen storage capacity is lower than $0.6 \mathrm{wt} \% \mathrm{H}_{2}$, thus precluding any technological perspective. A very limited number of studies have explored the use of ammonia borane in a solid state (as powder [129] or in the form of pellets [130]) combined with the addition of water in near-stoichiometric conditions. In a recent work, an all-in-one formulation consisting of nickel nanoparticles intimately combined to $A B$ nanoparticles was reacted with a limited amount of water [129]. An effective gravimetric hydrogen storage capacity of $4.8 \mathrm{wt} \% \mathrm{H}_{2}$ was determined at $43.3^{\circ} \mathrm{C}$, whereas the conversion was lower than $100 \%$ (i.e., $78.3 \%$ ). Further improvements in the composite formulation should allow the achievement of higher capacities, the target being $6.8 \mathrm{wt} \% \mathrm{H}_{2}$. 


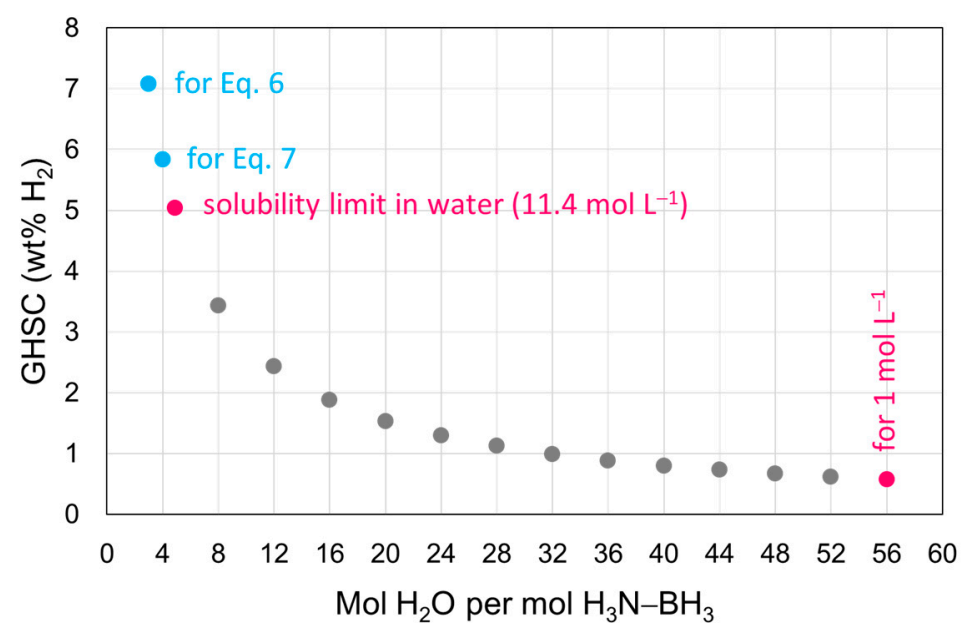

Figure 5. Evolution of the gravimetric hydrogen storage capacity (GHSC) of the couple ammonia borane-water as a function of the mole number of water per mole of ammonia borane. The capacities (7.1 and $5.8 \mathrm{wt}_{\mathrm{t}} \mathrm{H}_{2}$ ) in stoichiometric conditions (Equations (6) and (7)) are shown. The capacities calculated for an ammonia borane concentration of $11.4 \mathrm{~mol} \mathrm{~L}^{-1}$ (solubility limit of ammonia borane in water) and a concentration of $1 \mathrm{~mol} \mathrm{~L}^{-1}$ are also shown (5 and $0.6 \mathrm{wt} \% \mathrm{H}_{2}$ respectively).

The hydrolysis of ammonia borane is often compared to that of sodium borohydride to underline the similarities between these two reactions. There is, however, a substantial difference. Ammonia is generated when ammonia borane is used. Ammonia is highly soluble in water and reacts to form its acidic form $\left(\mathrm{pK}_{\mathrm{a}}=9.25\right)$ :

$$
\mathrm{NH}_{3}+\mathrm{H}_{2} \mathrm{O} \leftrightarrow \mathrm{NH}_{4}^{+}+\mathrm{OH}^{-}
$$

This does not hinder the loss of some ammonia in the gas phase, which is also exacerbated by the exothermic nature $\left(-156 \mathrm{~kJ} \mathrm{~mol}^{-1}\right)$ of the hydrolysis reaction [131]. This is well known, especially since the work published by Ramachandran and Gagare in 2007 [37]. The point is that ammonia is thermodynamically stable in hydrolytic conditions (enthalpy of dehydrogenation of $92.4 \mathrm{~kJ} \mathrm{~mol}^{-1}$ ); in other words, it cannot be dehydrogenated at a temperature below $600{ }^{\circ} \mathrm{C}$ [132]. Hence, the release of some ammonia together with hydrogen is unavoidable. The issue can be addressed by using a trap consisting of an aqueous solution of sulfuric acid [133] or of copper sulfate [128]. This is an efficient approach for a laboratory set-up. It is, however, questionable whether such a trap is implementable for a scaled-up device. The fact is that the ammonia problem is being grossly underrated whilst ammonia is detrimental to low-temperature polymer electrolyte membrane fuel cells (because of the poisoning of platinum anode and reaction with acidic membrane) [134].

As mentioned above, the hydrolysis reaction is spontaneous, and thus exothermic. This has negative consequences. The exothermicity of the reaction means that some water is vaporized and expelled out together with the generated hydrogen. Borates are very likely to be carried out by the steam. No report has been found on this, but such an issue was reported for the exothermic hydrolysis of sodium borohydride [135]. In such conditions, hydrogen is not pure, water condensates on any cold surface and the carried borates precipitate in the piping, resulting in accumulation and the clogging of the system. Such problems were encountered in operation conditions for a commercial device based on the hydrolysis of sodium borohydride [136].

The exothermicity of the hydrolysis reaction also means that there is a transition from a reactive $\mathrm{B}-\mathrm{H}$ bond in $\mathrm{H}_{3} \mathrm{~N}-\mathrm{BH}_{3}$ to a stable $\mathrm{B}-\mathrm{O}$ bond, e.g., in $\mathrm{B}(\mathrm{OH})_{3}$ (Equation (6)). Borates are indeed a stable species, the $\mathrm{B}-\mathrm{O}$ bond being relevantly compared to the $\mathrm{C}-\mathrm{O}$ bond of carbon dioxide [137]. They are hardly transformed, that is, reduced, back into the starting hydride, whether it be sodium borohydride [138] or ammonia borane, but it should be noted that the direct or indirect regeneration of 
ammonia borane from the borates forming upon hydrolysis has not been investigated yet. This might be explained by the fact that more than one borate forms upon the hydrolysis of ammonia borane.

As shown by Equations (6) and (7), two borates are likely to form, i.e., boric acid $\mathrm{B}(\mathrm{OH})_{3}$ and the tetrahydroxyborate anion $\mathrm{B}(\mathrm{OH})_{4}{ }^{-}$, especially for diluted aqueous solutions $[133,139]$. In addition to these species, other unidentified borates have been suggested [22,131]. The reaction of $\mathrm{B}(\mathrm{OH})_{3}$ and $\mathrm{B}(\mathrm{OH})_{4}{ }^{-}$to form equilibria towards borates is in fact well documented [140-142]. Rachiero et al. [143] suggested the formation of polyborates:

$$
2 \mathrm{~B}(\mathrm{OH})_{3}+\mathrm{B}(\mathrm{OH})_{4}{ }^{-} \leftrightarrow \mathrm{B}_{3} \mathrm{O}_{3}(\mathrm{OH})_{4}{ }^{-}+3 \mathrm{H}_{2} \mathrm{O}
$$

For concentrated aqueous solutions $\left(10.8 \mathrm{~mol} \mathrm{~L}^{-1}\right)$, a tetraborate like $\left(\mathrm{NH}_{4}\right)_{2} \mathrm{~B}_{4} \mathrm{O}_{5}(\mathrm{OH})_{4} \cdot 1.4 \mathrm{H}_{2} \mathrm{O}$ was reported by Ramachandran and Gagare [37]. Recently, for a comparable concentrated solution $(10 \mathrm{~mol} \mathrm{~L}-1)$, Valero-Pedraza et al. [144] observed the precipitation of $\left(\mathrm{NH}_{4}\right)_{2} \mathrm{~B}_{4} \mathrm{O}_{5}(\mathrm{OH})_{4} \cdot 2 \mathrm{H}_{2} \mathrm{O}$. The formation of this species was supposed to be as follows:

$$
4 \mathrm{H}_{3} \mathrm{~N}-\mathrm{BH}_{3}+11 \mathrm{H}_{2} \mathrm{O} \rightarrow\left(\mathrm{NH}_{4}\right)_{2} \mathrm{~B}_{4} \mathrm{O}_{5}(\mathrm{OH})_{4} \cdot 2 \mathrm{H}_{2} \mathrm{O}+2 \mathrm{NH}_{3}+12 \mathrm{H}_{2}
$$

According to this path, there are two free ammonia molecules. If lost, they could not be integrated into the recycling cycle of the borates, which would run counter to a few green chemistry principles [145]. The tetraborate $\left(\mathrm{NH}_{4}\right)_{2} \mathrm{~B}_{4} \mathrm{O}_{5}(\mathrm{OH})_{4} \cdot 2 \mathrm{H}_{2} \mathrm{O}$ is an analog of borax $\mathrm{Na}_{2} \mathrm{~B}_{4} \mathrm{O}_{5}(\mathrm{OH})_{4} \cdot 2 \mathrm{H}_{2} \mathrm{O}$, and borax is one of the reactants used for the industrial production of sodium borohydride via the so-called Brown-Schlesinger process. These findings suggest that, with sustained efforts, one may gain a better understanding of these borate species while working on their imperative recyclability. In any case, the recyclability requires a large amount of energy, and the cost of the process will be dependent on the energy cost [146], suggesting the crucial role of green electricity for efficient cost reduction [147].

\subsection{In Methanol}

Methanol can be used instead of water as a source of protic hydrogens $\mathrm{H}^{\delta+}$ that can react with the hydridic hydrogens $\mathrm{H}^{\delta-}$ of ammonia borane. The first report about the methanolysis of ammonia borane dates back to 2007, and it is insightful on several levels. Ramachandran and Gagare [37], after comparing a series of aliphatic alcohols, found that methanol provided the best results. The couple ammonia borane-methanol, in the presence of $1 \mathrm{~mol} \%$ ruthenium chloride, was able to generate 3 equivalents of hydrogen in less than $1 \mathrm{~min}$ at ambient conditions. However, a $15 \%$ excess of methanol was found to be necessary to obtain the three equivalents of hydrogen (Equation (15)). A precipitating "crude borate" was isolated and identified as being an ammonium tetramethoxyborate salt such as $\left[\mathrm{NH}_{4} \mathrm{~B}\left(\mathrm{OCH}_{3}\right)_{4}\right]_{5} \cdot 2 \mathrm{CH}_{3} \mathrm{OH}$ :

$$
5 \mathrm{H}_{3} \mathrm{~N}-\mathrm{BH}_{3}+22 \mathrm{CH}_{3} \mathrm{OH} \rightarrow\left[\mathrm{NH}_{4} \mathrm{~B}\left(\mathrm{OCH}_{3}\right)_{4}\right]_{5} \cdot 2 \mathrm{CH}_{3} \mathrm{OH}+15 \mathrm{H}_{2}
$$

It is not clearly specified whether the methanolic solution, in addition to the precipitating "crude borate", was analyzed or not. It is also not clearly specified whether the purity of the released hydrogen was analyzed or not. Interestingly, the recyclability of the ammonium tetramethoxyborate salt was investigated. It was transformed back into ammonia borane (yield $81 \%$ and purity $>98 \%$ ), by using lithium alanate $\mathrm{LiAlH}_{4}$ as a reducing agent and ammonium chloride $\mathrm{NH}_{4} \mathrm{Cl}$ as a source of ammonia:

$$
\begin{gathered}
{\left[\mathrm{NH}_{4} \mathrm{~B}\left(\mathrm{OCH}_{3}\right)_{4}\right]_{5} \cdot 2 \mathrm{CH}_{3} \mathrm{OH}+5 \mathrm{NH}_{4} \mathrm{Cl}+5 \mathrm{LiAlH}_{4}} \\
\rightarrow 5 \mathrm{H}_{3} \mathrm{~N}-\mathrm{BH}_{3}+5 \mathrm{Al}\left(\mathrm{OCH}_{3}\right)_{3}+7 \mathrm{CH}_{3} \mathrm{OH}+\mathrm{H}_{2}+5 \mathrm{LiCl}+5 \mathrm{NH}_{3}
\end{gathered}
$$

The reaction was performed in a sealed reactor, with tetrahydrofuran as a solvent, for $8 \mathrm{~h}$ at ambient conditions. Hence, the cycle was closed. From this work, four interesting aspects stand out: an excess of methanol is required to obtain a conversion of $100 \%$, one of the by-products is a polyborate 
salt, the release (or not) of ammonia is unclear, and the polyborate salt can be effectively recycled back into ammonia borane.

While the aforementioned report has the advantage of putting several aspects of the methanolysis reaction forward, none of these aspects has been the subject of a systematic and deep investigation. As for the hydrolysis reaction, efforts have been focused on heterogeneous catalysts. Listing the catalysts reported since 2007 goes beyond the scope of the present article. The reader may refer to a recent review article [148]. A variety of nanostructured transition metal catalysts (also called nanocatalysts) have been developed, with a special focus on copper [149-152], cobalt [153] and cobalt-palladium combinations [154,155], nickel [153,156,157], palladium [158-160], rhodium [161-164] and ruthenium [165-167].

The reaction shown by Equation (16) was proposed to explain the formation of the ammonium tetramethoxyborate salt $\left[\mathrm{NH}_{4} \mathrm{~B}\left(\mathrm{OCH}_{3}\right)_{4}\right]_{5} \cdot 2 \mathrm{CH}_{3} \mathrm{OH}$, forming from an aqueous solution of ammonia borane at $2 \mathrm{~mol} \mathrm{~L}^{-1}$ [37]. For more diluted solutions, the following equation is generally reported:

$$
\mathrm{H}_{3} \mathrm{~N}-\mathrm{BH}_{3}+4 \mathrm{CH}_{3} \mathrm{OH} \rightarrow \mathrm{NH}_{4}{ }^{+}+\mathrm{B}\left(\mathrm{OCH}_{3}\right)_{4}{ }^{-}+3 \mathrm{H}_{2}
$$

When the literature is reviewed, it stands out that this reaction is rather unknown. The amount of methanol has not been optimized in order to optimize the effective gravimetric hydrogen storage capacity of the couple ammonia borane-methanol (versus the theoretical value of $3.8 \mathrm{wt} \% \mathrm{H}_{2}$ for the stoichiometry in Equation (17) (Figure 6). The release of some ammonia, together with hydrogen, has not been checked and measured. The nature of the borate by-products, depending on the amount of methanol used and/or the drying process, has not been determined yet, except for the aforementioned tetramethoxyborate salt. The knowledge generated by the hydrolysis reaction suggests that the effective capacities will be lower than the theoretical value; ammonia could be found in the hydrogen stream and more than one borate may form. These have to be seen as outstanding issues.

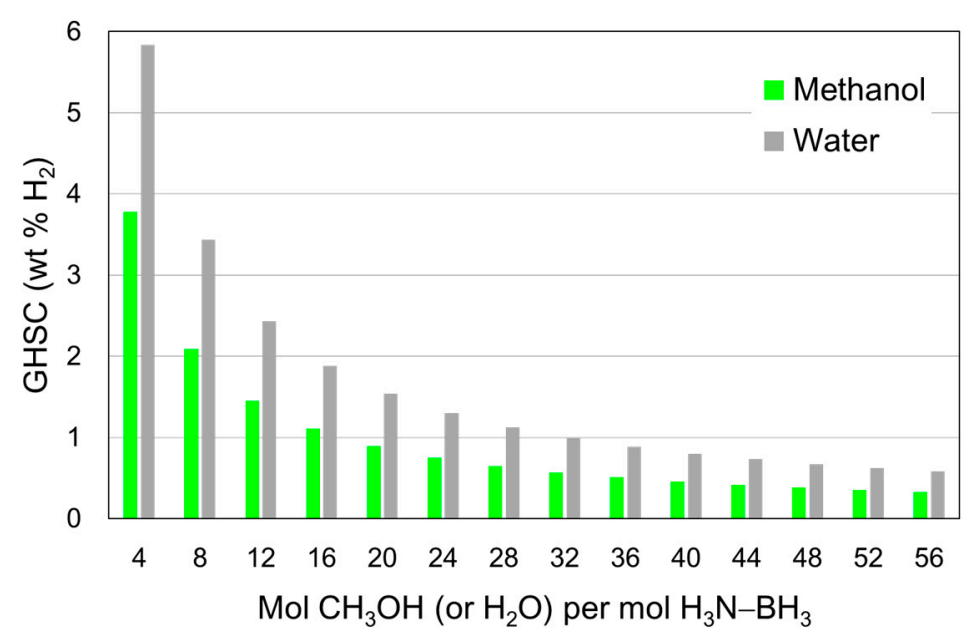

Figure 6. Evolution of the gravimetric hydrogen storage capacity (GHSC) of the couple ammonia borane-methanol as a function of the mole number of methanol per mole of ammonia borane. For comparison, the evolution for the couple ammonia borane-water is also shown.

The successful regeneration of ammonia borane using the ammonium tetramethoxyborate salt $\left[\mathrm{NH}_{4} \mathrm{~B}\left(\mathrm{OCH}_{3}\right)_{4}\right]_{5} \cdot 2 \mathrm{CH}_{3} \mathrm{OH}$ as reactant [37] has great appeal. The hydrogen cycle with the couple ammonia borane-methanol can be closed. More broadly, ammonia borane can be directly synthesized, namely without forming sodium borohydride in the first step, from another possible methanolysis product, which is trimethoxyborate $\mathrm{B}\left(\mathrm{OCH}_{3}\right)_{3}$. Indeed, Ramachandran et al. [168] developed a one-pot synthesis of ammonia borane, taking place in tetrahydrofuran at $0{ }^{\circ} \mathrm{C}$ :

$$
\mathrm{B}\left(\mathrm{OCH}_{3}\right)_{3}+\mathrm{NH}_{4} \mathrm{Cl}+\mathrm{LiAlH}_{4} \rightarrow \mathrm{H}_{3} \mathrm{~N}-\mathrm{BH}_{3}+\mathrm{Al}\left(\mathrm{OCH}_{3}\right)_{3}+\mathrm{LiCl}+\mathrm{H}_{2}
$$


These achievements are arguments in favor of the methanolysis reaction, for which the hydrogen cycle could be closed (Figure 7).

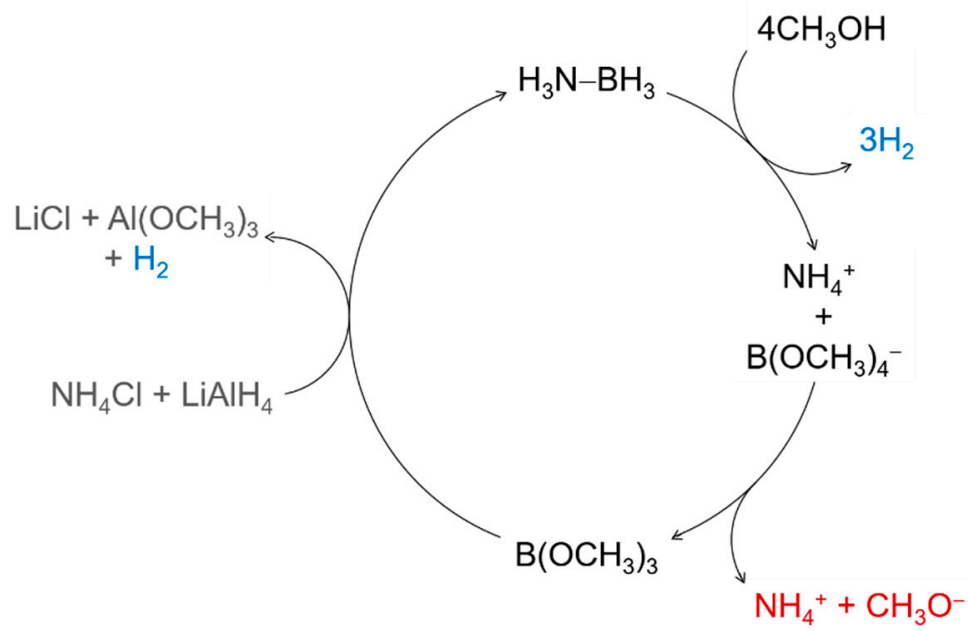

Figure 7. A way to close the hydrogen cycle with the couple ammonia borane-methanol, provided that a single by-product forms (Equation (17)).

\section{Ammonia Borane as a Solid-State Hydrogen Storage Material}

\subsection{Pristine Ammonia Borane}

Pure ammonia borane is stable at ambient conditions under inert atmosphere, for 13 to 72 days when kept at $50{ }^{\circ} \mathrm{C}[169]$, about 5.5 days at $60{ }^{\circ} \mathrm{C}$ [170] and only $3 \mathrm{~h}$ at $85^{\circ} \mathrm{C}$ [171]. At around $100{ }^{\circ} \mathrm{C}$, ammonia borane melts [172]. Above this temperature, it decomposes. However, the decomposition may start below $100{ }^{\circ} \mathrm{C}$, from about $70{ }^{\circ} \mathrm{C}$, when a very slow heating rate (e.g., $0.05^{\circ} \mathrm{C} \mathrm{min}-1$ ) is applied [173].

The decomposition path of ammonia borane is generally described in a fairly straightforward manner. The first step is the induction [174]. Ammonia borane, which becomes more mobile under heating [175], dimerizes into an ionic dimer, the diammoniate of diborane:

$$
2 \mathrm{H}_{3} \mathrm{~N}-\mathrm{BH}_{3} \rightarrow\left[\mathrm{NH}_{3} \mathrm{BH}_{2} \mathrm{NH}_{3}\right]^{+}\left[\mathrm{BH}_{4}\right]^{-}
$$

The diammoniate of diborane is the reactive species, the one decomposing. It is more reactive than ammonia borane. The decomposition is then stepwise.

From the diammoniate of diborane, which reacts with an additional ammonia borane molecule, the first equivalent of hydrogen is generated. This can be illustrated as follows:

$$
\left[\mathrm{NH}_{3} \mathrm{BH}_{2} \mathrm{NH}_{3}\right]^{+}\left[\mathrm{BH}_{4}\right]^{-}+\mathrm{H}_{3} \mathrm{~N}-\mathrm{BH}_{3} \rightarrow \mathrm{H}_{3} \mathrm{~N}-\left(\mathrm{BH}_{2}-\mathrm{NH}_{2}\right)_{2}-\mathrm{BH}_{3}+2 \mathrm{H}_{2}
$$

It is important to point out that the reaction is generally reported in the open literature as follows [176]:

$$
n \mathrm{H}_{3} \mathrm{~N}-\mathrm{BH}_{3} \rightarrow\left[-\mathrm{BH}_{2}-\mathrm{NH}_{2}-\right]_{n}+n \mathrm{H}_{2}
$$

Ammonia borane transforms into polyaminoborane (non-crystalline) and hydrogen by dehydrocoupling. However, gaseous by-products like aminoborane $\mathrm{H}_{2} \mathrm{~N}=\mathrm{BH}_{2}$, diborane $\mathrm{B}_{2} \mathrm{H}_{6}$, ammonia $\mathrm{NH}_{3}$ and/or borazine $\mathrm{B}_{3} \mathrm{~N}_{3} \mathrm{H}_{6}$ are also generated (Figure 8) [177]. This first decomposition step is exothermic, with an enthalpy of e.g., $-21 \mathrm{~kJ} \mathrm{~mol}^{-1}$ [178]. 


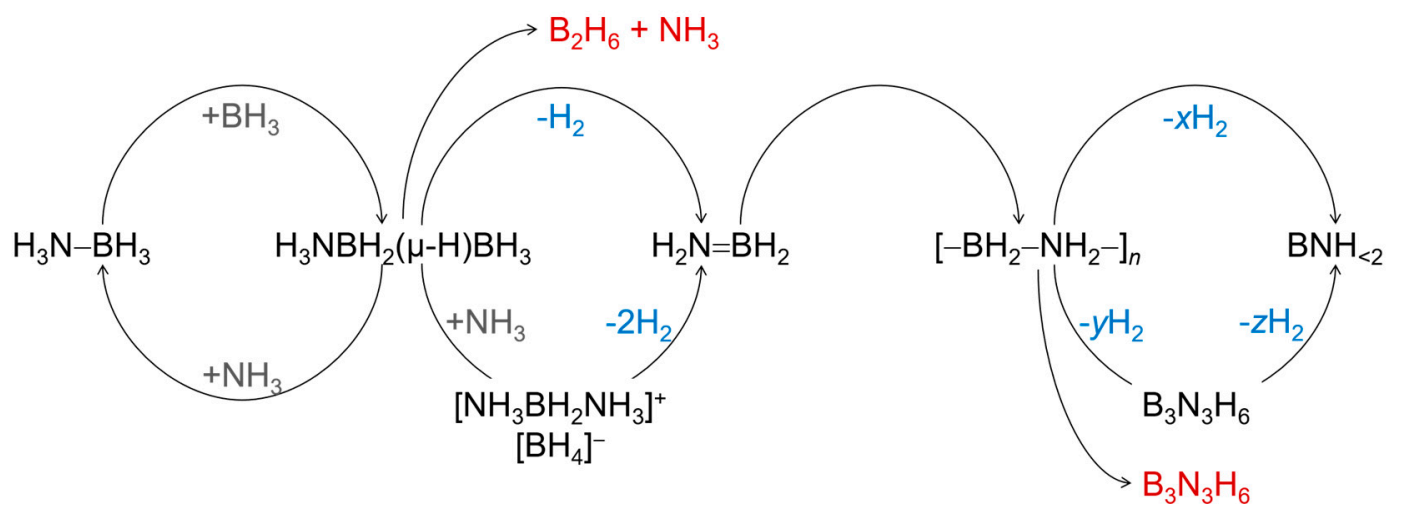

Figure 8. A possible mechanism of the thermolytic decomposition of ammonia borane, as suggested in reference [177]. Non-crystalline polyaminoborane and polyborazylene are represented by $\left[-\mathrm{BH}_{2}-\mathrm{NH}_{2}-\right]_{\mathrm{n}}$ and $\mathrm{BNH}_{<2}$.

The second step of the ammonia borane decomposition, taking place above $120-130{ }^{\circ} \mathrm{C}$ [172], generates borazine as the main product [179]. The second equivalent of hydrogen is also generated:

$$
\left[-\mathrm{BH}_{2}-\mathrm{NH}_{2}-\right]_{n} \rightarrow[-\mathrm{BH}=\mathrm{NH}-]_{n}+n \mathrm{H}_{2}
$$

According to this reaction, polyiminoborane $[-\mathrm{BH}=\mathrm{NH}-]_{n}$ forms. The aforementioned two steps take place at temperatures lower than $200^{\circ} \mathrm{C}$.

The third equivalent of hydrogen is generated above $200^{\circ} \mathrm{C}$. The total release of it requires high temperatures, well beyond $500{ }^{\circ} \mathrm{C}$, and this results boron nitride $\mathrm{BN}$ forming (semi-crystalline above $\left.1170^{\circ} \mathrm{C}\right)[180]$ :

$$
\left[-\mathrm{BH}_{2}-\mathrm{NH}_{2}-\right]_{n} \rightarrow[\mathrm{BN}]_{n}+n \mathrm{H}_{2}
$$

Boron nitride is a highly stable ceramic, and its rehydrogenation is thermodynamically impossible in affordable conditions (in terms of temperature and pressure of $\mathrm{H}_{2}$ ). The dehydrogenation of ammonia borane thus has to be restricted to about two equivalents of hydrogen to avoid the formation of boron nitride.

The decomposition is in fact more complex than the simplistic chain-growth polymerization path (Equations (21) and (22)) based on heteropolar dihydrogen $\mathrm{N}-\mathrm{H}^{\delta+} \ldots \mathrm{H}^{\delta-}-\mathrm{B}$ interactions and the head-to-tail dehydrocoupling of ammonia borane (Figure 9a). Basically, this path does not rationalize the release of the unwanted gaseous products like diborane and the formation of a polymeric residue with tri- and tetra-coordinated boron atoms, thus being more complex than the aforementioned linear polymers [181]. Wolstenholme et al. [182] and Roy et al. [183] showed the existence of counterintuitive homopolar dihydrogen $\mathrm{B}-\mathrm{H}^{\delta-} \ldots \mathrm{H}^{\delta-}-\mathrm{B}$ interactions (Figure 9b). Petit and Demirci [184] reported homopolar dihydrogen $\mathrm{N}-\mathrm{H}^{\delta+} \ldots \mathrm{H}^{\delta+}-\mathrm{N}$ interactions noticeably contributing to hydrogen release. Al-Kukhun et al. [177] showed that the $\mathrm{BH}_{3}$ group of ammonia borane makes a superior contribution to the release of hydrogen than the $\mathrm{NH}_{3}$ group, and that the heteropolar and homopolar interactions have comparable contributions. Otherwise, Petit et al. [185] analyzed the polymeric products forming upon the evolution of one equivalent of hydrogen from two different ammonia boranes, and found that all of the molecules do not simultaneously decompose and polymerize (Figure 10). The polymeric products were found to be composed of various molecular structures, suggesting a mixture of polyaminoborane, polyiminoborane and polyborazylene, in good agreement with Summerscales and Gordon's observations [186]. In other words, various reaction pathways, which are intra- and inter-molecular, take place during the two-step decomposition of ammonia borane, up to about $200{ }^{\circ} \mathrm{C}$ [187]. It results in a polymeric residue generally denoted as $\mathrm{BNH}_{x}\left(\right.$ with $x<2$ ) or $\mathrm{BNH}_{<2}$. 
(a)

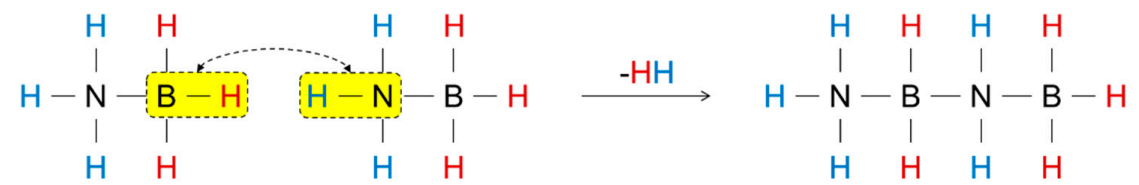

(b)
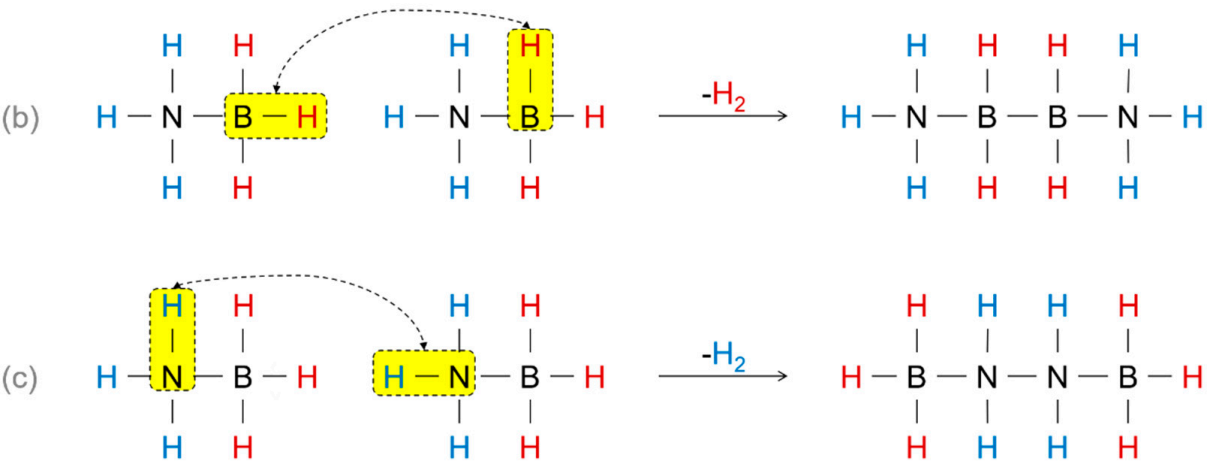

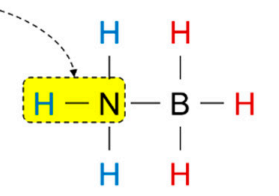

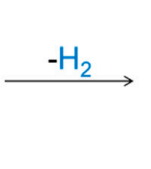

Figure 9. Dehydrocoupling of ammonia borane mediated by (a) heteropolar dihydrogen $\mathrm{N}-\mathrm{H}^{\delta+} \ldots \mathrm{H}^{\delta-}-\mathrm{B}$ interactions, (b) homopolar dihydrogen $\mathrm{B}-\mathrm{H}^{\delta-} \ldots \mathrm{H}^{\delta-}-\mathrm{B}$ interactions and (c) homopolar dihydrogen $\mathrm{N}-\mathrm{H}^{\delta+} \ldots \mathrm{H}^{\delta+}-\mathrm{N}$ interactions.

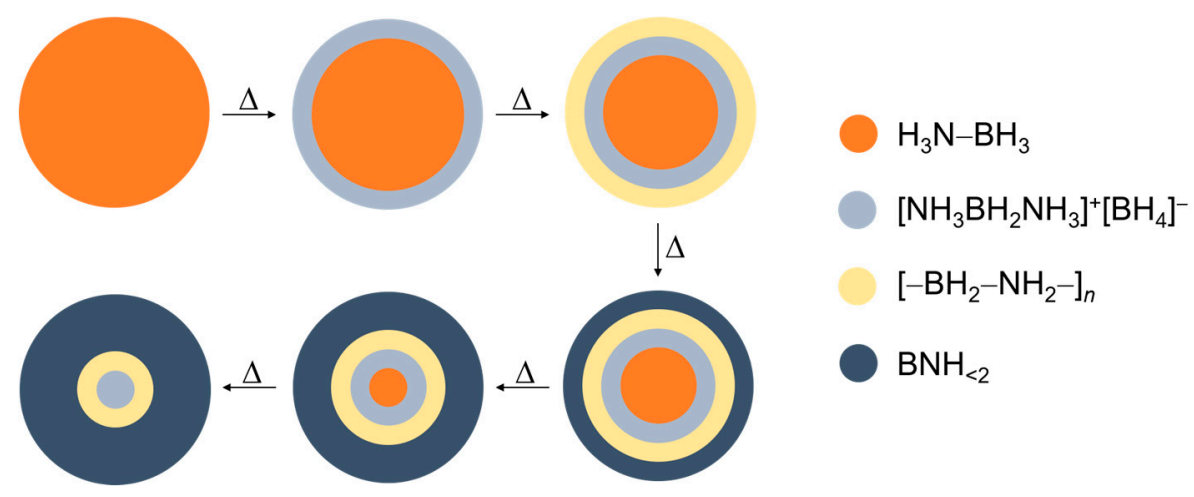

Figure 10. Illustration of the heterogenous decomposition of ammonia borane: all of the molecules would not simultaneously decompose and polymerize.

In summary, ammonia borane in a pristine state is not appropriate for hydrogen storage, and this is for four main reasons. Ammonia borane decomposes more than it dehydrogenates. The process takes place slowly at temperatures over $70{ }^{\circ} \mathrm{C}$ and more rapidly above $120{ }^{\circ} \mathrm{C}$. The decomposition (and the dehydrogenation) is exothermic. Accordingly, the rehydrogenation of the dehydrogenated form of ammonia borane requires energy to offset the heat lost (due to the exothermic breaking of $\mathrm{B}-\mathrm{H}$ and $\mathrm{N}-\mathrm{H}$ bonds). This suggests difficult, from a thermodynamic point of view, rehydrogenation at low temperature and under hydrogen pressure. This thus suggests the requirement of chemical rehydrogenation. The polymeric residue forming upon decomposition is of complex composition and not well identified, which makes the recycling approach tough.

It is in that context that strategies for destabilizing ammonia borane and making it suitable for hydrogen storage were introduced. There are four. They all aim at dehydrogenating ammonia borane rapidly, at temperatures below $100^{\circ} \mathrm{C}$ and with the formation of a single polymeric product.

\subsection{Ammonia Borane in an Aprotic Solvent}

With protic solvents, hydrolysis and alcoholysis take place, as discussed in the previous sections. With aprotic solvents, ammonia borane can be isolated as a molecule and the dihydrogen $\mathrm{N}-\mathrm{H}^{\delta+} \ldots \mathrm{H}^{\delta-}-\mathrm{B}$ interactions are disrupted. This makes dehydrogenation easier. 
Ammonia borane is soluble in ionic liquids. Bluhm et al. [171] investigated an equal weight mixture of ammonia borane and 1-butyl-3-methylimidazolium chloride (oversaturated solution), the solubility of the borane being $47.5 \mathrm{~g}$ in $100 \mathrm{~g}$ of solvent [188]. The mixture consisted of ammonia borane in both solubilized and solid states. Heated at $85^{\circ} \mathrm{C}$, the mixture released hydrogen immediately, showing no induction period (versus an induction time of about $3 \mathrm{~h}$ for the pristine borane). It released $1 \mathrm{~mol} \mathrm{H}_{2}$ per $\mathrm{mol} \mathrm{H}_{3} \mathrm{~N}-\mathrm{BH}_{3}$ in $67 \mathrm{~min}$ and $2.2 \mathrm{~mol} \mathrm{H}_{2}$ in $330 \mathrm{~min}$ [189]. Nakagawa et al. [188] reported that more than $2 \mathrm{~mol} \mathrm{H}_{2}$ per $\mathrm{mol} \mathrm{H}_{3} \mathrm{~N}-\mathrm{BH}_{3}$, with limited impurity emissions, can be released between 80 and $130{ }^{\circ} \mathrm{C}$, without any reaction between ammonia borane and 1-butyl-3-methylimidazolium chloride. Consistent results were reported elsewhere [190]. The ionic liquid was suggested to act as a promoter favoring the formation of the diammoniate of diborane. Upon dehydrogenation, neutral polyaminoborane and then unsaturated cross-linked polyborazylene were reported to form. Elsewhere, a complex solid solution was instead suggested [188]. Several other ionic liquids were reported in reference [189] and elsewhere [191-193], including 1-butyl-2,3-dimethylimidazolium chloride, 1-ethyl-2,3-dimethylimidazolium ethyl-sulfate, 1-butyl-3-methylimidazolium tetra-fluoroborate, 1-butyl-3-methylimidazolium triflate and 1-butyl-3-methylimidazolium hexafluorophosphate, among others. Beyond the works cited above, where the last dates back to 2015, the use of ionic liquids has not been further studied. One plausible explanation is the difficult extraction of the dehydrogenation products because of the high boiling point of the ionic liquids.

Ammonia borane is soluble in organic solvents. In triglyme, its solubility is $34.4 \mathrm{~g}$ in $100 \mathrm{~g}$ of solvent. Kostka et al. [194] studied solutions at various concentrations, from 0.1 to $6 \mathrm{~mol} \mathrm{~L}^{-1}$. Improved dehydrogenation properties were found, in comparison with the pristine ammonia borane. For instance, the solution at $6 \mathrm{~mol} \mathrm{~L}^{-1}$ generated $1 \mathrm{~mol} \mathrm{H}_{2}$ per $\mathrm{mol} \mathrm{H}_{3} \mathrm{~N}-\mathrm{BH}_{3}$ in less than $1 \mathrm{~h}$ at $70{ }^{\circ} \mathrm{C}$. There was no induction period, also for other solvents like glyme, diglyme and tetraglyme. Dehydrocoupling of ammonia borane in triglyme follows a complex path where, in addition to borazine, several cyclic products form (Figure 11), especially for high concentrations of ammonia borane. The cyclic products were suggested to be intermediates before the formation of borazine and then polyborazylene [195].

Ammonia borane, solubilized in an organic solvent, is able to generate pure hydrogen with good kinetics, provided that a (homogenous) catalyst is used. Denney et al. [196] reported an iridium pincer complex, denoted (POCOP $) \operatorname{Ir}(\mathrm{H})_{2}$ with POCOP as $\left[\eta^{3}-1,3-\left(\mathrm{OP}^{\mathrm{t}} \mathrm{Bu}_{2}\right)_{2} \mathrm{C}_{6} \mathrm{H}_{3}\right]$. The complex $(1 \mathrm{~mol} \%)$ was able to catalyze the dehydrocoupling of ammonia borane $\left(0.5 \mathrm{~mol} \mathrm{~L}^{-1}\right.$ in tetrahydrofuran) towards the release of one equivalent of hydrogen in less than $5 \mathrm{~min}$ at room temperature:

$$
5 \mathrm{H}_{3} \mathrm{~N}-\mathrm{BH}_{3} \rightarrow\left[\mathrm{H}_{2} \mathrm{~N}-\mathrm{BH}_{2}\right]_{5}+5 \mathrm{H}_{2}
$$

The oligomeric product precipitated. Another iridium complex, $\left[\mathrm{Ir}(\mathrm{H})_{2}(\mathrm{dppm})_{2}\right] \mathrm{OTf}$, was reported elsewhere [197]. Keaton et al. [198] investigated a N-heterocyclic carbene nickel complex for dehydrogenating ammonia borane $(25 \mathrm{wt} \%)$ in diglyme at $60{ }^{\circ} \mathrm{C}$. A small amount of the complex ( $1 \mathrm{~mol} \%)$ was able to catalyze the rapid dehydrogenation of ammonia borane to a high extent (ca. $2.8 \mathrm{~mol} \mathrm{H}_{2}$ per $\mathrm{mol} \mathrm{H}_{3} \mathrm{~N}-\mathrm{BH}_{3}$ ) in less than $4 \mathrm{~h}$. Conley and Williams [199] developed a Shvo's cyclopentadienone-ligated ruthenium complex that catalyzed the generation of two equivalents of hydrogen and the formation of borazine from ammonia borane in a mixture of diglyme and benzene, at $70{ }^{\circ} \mathrm{C}$ :

$$
3 \mathrm{H}_{3} \mathrm{~N}-\mathrm{BH}_{3} \rightarrow \mathrm{B}_{3} \mathrm{~N}_{3} \mathrm{H}_{6}+3 \mathrm{H}_{2}
$$

Afterwards, iron [200,201], ruthenium [202-204] and palladium complexes [205,206] were reported as possible efficient homogeneous catalysts for dehydrogenating ammonia borane in solution. Details about all of the homogeneous catalysts reported above are available in several review papers authored by active researchers in the field [207-209]. Recently, Hasenbeck et al. [210] reported a metal-free organocatalyst, the 6-tert-butyl-2-thiopyriperformed. At a concentration of $1 \mathrm{~mol} \%$, it was able to dehydrogenate ammonia borane at reflux in tetrahydrofuran in $2 \mathrm{~h}$ (Equation (25)). A turnover frequency of $88 \mathrm{~h}^{-1}$ was achieved. 
The dehydrocoupling of ammonia borane in an organic solvent and in the presence of a homogenous catalyst offers some advantages, such as a simple dehydrogenation pathway resulting in a single product like borazine or polyborazylene, the release of pure hydrogen (apart from the solvent), faster hydrogen release kinetics in comparison to the uncatalyzed reaction and temperatures of reaction lower than $100^{\circ} \mathrm{C}$ (e.g., at ambient conditions). However, there are also drawbacks, which are significant barriers to the technological implementation of this destabilization strategy, namely: the vapor pressure of the organic solvents that inevitably pollutes the hydrogen stream; the homogenous nature of the catalyst that makes its extraction from the reaction slurry tough; the limited cyclability of the catalyst; and the low solubility of ammonia borane in the mentioned solvents, which negatively impact the effective gravimetric hydrogen storage capacities (Figure 12). Using a liquid hydrogen fuel resembling gasoline has appeal, and it is regrettable that this liquid ammonia borane approach has not been scaled up yet. This would have allowed a better understanding of the advantages and drawbacks of it.

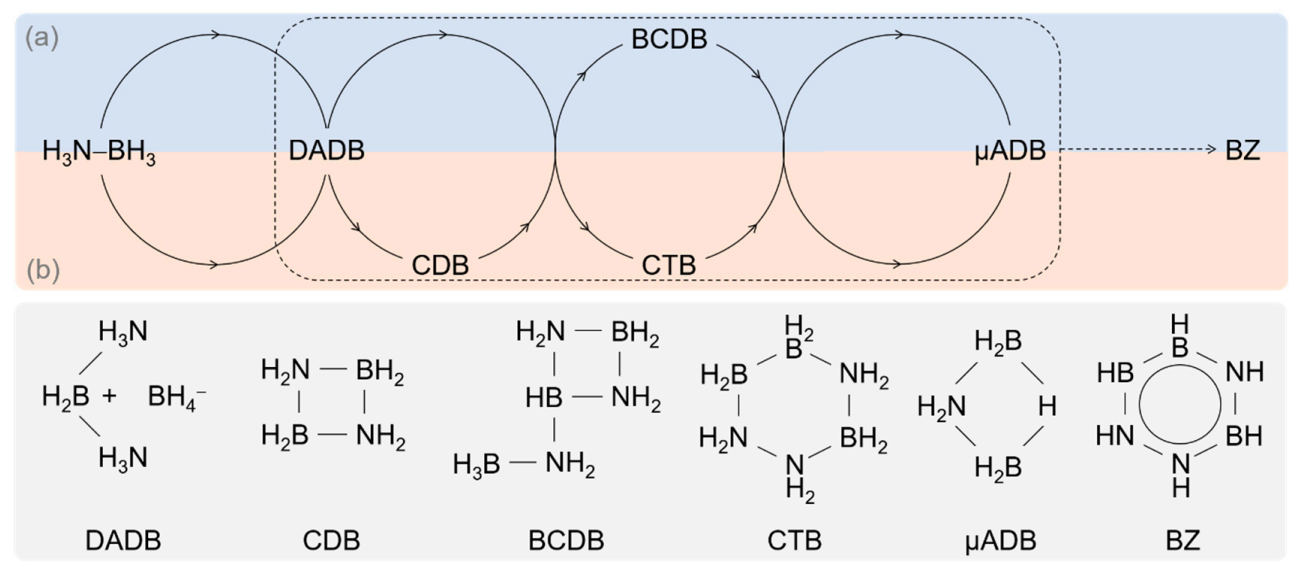

Figure 11. Proposed thermolytic dehydrogenation pathways of ammonia borane in triglyme: (a) for high concentrations of ammonia borane, (b) for low concentrations of ammonia borane. With DADB for diammoniate of diborane, CDB for cyclodiborazane, BCDB for B-(cyclodiborazanyl)aminoborohydride, CTB for cyclotriborazane, $\mu$ ADB for $\mu$-aminodiborane and BZ for borazine. Adapted from ref. [194].

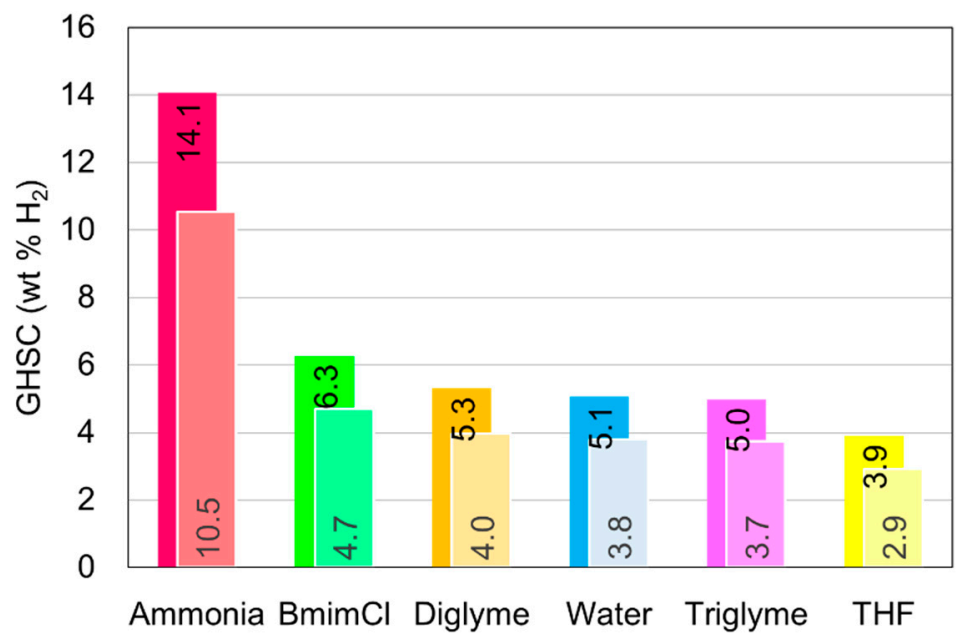

Figure 12. Gravimetric hydrogen storage capacity (GHSC) of ammonia borane in liquid ammonia, the ionic liquid 1-butyl-3-methylimidazolium chloride $(\mathrm{BmimCl})$, diglyme, water, triglyme and tetrahydrofuran (THF). The solubility limit of ammonia borane in $100 \mathrm{~g}$ of these solvents is 259.7, $47.5,37.4,35.1,34.4$ and $25 \mathrm{~g}$ respectively. With respect to the bars with no border, the capacity is based on $100 \%$ of the hydrogens of ammonia borane. For the bars with the white borders, it is assumed that $75 \%$ of the hydrogen of ammonia borane can be released. The capacities (in $\mathrm{wt} \% \mathrm{H}_{2}$ ) are all given. 


\subsection{Chemical Doping of Solid Ammonia Borane}

By adding a chemical dopant, solid mixtures made of ammonia borane as the main component can be obtained. The first mixture was proposed by Benedetto et al. [211]. They showed that the addition of 1-2 mol\% of platinum, in the form of hexachloroplatinic salt, resulted in improved dehydrogenation properties, with a significantly reduced induction period and faster kinetics. Upon reaction, reduced platinum was recovered, but no analyses were performed with regard to the purity of the released hydrogen and the nature of the polymeric residue. The positive effect of a dopant on the induction period of ammonia borane was later confirmed by Heldebrant et al. [175]. The period was measured to be as long as about $6 \mathrm{~h}$ for pristine ammonia borane at $80^{\circ} \mathrm{C}$, whereas the addition of ammonium chloride $(5 \mathrm{wt} \%)$ resulted in the absence of an induction period. A series of chlorides were afterwards considered to be possible dopants. He et al. [212] tested nickel chloride $\mathrm{NiCl}_{2}$ and cobalt chloride $\mathrm{CoCl}_{2}$ (for both $2 \mathrm{~mol} \%$ ). Ammonia borane was destabilized, liberating hydrogen (and no borazine) at $59^{\circ} \mathrm{C}$ and upwards. Benzouaa et al. [213] worked with cobalt chloride $\mathrm{CoCl}_{2}$, iron chloride $\mathrm{FeCl}_{3}$ and aluminum chloride $\mathrm{AlCl}_{3}$. They all destabilized ammonia borane, which featured decreased onset temperatures of decomposition $\left(52,65\right.$ and $85^{\circ} \mathrm{C}$ respectively, versus $99^{\circ} \mathrm{C}$ for the pristine ammonia borane, the last temperature being typical of an ammonia borane sample with a purity higher than $97 \%$ and of an experiment performed at a heating rate of $5^{\circ} \mathrm{C} \mathrm{min}^{-1}$ ). Reduced induction periods and much less borazine were noticed when, for example, cobalt chloride was used. Better results were reported for copper chloride [214,215]. Despite improved decomposition properties, doping with metal chlorides does not totally prevent the formation of borazine, and the polymeric residue formed is of complex composition [213-216]. The metal cation $\mathrm{Cu}^{2+}$ of copper chloride plays a Lewis acid role, destabilizing the $\mathrm{B}-\mathrm{N}$ bond of ammonia borane through the formation of a reactive intermediate, such as $\mathrm{Cu} \cdots \mathrm{NH}_{2}-\mathrm{BH}_{2}$, then facilitating the head-to-tail dehydrocoupling of ammonia borane. Comparable results were reported for magnesium and calcium chlorides [217]. In the presence of the former, ammonia borane dehydrogenated purely, starting from $40{ }^{\circ} \mathrm{C}$, whereas traces of ammonia were detected when ammonia borane was doped with the latter halide. The release of ammonia was also reported for ammonia borane doped with potassium bromide [218]. The additive was found to favor the formation of diammoniate of diborane as well as the formation of ammonium ions that catalyzed the dehydrogenation of ammonia borane. Overall, the addition of metal halide has positive effects, but the evolution of gaseous by-products is not totally suppressed. It is also unclear what the nature of the polymeric residue and the post-thermolysis state of the chemical additive are.

Metal hydrides are also possible dopants. Note that the mixtures made of one mole of ammonia borane and one mole of another hydride, which are actually composites, are out of the scope of the present work. In such composites, the addition of the hydride cannot be seen as a simple destabilization of ammonia borane. The composites have to be considered to be new materials.

Kang et al. [219] demonstrated the positive effect of magnesium hydride $\mathrm{MgH}_{2}$ as a chemical additive. The milled mixture, consisting of $1 \mathrm{~mol} \mathrm{H}_{3} \mathrm{~N}-\mathrm{BH}_{3}$ and $0.5 \mathrm{~mol} \mathrm{MgH}_{2}$, showed an apparent activation energy of $66 \mathrm{~kJ} \mathrm{~mol}^{-1}$ for the release of one equivalent of hydrogen (versus $183 \mathrm{~kJ} \mathrm{~mol}^{-1}$ for pristine ammonia borane). Up to $200^{\circ} \mathrm{C}$, it released around 1.9 equivalents of hydrogen:

$$
\mathrm{H}_{3} \mathrm{~N}-\mathrm{BH}_{3} \rightarrow \mathrm{BNH}_{2.2}+1.9 \mathrm{H}_{2}
$$

A fraction of magnesium hydride was suggested to participate in the dehydrogenation process via the formation of Mg-B-N-H intermediate species [220]. Tang et al. [221] used magnesium-nickel hydride $\mathrm{Mg}_{2} \mathrm{NiH}_{4}$ (1 mol) to destabilize ammonia borane (4 mol). Pure hydrogen (two equivalents) was released, according to a two-step process occurring at 50 and $110{ }^{\circ} \mathrm{C}$ (one equivalent for each step). Improved dehydrogenation properties were also reported for other double cation hydrides, such as $\mathrm{NaMgH}_{3}, \mathrm{KMgH}_{3}$ and $\mathrm{RbMgH}_{3}$ [222]. Choi et al. [223] compared magnesium hydride $\mathrm{MgH}_{2}$, titanium hydride $\mathrm{TiH}_{2}$, zirconium hydride $\mathrm{ZrH}_{2}$ and calcium hydride $\mathrm{CaH}_{2}$. Doping $2 \mathrm{~mol}$ $\mathrm{H}_{3} \mathrm{~N}-\mathrm{BH}_{3}$ with $1 \mathrm{~mol} \mathrm{MgH}$ and $0.1 \mathrm{~mol} \mathrm{TiH}$ was found to be efficient in lowering the dehydrogenation 
temperature of ammonia borane. Kobayashi et al. [224] showed that lithium alanate $\mathrm{Li}_{3} \mathrm{AlH}_{6}$ improves the dehydrogenation kinetics of ammonia borane (for a 1:3 mixture) via the formation of an intermediate containing lithium amidoborane $\mathrm{LiNH}_{2} \mathrm{BH}_{3}$. Wan et al. [225] destabilized ammonia borane (3 mol) by using aluminum hydride $\mathrm{AlH}_{3}(1 \mathrm{~mol})$. The release of more than $12 \mathrm{wt} \%$ of pure hydrogen was measured up to $250{ }^{\circ} \mathrm{C}$. Ammonia borane was destabilized by Coulombic attraction between $\mathrm{H}^{\delta+}$ of $\mathrm{NH}_{3}$ of ammonia borane and $\mathrm{H}^{\delta-}$ of $\mathrm{AlH}_{3}$. With more reactive metal hydrides like sodium hydride $\mathrm{NaH}$, chemical doping is not relevant because a derivative of ammonia borane forms. This is discussed hereafter, in Section 5.5, which is dedicated to amidoboranes.

Other chemical dopants have been reported so far. Neiner et al. [226,227] used pre-milled hexagonal boron nitride. The dopant showed a slight beneficial effect by favoring the disruption of the dihydrogen $\mathrm{N}-\mathrm{H}^{\delta+} \ldots \mathrm{H}^{\delta-}-\mathrm{B}$ interactions in ammonia borane, but it also had a negative impact, by promoting the formation of borazine by a surface-enhanced mechanism. Pre-milling boron nitride was important to obtain nanocrystallites of about $10 \mathrm{~nm}$, thereby developing a higher specific surface area of $251 \mathrm{~m}^{2} \mathrm{~g}^{-1}$ than the bulk counterpart $\left(12 \mathrm{~m}^{2} \mathrm{~g}^{-1}\right)$. The chemical dopant destabilization strategy is based on grain-to-grain contact between the dopant and ammonia borane, and nanosizing the dopant allows increased contacts. In this way, elsewhere, silicon [228], silica [229] and nickel [230] were used in the form of nanosized dopants.

Some of the studied dopants contain oxygen and protic hydrogen. This is a paradox, because it is like protonolysis (comparable to hydrolysis or methanolysis), and stable B-O bonds are likely to form. A first example of an oxygen-containing dopant is boric acid $\mathrm{B}(\mathrm{OH})_{3}$. Hwang and Varma [231] demonstrated its positive effect on the thermolysis of ammonia borane. For example, more than two equivalents of hydrogen were released at $85^{\circ} \mathrm{C}$, and only trace amount of ammonia $(<30 \mathrm{ppm})$ was detected. The involvement of the tetrahydroxyborate ion $\mathrm{B}(\mathrm{OH})_{4}{ }^{-}$and water was noticed. However, surprisingly, the polymeric residue was suggested to be a polyborazylene-like species, with no mention of likely B-O bonds. Ergüven et al. [232] explained the role of boric acid as that of a Lewis acid (versus a Lewis base for ammonia borane). Shin et al. [233] destabilized ammonia borane with mucic acid, a dicarboxylic acid with the formula $\mathrm{C}_{6} \mathrm{H}_{10} \mathrm{O}_{8}$. The 8:2 mixture produced pure $\mathrm{H}_{2}$ $(10.8 \mathrm{wt} \%)$ at $80{ }^{\circ} \mathrm{C}$ in $1 \mathrm{~min}$. This performance is attractive. Similar attractive results were reported by Kim et al. [234], who used D-mannitol $\mathrm{C}_{6} \mathrm{H}_{14} \mathrm{O}_{6}$, an alcohol with six $\mathrm{OH}$ groups, as a dopant. In both works, the polymeric residue was made of $\mathrm{B}-\mathrm{O}$ bonds. This raises the question: is such an approach more attractive than hydrolysis, which allows the generation of a lot hydrogen at $20^{\circ} \mathrm{C}$, and with faster kinetics?

There are also protic hydrogen-free oxygen-containing dopants. Kim et al. [235,236] investigated polyetheral additives like tetraethylene glycol dimethyl ether $\mathrm{C}_{10} \mathrm{H}_{22} \mathrm{O}_{5}$, which enhanced the rate of hydrogen generation from ammonia borane under heating (e.g., $125^{\circ} \mathrm{C}$ ). It, however, did not hinder the formation of unwanted gaseous products like borazine. The great thing about Kim et al.'s works is that they pushed the logic to the extreme [237]. They constructed a hydrogen generator based on ammonia borane and the aforementioned additive, with the generator integrating a 200 We polymer electrolyte membrane fuel cell (Figure 13). Under operation, a hydrogen generation rate as high as 3.3 $\mathrm{L} \mathrm{min}^{-1}$ was reached, being enough to operate the fuel cell for $25 \mathrm{~min}$ with $58 \mathrm{~g}$ of ammonia borane. A purifying system (i.e., acidic active carbons trapping borazine) allowed the feeding of the fuel cell with pure hydrogen. This demonstrator was the first one ever reported with ammonia borane as a hydrogen carrier. 

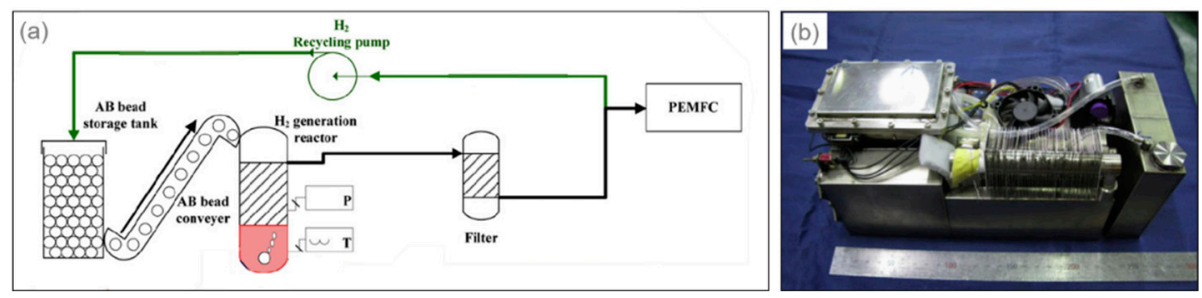

Figure 13. Hydrogen generator developed by Kim et al. [237]. (a) A process flow diagram of the continuous hydrogen generator from ammonia borane: the ammonia borane beads are conveyed into the tetraethylene glycol dimethyl ether-containing reactor; the generated hydrogen is filtered and then it feeds a polymer electrolyte membrane fuel cell (PEMFC); the excess of hydrogen is recycled. (b) Photography of the hydrogen generator. Reprinted from ref. [237], Copyright (2013), with permission from Elsevier.

The addition of a chemical dopant results in the destabilization of ammonia borane, which releases hydrogen at temperatures below $100{ }^{\circ} \mathrm{C}$ and with faster kinetics. The destabilization is even, in some cases, too effective, leading to the ammonia borane being unstable at ambient temperature. The released hydrogen is purer than the hydrogen generated by pristine ammonia borane, but the chemical dopant does not seem to be efficient enough to suppress the formation of any gaseous by-product. The purity of the released hydrogen is, however, not clearly specified, and is globally controversial. The main limitation is inherent to the destabilization strategy itself, which is based on grain-to-grain contacts. The most efficient destabilization could be expected from the smallest grains, namely, at the nanoscale. Another critical issue with the doping strategy concerns the residue recovered upon dehydrogenation. Globally, very little is known about the state of the chemical dopant, and the nature of the polymeric residue is rather complex, though it is claimed to be polyborazylene-like in some instances. This also leads to substantial uncertainties in how to separate the dopant from the polymeric residue and then recycle all of the products. Recycling is a critical issue. This is discussed in Section 5.6 for the polymeric residue, but it is important to notice here that the presence of $\mathrm{B}-\mathrm{O}$ bonds in the polymeric residue makes the recycling more complicated. If this destabilization strategy should be further investigated, because it is the best for obtaining highly effective gravimetric hydrogen storage capacities (Figure 14), efforts should be focused on nano-engineering.

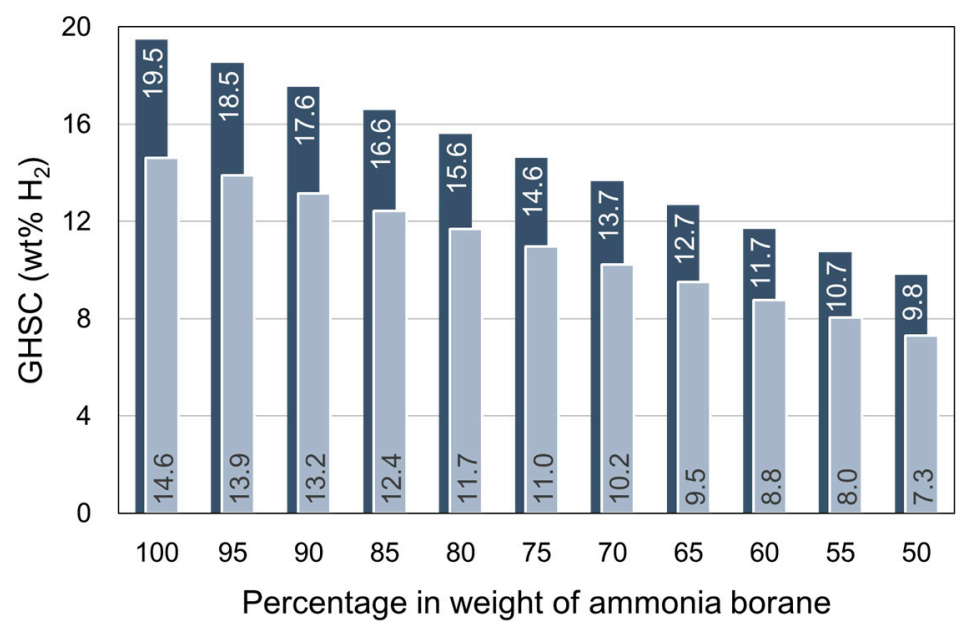

Figure 14. Gravimetric hydrogen storage capacity (GHSC) of ammonia borane (100 to $50 \%$ weight) mixed with a chemical dopant ( 0 to $50 \%$ in weight). With respect to the bars with no border, the capacity is based on $100 \%$ on the hydrogens of ammonia borane. For the bars with the white borders, it is assumed that $75 \%$ of the hydrogen of ammonia borane can be released. The capacities (in $w \mathrm{t} \% \mathrm{H}_{2}$ ) are all given. 


\subsection{Nanoconfinement of Ammonia Borane}

By infiltrating ammonia borane into the porosity of a scaffold, it is nanosized, and nanosized ammonia borane (also called ammonia borane nanophase) is able to show modified decomposition properties, with dehydrogenation being greatly favored. This is the nanoconfinement strategy [238-241].

The first work dealing with the nanoconfinement of ammonia borane used silica SBA-15 (specific surface area of $900 \mathrm{~m}^{2} \mathrm{~g}^{-1}$ ) as a scaffold. Gutowska et al. [23] infiltrated by capillary action the mesoporosity of the silica SBA-15 using a saturated methanolic solution of ammonia borane. In doing so, AB@SBA-15, consisting in $50 \mathrm{wt} \%$ of ammonia borane and showing a specific surface area below $50 \mathrm{~m}^{2} \mathrm{~g}^{-1}$, was produced. AB@SBA-15 showed attractive dehydrogenation properties by releasing hydrogen from $50{ }^{\circ} \mathrm{C}$. Moreover, the enthalpy of hydrogen release was measured as $-1 \mathrm{~kJ} \mathrm{~mol}^{-1}$, suggesting an almost neutral process. Comparable improved dehydrogenation properties were reported for mesoporous silica MCM-41 [242-244], silica hollow nanospheres [245] and silica aerogel [246]. Note that the infiltration of $\mathrm{AB}$ is feasible with another suitable solvent, i.e., tetrahydrofuran [247], but the most important aspect is to avoid the presence of ammonia borane outside the porosity, because non-confined ammonia borane (also called an excess of ammonia borane) forms aggregates outside the scaffold porosity and behaves like pristine ammonia borane [248,249]. With silica as the scaffold, the purity of the released $\mathrm{H}_{2}$ is debated. It was found to be pure [250] or not (due to the formation of borazine and ammonia) [23,242].

There are three effects to explain the better dehydrogenation properties of the ammonia borane nanophase (Figure 15). First, the reduction of the size of the ammonia borane particles results in more defect sites (i.e., active sites initiating the dehydrogenation process) $[243,250]$ and in reduced diffusion distances (facilitating the release of hydrogen) [251]. Second, the hydrogens $\mathrm{H}^{\delta+}$ of the surface $\mathrm{SiO}-\mathrm{H}$ groups catalytically activate ammonia borane through dihydrogen $\mathrm{O}-\mathrm{H}^{\delta+} \ldots \mathrm{H}^{\delta-}-\mathrm{B}$ interactions [252], resulting in an acid-base reaction between $\mathrm{SiO}-\mathrm{H}$ and $\mathrm{BH}_{3}$ and the formation of surface $\mathrm{SiO}-\mathrm{B}$ groups [245]:

$$
\mathrm{H}_{3} \mathrm{~N}-\mathrm{BH}_{3}+\mathrm{SiO}-\mathrm{H}+\rightarrow \mathrm{H}_{3} \mathrm{~N}-\mathrm{BH}_{2}-\mathrm{OSi}+\mathrm{H}_{2}
$$

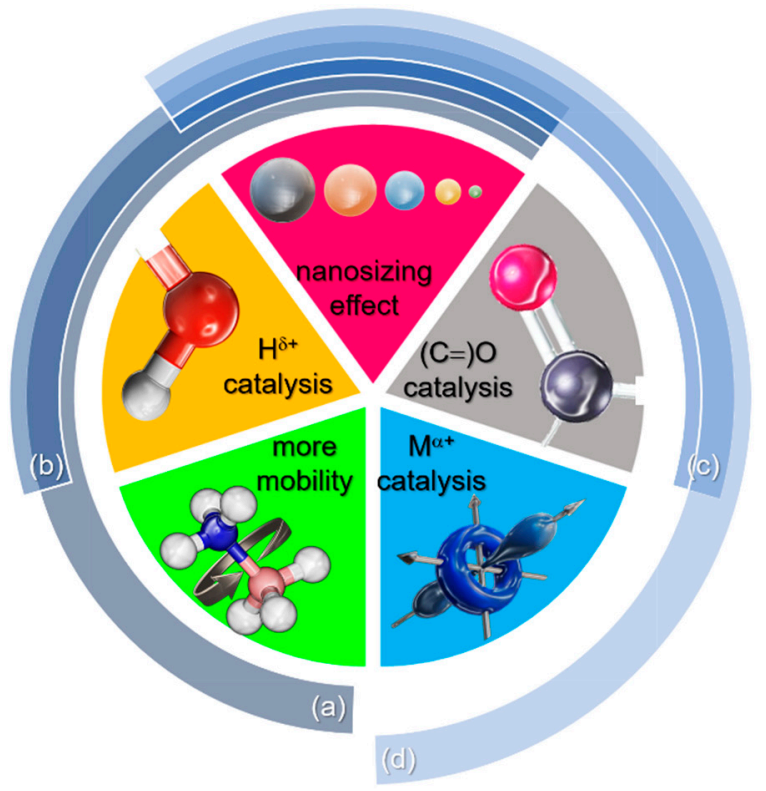
(a) Porous silica
(b) Porous carbonaceous materials
(c) Polymers
(d) Metal organic frameworks

Figure 15. Ammonia borane nanoconfinement into scaffolds: the destabilization effects.

Third, the ammonia borane nanophase is amorphous and, accordingly, it has an altered dihydrogen $\mathrm{N}-\mathrm{H}^{\delta+\ldots} \mathrm{H}^{\delta-}-\mathrm{B}$ network [253], and more mobile and active molecules [174]. 
Porous carbon is also a potential scaffold of ammonia borane. Improved dehydrogenation properties for ammonia borane were reported for carbon cryogels [254,255], activated carbon [256,257], mesoporous carbon CMK-3 [258], microporous carbon [259] and N-containing carbon nanotubes [260]. The positive effects described for the silica scaffolds are valid for the carbon scaffolds (Figure 15). First, Tang et al. [261] clearly showed that nanoparticles with a diameter of $4 \mathrm{~nm}$ were able to dehydrogenate starting from $50^{\circ} \mathrm{C}$, whereas larger nanoparticles (diameter of $10 \mathrm{~nm}$ ) dehydrogenated from $67^{\circ} \mathrm{C}$. So et al. [262] showed that the dehydrogenation of ammonia borane could be tuned by controlling the scaffold pore size in such a way that the narrower the pore size is, the lower the peak temperature of the $\mathrm{H}_{2}$ release. In other words, microporosity (a pore size of $<2 \mathrm{~nm}$ ) should be favored [263]. Second, the surface $\mathrm{COO}-\mathrm{H}(\mathrm{and} / \mathrm{or} \mathrm{CO}-\mathrm{H})$ groups provide acidic hydrogens $\mathrm{H}^{\delta+}$ that destabilize the ammonia borane molecules by acid-base reactions, even at temperatures as low as 3-4 ${ }^{\circ} \mathrm{C}$ [256], which indicates that this effect overpasses the nanosizing effect. This is interpreted as catalytic activation (i.e., acid catalysis) [264]. This was evidenced by the detection of CO-B and COO-B bonds in the materials upon dehydrogenation $[265,266]$. The catalytic activation, however, does not hinder the formation and release of ammonia [267].

Metal organic frameworks (MOFs) have also been designated as potential scaffolds of ammonia borane. The first ever reported for that purpose was water-free JUC-32-Y, made of unsaturated $\mathrm{Y}^{3+}$ metal sites and 1,3,5-benzenetricarboxylate rigid linkers [268]. Ammonia borane was infiltrated by capillary action and the as-obtained nanophase released hydrogen from $50{ }^{\circ} \mathrm{C}$, with the peak temperature of the dehydrogenation being $84^{\circ} \mathrm{C}$. Onset temperatures of dehydrogenation lower than $70{ }^{\circ} \mathrm{C}$ were reported for a series of MOFs, such as Mg-MOF-74 [269], Zn-MOF-74 [270], MIL-101 [271] and MOF-5 [272]. This was explained by the nanosizing effect [273]. Better yet, Chung et al. [274] showed a linear relationship between the temperature of hydrogen release and the reciprocal of the particle size of the ammonia borane nanophase (Figure 16). On the other hand, Jeong et al. [272] stressed on the importance of using MOFs with small pores. Geometric hindrance caused by the small pores was suggested to prevent the formation of borazine. In fact, it is believed that a large surface area and porosity are essential to avoid the formation of borazine [275]. Another effect, which is catalytic, was suggested [276-279]. The unsaturated metals of the MOFs are believed to act as Lewis acid sites, favoring the destabilization of ammonia borane through $\mathrm{M}^{\alpha+} \ldots \mathrm{NH}_{3}-\mathrm{BH}_{3}$ interactions. For example, the formation of $\mathrm{Fe}-\mathrm{NH}_{2}$ groups was identified for ammonia borane confined into Fe-MIL-5 upon dehydrogenation [270]. With saturated metal sites, ammonia was produced because of a less efficient catalytic effect $[271,274,275]$. Another catalytic effect (Figure 15), due to the O-functional groups (belonging to the linkers) of the MOFs, was suggested to take place together with the previous catalytic effect. These groups interact with the $\mathrm{BH}_{3}$ group of ammonia borane, thereby destabilizing the B-H and B-N bonds. Srinivas et al. $[270,277]$ gave evidence of this, via the formation of B-O bonds upon dehydrogenation.

Another way to obtain a nanophase of ammonia borane is to blend it with a polymer. Poly(methyl acrylate) is a possible scaffold [280]. The as-obtained nanophase released hydrogen and some ammonia from $70{ }^{\circ} \mathrm{C}$. Comparable behaviors were reported for polyacrylamide and polyvinylpyrrolidone [281, 282]. With hyper-crosslinked porous polymers, ammonia borane is infiltrated by the capillary effect. For instance, Tang et al. [283] used poly(styrene-co-divinylbenzene) with a specific surface area of 757 $\mathrm{m}^{2} \mathrm{~g}^{-1}$ and a pore volume of $0.88 \mathrm{~cm}^{3} \mathrm{~g}^{-1}$. The ammonia borane nanophase was in the form of 4-nm nanoparticles, and released pure hydrogen from $50^{\circ} \mathrm{C}$. A last synthetic approach is nanostructuration by electrospinning, where nanofibers of a polymer encapsulating ammonia borane are elaborated. Useful polymers for that purpose are polystyrene [284], polyvinylpyrrolidone [285], poly(methyl methacrylate) [286], polyethylene oxide [287] and polyacrylamide [288]. In each case, embedded ammonia borane nanophase showed improved dehydrogenation properties in comparison with the bulk counterpart, but the release of some ammonia, diborane and/or borazine could not be avoided. The first, obvious, effect explaining the better dehydrogenation properties is nanosizing (Figure 15). The other effect is related to the occurrence of $\mathrm{C}=\mathrm{O} \cdots \mathrm{BH}_{3}$ interactions between the polymer and the 
ammonia borane. These interactions weaken the $\mathrm{B}-\mathrm{H}, \mathrm{N}-\mathrm{H}$ and $\mathrm{B}-\mathrm{N}$ bonds of ammonia borane, thereby favoring the release of hydrogen but also driving the release of ammonia because of weakened B-N bonds $[289,290]$.

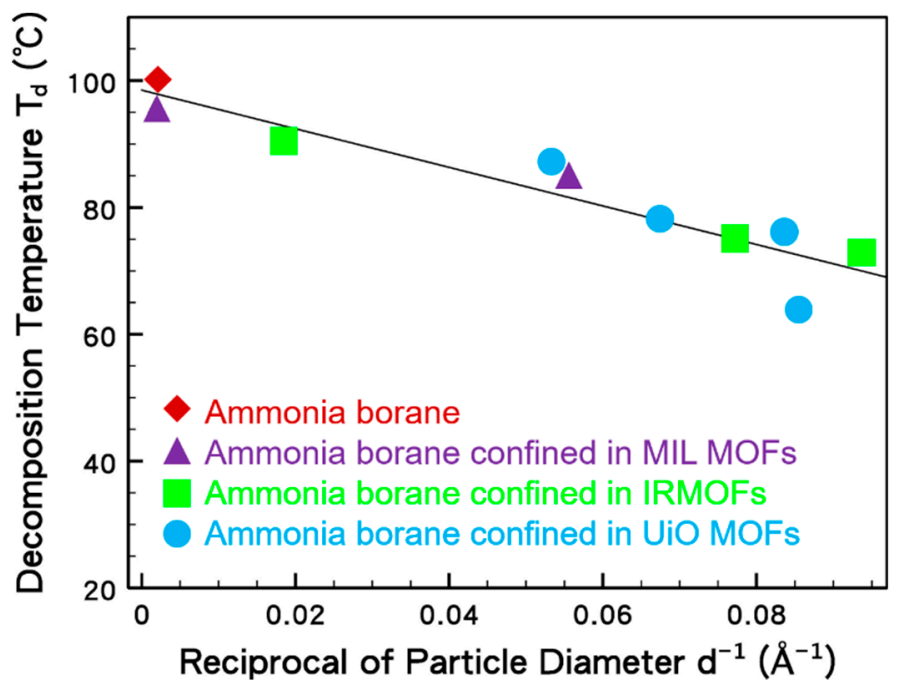

Figure 16. Peaked temperature of decomposition $\left(\mathrm{T}_{\mathrm{d}}\right)$ of ammonia borane in a pristine state, confined in MIL MOFs, IRMOFs and UiO MOFs, as a function of the reciprocal particle size of ammonia borane particle sizes. Reprinted with permission from ref. [274]. Copyright 2017 American Chemical Society.

There are few other examples of scaffolds. Boron nitride, in the form of porous hollow nanopolyhedra (a mean diameter of $70 \mathrm{~nm}$, wall thickness of $5 \mathrm{~nm}$ and total pore volume of $0.424 \mathrm{~cm}^{3} \mathrm{~g}^{-1}$ ), was found to effectively nanosize and destabilize ammonia borane from $40{ }^{\circ} \mathrm{C}$ [291]. The destabilization was due to a pure nanoconfinement effect, because the surface of the boron nitride scaffold was totally hydrogen-free. The release of some $\mathrm{NH}_{3}$ was, however, detected. Another example is manganese oxide. With porous hollow cubes (diameter of $400 \mathrm{~nm}$, wall thickness of $40 \mathrm{~nm}$ and porous volume of $1.05 \mathrm{~cm}^{3} \mathrm{~g}^{-1}$ ) [292] and porous hollow spheres (diameter of 1-2 $\mu \mathrm{m} \mathrm{nm}$, wall thickness of $80 \mathrm{~nm}$ and porous volume of $0.47 \mathrm{~cm}^{3} \mathrm{~g}^{-1}$ ) [293], the ammonia borane nanophase released pure hydrogen from $60^{\circ} \mathrm{C}$ due to the nanosizing effect.

The nanosizing effect has clearly shown to be successful. Pure hydrogen can be generated at very low temperatures, though the presence of gaseous by-products is still possible. However, overly low temperatures, like the ambient temperature, should be avoided for safety and technical reasons. Given the variety of the scaffolds reported so far, there is room for finding the optimal conditions for the release of pure hydrogen. In fact, the nanoconfinement strategy faces two salient issues. Ironically, the first issue is the scaffold. It has a weight and, because of it, there is a mass penalty, resulting in a substantial drop of the theoretical gravimetric hydrogen storage capacity of the pair scaffold-ammonia borane (Figure 17). The second issue is related to the formation of highly stable $\mathrm{B}-\mathrm{O}$ bonds upon the dehydrogenation of ammonia borane infiltrated into most of the scaffolds reported above. This is an added complication for the tricky recycling of the polymeric residue (cf. Section 5.6). Here, also, the lack of effort towards scaling up is to be regretted. 


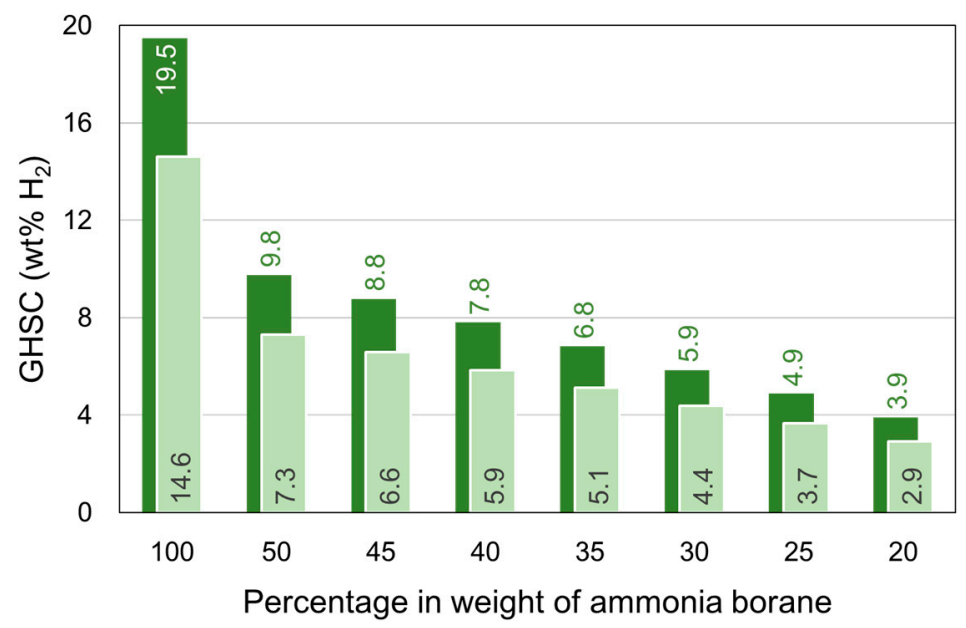

Figure 17. Gravimetric hydrogen storage capacity (GHSC) of ammonia borane (20 to $50 \%$ in weight) confined into a scaffold ( 80 to $50 \%$ in weight). For comparison, pure ammonia borane ( $100 \%$ in weight) is also shown. With respect to the bars with no border, the capacity is based on $100 \%$ on the hydrogens of ammonia borane. For the bars with the white borders, it is assumed that $75 \%$ of the hydrogen of ammonia borane can be released. The capacities (in $\mathrm{w} t \% \mathrm{H}_{2}$ ) are all given.

\subsection{Alkali and Alkaline-Earth Derivatives of Ammonia Borane}

The last, but not the least, of the destabilization strategies is to make ammonia borane evolve towards a derivative. In a simple way, one of the protic hydrogens $\mathrm{H}^{\delta+}$ of ammonia borane is substituted by a cation, like an alkali metal, leading to a new compound; an amidoborane. The first amidoborane, sodium amidoborane $\mathrm{NaNH}_{2} \mathrm{BH}_{3}$, was discovered in the 1930s by Schlesinger et al. [29,31]. A few others were discovered in the 1990s. Shore and co-workers studied some amidoboranes, including sodium, lithium and potassium salts [294-296]. Myers et al. [297] synthesized the lithium counterpart, $\mathrm{LiNH}_{2} \mathrm{BH}_{3}$. In recent history, relating to ammonia borane, the first derivative to emerge was an alkaline earth compound, namely calcium amidoborane $\mathrm{Ca}\left(\mathrm{NH}_{2} \mathrm{BH}_{3}\right)_{2}$ [298]. Since then, a number of amidoboranes have been discovered. It goes beyond the scope of the present work to survey all of the mono- and multi-metallic amidoboranes reported so far. All have been discussed at length in a series of reviews [299-303], and hereafter only the monometallic alkali and alkaline-earth amidoboranes are tackled.

Lithium amidoborane $\mathrm{LiNH}_{2} \mathrm{BH}_{3}$ is easily prepared by, for example, ball-milling an equimolar mixture of ammonia borane and lithium hydride $\mathrm{LiH}$ [304]:

$$
\mathrm{H}_{3} \mathrm{~N}-\mathrm{BH}_{3}+\mathrm{LiH} \rightarrow \mathrm{LiNH}_{2} \mathrm{BH}_{3}+\mathrm{H}_{2}
$$

It is worth briefly mentioning that there are alternative routes for preparing alkali amidoboranes, as surveyed in details in refs. [299-303]. Lithium amidoborane is a crystalline solid, having two allotropes, the $\alpha$ and the $\beta$ phases; both crystallize in the orthorhombic space group Pbca, but the unit cell of the $\beta$ phase is twice that of the $\alpha$ phase [305]. Lithium amidoborane has a high gravimetric hydrogen density, with $13.7 \mathrm{wt} \% \mathrm{H}_{2}$, and this makes it attractive in the field. Under heating, it dehydrogenates according to a nearly thermally neutral event $\left(-3 \mathrm{~kJ} \mathrm{~mol}^{-1}\right)$, and at temperatures below $100{ }^{\circ} \mathrm{C}$ [306]. The purity of the released hydrogen is not clear. It was claimed to be either pure [307] or polluted with some ammonia [308]. With sodium amidoborane $\mathrm{NaNH}_{2} \mathrm{BH}_{3}$ (orthorhombic, with a $\mathrm{Pbca}$ space group), the high weight of sodium results in a lower gravimetric hydrogen density, with $9.6 \mathrm{wt} \% \mathrm{H}_{2}$. It can be prepared by gentle ball-milling [309], or even by a simple mixing in an inert atmosphere [310], because sodium hydride is more reactive than lithium hydride [311]. Under heating, at $80^{\circ} \mathrm{C}$, it was found to release 0.5 equivalents of hydrogen in about $1.5 \mathrm{~min}$, whereas a time of about $50 \mathrm{~min}$ was required for the lithium compound [307]. Traces of ammonia were, however, detected [312]. 
The synthesis of potassium amidoborane requires safer vessel (a stainless steel autoclave), and a solvent like tetrahydrofuran, because potassium hydride, a base stronger than the aforementioned metal hydrides, reacts violently with ammonia borane [313]. Potassium amidoborane crystallizes in the orthorhombic space group Pbca. It carries $7.3 \mathrm{wt} \%$ of hydrogen. It is less stable than the parent ammonia borane, releasing 1.5 equivalents of pure hydrogen up to $100^{\circ} \mathrm{C}$. Note that it cannot be compared to the previous alkali amidoboranes because of discrepancies in the conditions of the dehydrogenation experiments. Though less attractive in terms of gravimetric hydrogen density, rubidium amidoborane $\mathrm{RbNH}_{2} \mathrm{BH}_{3}\left(4.4 \mathrm{wt} \% \mathrm{H}_{2}\right.$ ) and cesium amidoborane $\mathrm{CsNH}_{2} \mathrm{BH}_{3}\left(3.1 \mathrm{wt} \% \mathrm{H}_{2}\right.$ ) were synthesized by reacting the metal with ammonia borane in anhydrous tetrahydrofuran; for example [314]:

$$
\mathrm{H}_{3} \mathrm{~N}-\mathrm{BH}_{3}+\mathrm{Rb} \rightarrow \mathrm{RbNH}_{2} \mathrm{BH}_{3}+1 / 2 \mathrm{H}_{2}
$$

Both are crystalline [315]. The former crystallizes in a monoclinic system, with the space group $P 2_{1} / c$. The latter crystallizes in a primitive orthorhombic structure and the space group Pnam. They decompose over the temperature range of $55-100{ }^{\circ} \mathrm{C}$ while liberating hydrogen and ammonia. In sum, the most attractive amidoboranes for solid-state hydrogen storage are the lithium and sodium compounds (Figure 18); they carry more hydrogen and are able to release quite pure hydrogen below $100{ }^{\circ} \mathrm{C}$ [302].

(a)

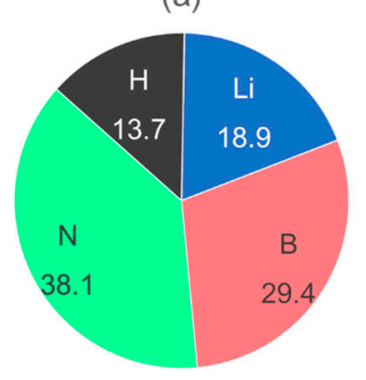

(d)

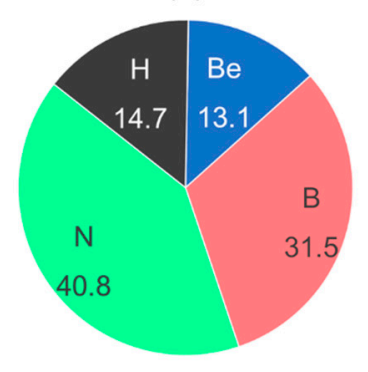

(b)

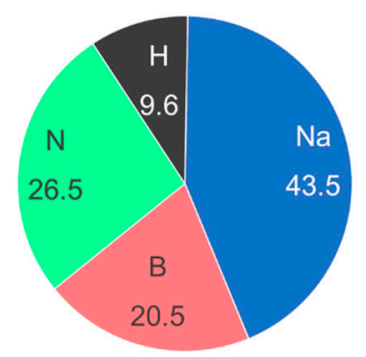

(e)

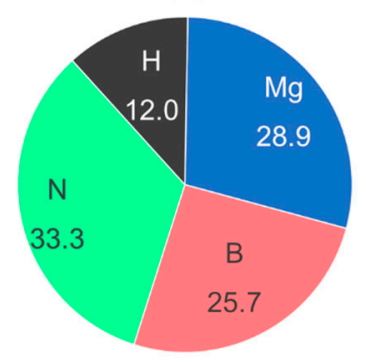

(c)

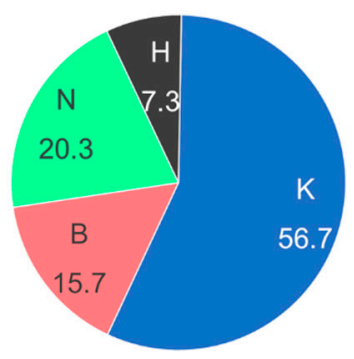

(f)

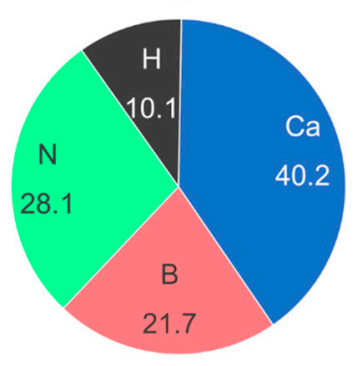

Figure 18. Weight percentage of hydrogen, boron, nitrogen and alkali or alkaline-earth atoms for the amidoboranes of (a) lithium, (b) sodium, (c) potassium, (d) beryllium, (e) magnesium and (f) calcium. The weight percentage of hydrogen is the gravimetric hydrogen density or gravimetric hydrogen storage capacity (in $\mathrm{wt} \% \mathrm{H}_{2}$ ) of the amidoborane.

The better dehydrogenation properties of the alkali amidoboranes (versus ammonia borane) can be explained in two ways. First, the compound becomes ionic, and substantial changes occur in chemical bonding by substituting one protic hydrogen $\mathrm{H}^{\delta+}$ with a metal cation $\mathrm{M}^{+}$[316]: the $\mathrm{M}-\mathrm{N}$ bond is longer than the $\mathrm{H}-\mathrm{N}$ bond in ammonia borane, and the $\mathrm{B}-\mathrm{N}$ bond is slightly shorter, with, for example, $1.53 \AA$ for sodium amidoborane and $1.6 \AA$ for ammonia borane. This has implications (Figure 19). The $\mathrm{B}-\mathrm{N}$ bond is then stronger, the $\mathrm{NH}_{2}$ group is stronger in terms of Lewis basicity and the hydridic hydrogen $\mathrm{H}^{\delta-}$, becoming more basic, is more reactive than its counterpart in ammonia borane [317]. Second, the intermolecular dihydrogen $\mathrm{N}-\mathrm{H}^{\delta+} \ldots \mathrm{H}^{\delta-}-\mathrm{B}$ interactions are weakened with the presence 
of the metal cation [313]; that is, the $\mathrm{H}^{\delta+} \ldots \mathrm{H}^{\delta-}$ distances are longer. A distance of $2.25 \AA$ was suggested for lithium amidoborane, for example [317]. This is longer than the distance $2.02 \AA$ in ammonia borane, but still shorter than the sum of the van der Waals radii for two $\mathrm{H}$ atoms $(2.4 \AA)$. This is an evidence of weaker dihydrogen $\mathrm{N}-\mathrm{H}^{\delta+} \ldots \mathrm{H}^{\delta-}-\mathrm{B}$ interactions [314]. The consequence of these two effects is a lower stability of the amidoboranes in comparison with ammonia borane.
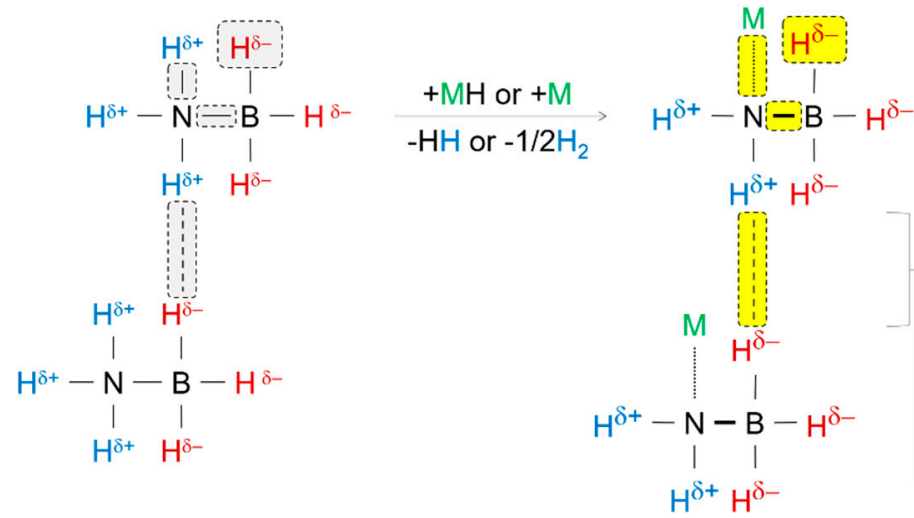

(i) $\mathrm{N}-\mathrm{M}$ bond $>\mathrm{N}-\mathrm{H}$ bond

(ii) More Lewis basic $\mathrm{NH}_{2}$ group

(iii) Shorter and stronger $\mathrm{B}-\mathrm{N}$

(iv) More basic and reactive $\mathrm{H}^{\delta-}$

(i) $\mathrm{N}-\mathrm{M}$ bond $>\mathrm{N}-\mathrm{H}$ bond

(ii) Longer $\mathrm{H}^{\delta+} \ldots \mathrm{H}^{\delta-}$ bonds

Figure 19. Better dehydrogenation properties in amidoboranes (versus ammonia borane) owing to changes in chemical bonding, both intramolecular (e.g., B-N bond) and intermolecular (i.e., dihydrogen $\mathrm{N}-\mathrm{H}^{\delta+} \ldots \mathrm{H}^{\delta-}-\mathrm{B}$ bonds).

With alkaline earth metal cations, the positive charge +2 is counterbalanced by two anions $\left[\mathrm{NH}_{2} \mathrm{BH}_{3}\right]^{-}$. Because of the acute toxicity of beryllium, beryllium amidoborane $\mathrm{Be}\left(\mathrm{NH}_{2} \mathrm{BH}_{3}\right)_{2}$ was investigated virtually, by computational calculations [318]. This is unfortunate, as beryllium amidoborane would have a theoretical gravimetric hydrogen density of $14.7 \mathrm{wt} \% \mathrm{H}_{2}$. The synthesis of magnesium amidoborane $\mathrm{Mg}\left(\mathrm{NH}_{2} \mathrm{BH}_{3}\right)_{2}$ was awkward. Both magnesium hydride and magnesium, as reactants, seemed to be inert towards ammonia borane, which was explained for the former reactant by a weaker Lewis basicity [319]. Luo et al. [320] found the solution to such inertness. To obtain magnesium amidoborane $\left(12 \mathrm{wt} \% \mathrm{H}_{2}\right)$, the mixture of magnesium hydride (or magnesium) and ammonia borane was aged under an argon atmosphere:

$$
2 \mathrm{H}_{3} \mathrm{~N}-\mathrm{BH}_{3}+\mathrm{MgH}_{2} \rightarrow \mathrm{Mg}\left(\mathrm{NH}_{2} \mathrm{BH}_{3}\right)+2 \mathrm{H}_{2}
$$

The reaction required 45 days with magnesium hydride (6 months with magnesium) at ambient temperature. The as-obtained amidoborane (monoclinic, space group C2) is not more attractive than ammonia borane for solid-state hydrogen storage. It dehydrogenates between 100 and $300{ }^{\circ} \mathrm{C}$, through a complex multistep process, resulting in the release of 4.2 equivalents of hydrogen, the formation of polyborazylene-like residues and the presence of a small amount of magnesium hydride. The calcium derivative, $\mathrm{Ca}\left(\mathrm{NH}_{2} \mathrm{BH}_{3}\right)_{2}$, which requires an intense milling to form and isolate a pure phase, is quite challenging. The reactants, calcium hydride $\mathrm{CaH}_{2}$ and ammonia borane, are still present as minor phases [321]. Calcium amidoborane crystallizes in a monoclinic $\mathrm{C} 2$ unit cell, and the $\mathrm{B}-\mathrm{N}$ bond $(1.546 \AA)$ is shorter than that of ammonia borane, suggesting more Lewis basic hydridic hydrogens $\mathrm{H}^{\delta-}$. Calcium amidoborane $\left(10.1 \mathrm{wt} \% \mathrm{H}_{2}\right)$ is less stable, as it releases hydrogen from $80^{\circ} \mathrm{C}$. About four equivalents of hydrogen are formed over the temperature range $80-250^{\circ} \mathrm{C}$. Strontium amidoborane $\mathrm{Sr}\left(\mathrm{NH}_{2} \mathrm{BH}_{3}\right)_{2}\left(6.9 \mathrm{wt} \% \mathrm{H}_{2}\right)$ was reported to form by making pre-milled strontium hydride $\mathrm{SrH}_{2}$ and two equivalents of pre-milled ammonia borane react, the process being performed at $45^{\circ} \mathrm{C}$ for $2 \mathrm{~h}$ [322]. The final product contained $55 \mathrm{wt} \%$ of crystalline strontium amidoborane (isostructural to calcium amidoborane), $34 \mathrm{wt} \%$ of an unidentified phase, $7 \mathrm{wt} \%$ of strontium hydride and $4 \mathrm{wt} \%$ of ammonia borane. As the last representative, amorphous barium amidoborane $\mathrm{Ba}\left(\mathrm{NH}_{2} \mathrm{BH}_{3}\right)$ was obtained by the reaction of metallic barium with ammonia borane in tetrahydrofuran at $-10{ }^{\circ} \mathrm{C}$ [323]. 
Its dehydrogenation properties are comparable to those of calcium amidoborane. It was found to release hydrogen ( $5 \mathrm{wt} \%$ out of a theoretical capacity of $5.1 \mathrm{wt} \%$ ) from 81 to $163{ }^{\circ} \mathrm{C}$. To sum up, alkaline earth amidoboranes are less attractive than their alkali counterparts because they are more difficult to synthesize, they have lower gravimetric hydrogen densities (Figure 18) and they are more thermally stable.

If this destabilization strategy is compared to the ones discussed above, it is the simplest; there is no solvent, no catalyst, no chemical dopant and no scaffold. The amidoborane only needs to be heated up so that it dehydrogenates below $100^{\circ} \mathrm{C}$. Against this background, one can only regret that there has been no scaling up. Data collected in more realistic conditions, from a technological point of view, would have allowed a more technical discussion.

\subsection{The Critical Issue of Regeneration}

In comparison with the efforts made to dehydrogenate ammonia borane, there has been very little effort made to hydrogenate the polymeric residues, those recovered upon thermolytic dehydrogenation [186,324].

Hausdorf et al. [325] used a polymeric residue denoted $\mathrm{BNH}_{<2}$, which was prepared from ammonia borane heated at $90^{\circ} \mathrm{C}$ for $12 \mathrm{~h}$ and then $180^{\circ} \mathrm{C}$ for $2 \mathrm{~h}$. The polymeric residue was first digested in hydrochloric acid (Figure 20), the product ammonium chloride $\mathrm{NH}_{4} \mathrm{Cl}$ was recovered to produce ammonia, the product boron trichloride $\mathrm{BCl}_{3}$ was hydrodechlorinated to form diborane $\mathrm{B}_{2} \mathrm{H}_{6}$ and finally the as-obtained ammonia and diborane were reacted to form ammonia borane. Instead of hydrochloric acid, the superacid systems $\mathrm{AlBr}_{3} / \mathrm{HBr} / \mathrm{CS}_{2}$ and $\mathrm{AlCl}_{3} / \mathrm{HCl} /$ toluene were also used, with the regeneration leading to ammonia borane, with a yield of $60 \%$ [326]. An alternative path was suggested by Davis et al. [327]. Using polyborazylene as a model polymeric residue, a digestion-reduction path using a thiol and a tin hydride was suggested. The $\mathrm{B}-\mathrm{N}$ bonds of the polymeric residue were broken by the action of the thiol, and the as-formed intermediates were reduced in the presence of an excess tin hydride, allowing the formation of ammonia borane with a yield of $67 \%$. These two regeneration schemes were later combined by Tan et al. [328]. They proposed a derived method based on the use of the superacid system $\mathrm{AlCl}_{3} / \mathrm{HCl} / \mathrm{CS}_{2}$ for the digestion step and a tin hydride for the reduction step. An improved yield of $89 \%$ was calculated.

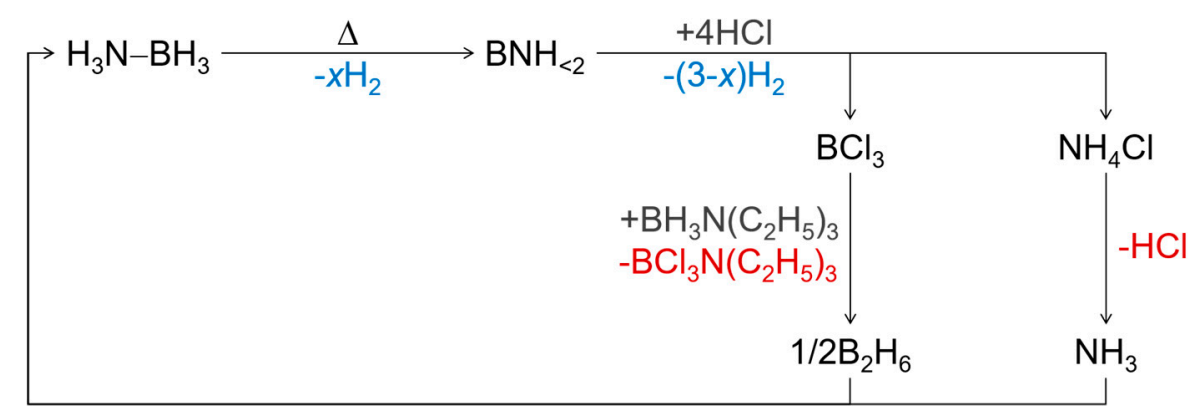

Figure 20. Regeneration of ammonia borane by acidic digestion of the solid residue $\mathrm{BNH}_{<2}$, followed by hydrodechlorination of boron trichloride and decomposition of ammonium chloride into ammonia, and finally a Lewis acid-base reaction between diborane and ammonia. Adapted from ref. [325].

Another regeneration strategy was proposed by Sutton et al. [329]. Polyborazylene was used as model polymeric residue and, through a one-pot process (Figure 21), ammonia borane was regenerated with a yield higher than $90 \%$. This is a simple process, where the polymer is suspended in liquid ammonia at $-77^{\circ} \mathrm{C}$ and then reduced by hydrazine at $40{ }^{\circ} \mathrm{C}$ for $24 \mathrm{~h}$. According to Hua and Ahluwalia [330], who analyzed these processes in terms of energy consumption, efficiency and life cycle greenhouse gas emissions, none are energy efficient. 


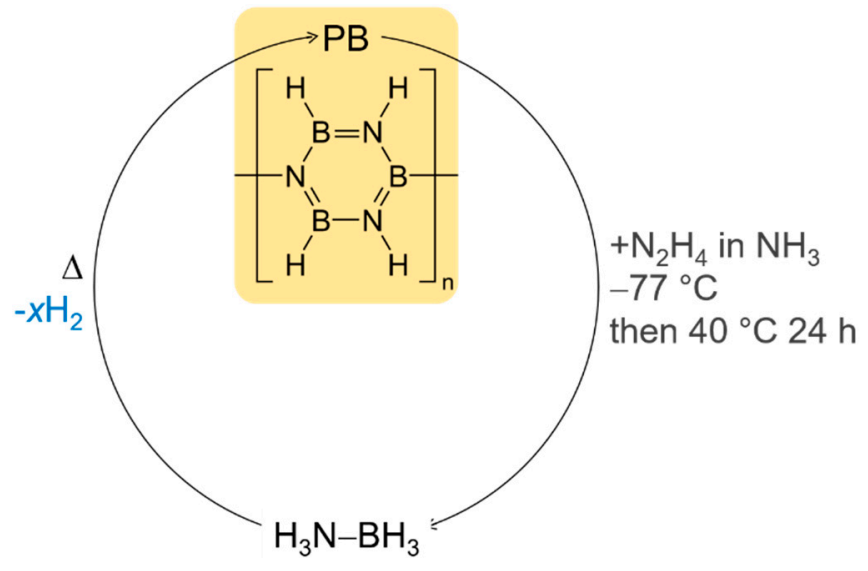

Figure 21. Regeneration of ammonia borane by reduction of polyborazylene (PB) by hydrazine in ammonia. Adapted from ref. [329].

As for ammonia borane, the dehydrogenation of the amidoboranes is exothermic, and direct rehydrogenation is thermodynamically impossible at affordable conditions. Attempts up to 120 bars of hydrogen and $30{ }^{\circ} \mathrm{C}$ were found to be ineffective [309,317,319]. The only feasible approach is chemical reduction, as discussed above. Tang et al. [331] successfully applied the process using hydrazine as a reducing agent and ammonia as a solvent (Figure 21) to a polymeric residue recovered upon the dehydrogenation of lithium amidoborane. The starting ammonia borane was regenerated with a yield of $63 \%$. This approach, like the ones discussed above, cannot be applied for the reduction of $\mathrm{B}-\mathrm{O}$ bonds into $\mathrm{B}-\mathrm{H}$ bonds.

It is worth mentioning another approach that could be considered for any polymeric residue, whether they contain $\mathrm{B}-\mathrm{O}$ bonds or not. Tang et al. [332] suggested a digestion of the polymeric residue into methanol, resulting in the methanolysis of the polymeric residue and formation of trimethoxyborate $\mathrm{B}\left(\mathrm{OCH}_{3}\right)_{3}$. Then, the authors applied the ammonia borane one-pot synthesis procedure developed by Ramachandran et al. [168]. The trimethoxyborate was reduced by lithium alanate in the presence of ammonium chloride acting as ammonia source (Equation (18) and Figure 7). The as-obtained ammonia borane can then be reacted with lithium hydride to form lithium amidoborane, for example (Equation (28)). The energy efficiency of this process was calculated to be about $46 \%$, and the authors concluded that the process is not effective enough.

\section{Conclusions and Outlook}

The main feature of ammonia borane is that it is versatile. Owing to the hydridic hydrogens $\mathrm{H}^{\delta-}$ it is made of, it can be used as an anodic fuel, a hydrolytic hydrogen carrier and a solid-state hydrogen storage material. Re-emerging in the mid-2000s, it demonstrated its potential for each of these applications, raising wide interest, as well as questions. The title of an article authored by Marder in 2007 is explicit. The author wondered whether we will soon be fueling automobiles with ammonia borane [333]. At that time, ammonia borane seemed to be full of promise-the automobile application, which is the most challenging, was targeted-but it was as if ammonia borane offered no guarantee. After 15 years of research, we may be pessimistic on the technological future of ammonia borane. The fact is, ammonia borane has barely been scaled up, which is a failure in terms of technological implementation.

The reality is that preventable errors have been made with ammonia borane. One of them has been mentioned just above. The technological readiness level of ammonia borane has remained low (Figure 22), mainly at the laboratory and milligram scales. There should have been more actions and efforts towards scaling up, i.e., towards the construction and operation of demonstrators and prototypes. This would have helped researchers gain more insight into the problems facing its applications as an anodic fuel and hydrogen carrier. It is obvious that the technological future of ammonia borane, 
if any, will be promoted through scaling up. The ammonia borane nanophase, on the one hand, and lithium or sodium amidoborane, on the other, are mature enough to be investigated at the scale of a few dozen grams. Inspiration in this regard should be taken from the demonstrator based on 58 $\mathrm{g}$ of glycol-doped ammonia borane providing enough hydrogen to power a 200-We fuel cell [237]. Inspiration should be also taken from the few prototypes and devices using sodium borohydride as a hydrolytic hydrogen carrier [21]. It is likely that scaling up of ammonia borane went beyond the aforementioned demonstrator. Unfortunately, there has been very little communication. For instance, the company Cella Energy Ltd. (insolvent in 2018-2019 [334] and now bankrupt) developed plastic pellets consisting of ammonia borane enclosed in a polymeric shell [284], and briefly communicated about a successful unmanned aerial vehicle test flight [335], the vehicle being powered by a power system based on the ammonia borane-based pellets.

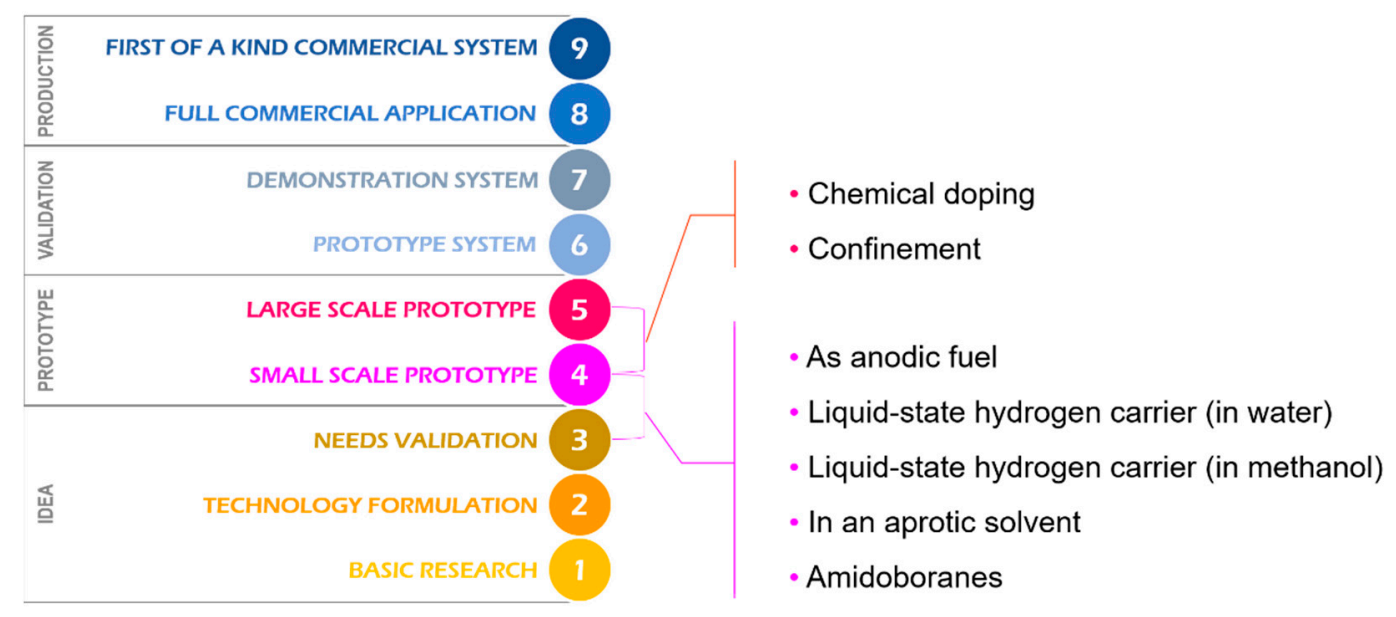

Figure 22. Estimation of the technological readiness level of ammonia borane as an anodic fuel, a liquid-state hydrogen carrier and a solid hydrogen carrier. The prototypes reported in ref. [237] and in ref. [335] have been taken into account to take the chemical doping and confinement strategies to a higher level than the other approaches.

Another preventable error has been to underestimate critical issues. The example of ammonia borane hydrolysis is characteristic and indicative. This reaction (Equations (6) and (7)) can be divided into five aspects (the optimization of the couple ammonia borane-water, catalyst and catalysis, purity of hydrogen due to the release of ammonia, nature of the borates and regeneration of ammonia borane) that are equally important. However, one of them (catalyst and catalysis) has been disproportionately scrutinized, and the others have regrettably been understudied. Consequently, it is difficult at present to argue the hydrolysis abilities in terms of effective gravimetric hydrogen storage capacities, purity of the released hydrogen, number and nature of the by-products and regeneration of ammonia borane. The same error, viz. underestimating critical issues, can be observed in the electro-oxidation, methanolysis and thermolysis of ammonia borane. An example for each reaction is as follows. In electro-oxidation, the impact of ammonia on, for example, the electrocatalyst and the membrane has not been investigated thoroughly. In methanolysis, it is not clear whether there is one borate forming upon reaction or if there are several in equilibrium. In thermolysis, the effective gravimetric hydrogen storage capacities have not been optimized and properly determined yet. Those all affect the technological maturity of ammonia borane.

We may well have overestimated the potential of ammonia borane. For instance, a mere 15 years ago, we were wondering whether ammonia borane would be a fuel for automobiles [333]. Today, it is obvious that ammonia borane is far from having demonstrated such potential. Three concrete examples illustrate the error that has been made. First, the gravimetric hydrogen density $19.5 \mathrm{wt} \% \mathrm{H}_{2}$ of ammonia borane was put forward. This value is far from the net, i.e., real and useable, gravimetric 
hydrogen storage capacities; in such a case, the storage system as a whole is taken into account; that is, the system weight (accounting for $50 \mathrm{wt} \%$ in a first approximation) is considered for the calculations of the net capacities (Figure 23). The weight of the system is then seen as a 'dead mass', negatively impacting the storage capacities. For instance, in the hydrolysis of ammonia borane, the highest net capacity would be $3.5 \mathrm{wt} \% \mathrm{H}_{2}$. For ammonia borane doped with $20 \mathrm{wt} \%$ of a chemical additive, the net capacity could be $5.9 \mathrm{wt} \% \mathrm{H}_{2}$. In the thermolysis of nanoconfined ammonia borane, the highest net capacity would be $3.7 \mathrm{wt} \% \mathrm{H}_{2}$. With lithium amidoborane dehydrogenating at an extent of $75 \%$, the net capacity would reach $5.2 \mathrm{wt} \% \mathrm{H}_{2}$. It is worth mentioning that an ultimate net capacity of $6.5 \mathrm{wt} \% \mathrm{H}_{2}$ is expected for light-duty vehicles [336]. Second, it is not clear whether the hydrogen release kinetics (in terms of rate and/or variability) are suitable for automotive applications. This question is also relevant for other applications (mobile, portable and stationary). There are some answers in hydrolysis and very few in electro-oxidation and thermolysis. Third, ammonia borane was, unintentionally and/or unmindfully, addressed as gasoline. Consider the analogy. A lot of the efforts have focused on improving and optimizing the conversion of both fuels, whereas very little consideration was given to the by-products (borates and polymeric residues, versus carbon dioxide). The analogy breaks down at this point. Ammonia borane cannot be compared with gasoline. The chemistry behind it, the issues and the challenges ahead and the absolute necessity to close the hydrogen cycle, among others, make ammonia borane radically and conceptually different from gasoline. It is hoped that ammonia borane will, in the near-future, contribute to powering electrical devices. It is unlikely, however, that it supersedes gasoline.

(a)

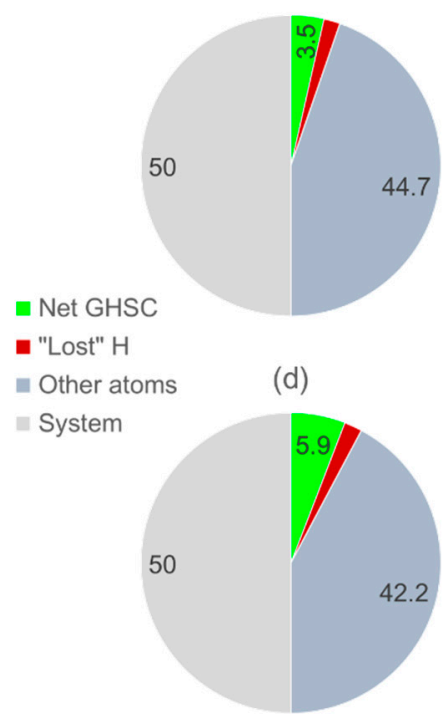

(b)

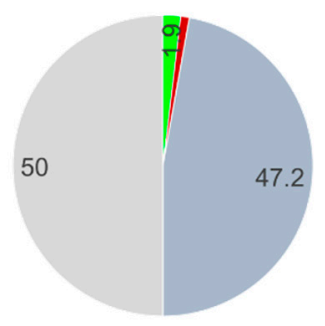

(e)

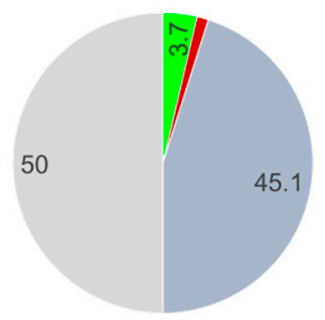

(c)

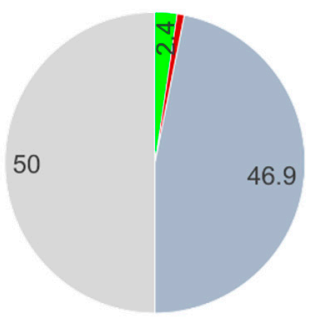

(f)

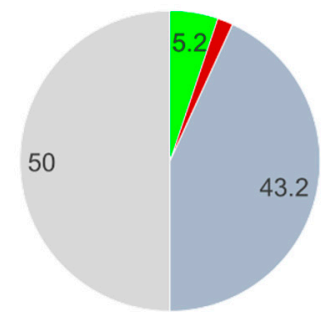

Figure 23. Net (i.e., useable) gravimetric hydrogen storage capacity (GHSC, in $\mathrm{wt}^{\mathrm{o}} \mathrm{\textrm {H } _ { 2 }}$ ) for a storage system taken as a whole, in the case of (a) ammonia borane as liquid-state hydrogen carrier in water (in stoichiometric conditions such as in Equation (6)), (b) ammonia borane as liquid-state hydrogen carrier in methanol (in stoichiometric conditions such as in Equation (17)), (c) ammonia borane in saturation in the $\mathrm{BmimCl}$ ionic liquid (assuming the release of $75 \%$ of the borane's hydrogen), (d) $80 \mathrm{wt} \%$ of ammonia borane doped with $20 \mathrm{wt} \%$ of a chemical additive (assuming the release of $75 \%$ of ammonia borane's hydrogen), (e) ammonia borane confined into a scaffold (50-50 wt \%; assuming the release of $75 \%$ of the ammonia borane's hydrogen) and (f) lithium amidoborane as derivative of ammonia borane (assuming the release of $75 \%$ of the amidoborane's hydrogen). The weight percentages of the lost hydrogen atoms, of the other atoms (e.g., B, N, C and O) and of the storage system (set at $50 \mathrm{wt} \%$ of the total weight) are shown. 
As a final point, the competition is high. Ammonia borane has, in front of it, promising and cheaper hydrides. The cost issue has not been tackled above, appearing inappropriate because of discrepancies in many aspects, but it can be briefly discussed for comparing one material with another. For instance, ammonia borane is commonly synthesized from sodium borohydride. It is thus more costly. As long as ammonia borane is not regenerated from its own by-products, it will remain more costly than sodium borohydride, for which regeneration paths exist. It is therefore obvious that, for the same level of performance, the sodium borohydride-based technology will be cheaper. The problem is that ammonia borane performs less well than sodium borohydride for the electro-oxidation, hydrolysis and methanolysis reactions. For example, the specific energy and pure compound capacity of sodium borohydride are higher. The hydrogen released by hydrolysis and methanolysis of sodium borohydride is purer, and free of ammonia. With respect to ammonia borane as a solid-state hydrogen carrier, the situation is different. It is certainly the best material in many aspects, such as the temperature of dehydrogenation and the amount of hydrogen that can be released. However, there is one aspect that is detrimental to ammonia borane. The dehydrogenation is exothermic, and thus the storage of hydrogen is irreversible. In other words, the polymeric residue stemming from ammonia borane cannot be hydrogenated under the pressure of hydrogen, which is a limitation. Accordingly, the question may legitimately be asked whether the main critical impediment to ammonia borane development is not the fact that it stores hydrogen irreversibly.

Ammonia borane has failed to play an important role in the deploying hydrogen economy. More optimistically, it has lagged behind. The absolute requirement to regenerate it, from its oxidation, hydrolysis, methanolysis and thermolysis products, has been and remains its Achilles heel. That is where more efforts should be expended, in order to go through significant achievements and breakthroughs. Without an industry dedicated to ammonia borane regeneration, ammonia borane will have no large-scale commercial future. Concomitantly, more efforts should be made in scaling up, in constructing and operating demonstrators and prototypes. The technological readiness level should then rise. Ammonia borane should get outside the laboratory hood and be studied in near-real and real conditions.

Funding: This research received no external funding.

Acknowledgments: This review article, for which I managed more than 300 articles, was written during the home confinement we suffered in spring 2020 (because of the pandemic), and I would like to warmly thank my daughter Asya, my sons Kubilay and Timuçin and my wife Sureyya for their understanding, patience and support.

Conflicts of Interest: The author declares no conflict of interest.

\section{References}

1. Chapman, A.; Itaoka, A.; Farabi-Asl, H.; Fujii, Y.; Nakahara, M. Societal penetration of hydrogen into the future energy system: Impacts of policy; technology and carbon targets. Int. J. Hydrog. Energy 2020, 45, 3883-3898. [CrossRef]

2. Dawood, F.; Anda, M.; Shafiullah, G.M. Hydrogen production for energy: An overview. Int. J. Hydrog. Energy 2020, 45, 3847-3869. [CrossRef]

3. Kurtz, J.; Sprik, S.; Bradley, T.H. Review of transportation hydrogen infrastructure performance and reliability. Int. J. Hydrog. Energy 2019, 44, 12010-12023. [CrossRef]

4. Moradi, R.; Groth, K.M. Hydrogen storage and delivery: Review of the state of the art technologies and risk and reliability analysis. Int. J. Hydrog. Energy 2019, 44, 12254-12269. [CrossRef]

5. Ren, J.; Musyoka, N.M.; Langmi, H.W.; Mathe, M.; Liao, S. Current research trends and perspectives on materials-based hydrogen storage solutions: A critical review. Int. J. Hydrog. Energy 2017, 42, $289-311$. [CrossRef]

6. Dimitriou, P.; Tsujimura, T. A review of hydrogen as a compression ignition engine fuel. Int. J. Hydrog. Energy 2017, 42, 24470-24486. [CrossRef]

7. Alaswad, A.; Baroutaji, A.; Achour, H.; Carton, J.; Al Makky, A.; Olabi, A.G. Developments in fuel cell technologies in the transport sector. Int. J. Hydrog. Energy 2016, 41, 16499-16508. [CrossRef] 
8. Hirscher, M. Hydrogen storage by cryoadsorption in ultrahigh-porosity metal-organic frameworks. Angew. Chem. Int. Ed. 2011, 50, 581-582. [CrossRef]

9. Lai, Q.; Sun, Y.; Wang, T.; Modi, P.; Cazorla, C.; Demirci, U.B.; Ares Fernandez, J.R.; Leardini, F.; Aguey-Zinsou, K.F. How to design hydrogen storage materials? Fundamentals, synthesis, and storage tanks. Adv. Sust. Syst. 2019, 3, 1900043. [CrossRef]

10. Aakko-Saksa, P.T.; Cook, C.; Kiviaho, J.; Repo, T. Liquid organic hydrogen carriers for transportation and storing of renewable energy—Review and discussion. J. Power Sources 2018, 396, 803-823. [CrossRef]

11. Milanese, C.; Garroni, S.; Gennari, F.; Marini, A.; Klassen, T.; Dornheim, M.; Pistidda, C. Solid state hydrogen storage in alanates and alanate-based compounds: A review. Metals 2018, 8, 567. [CrossRef]

12. Kojima, Y. Hydrogen storage materials for hydrogen and energy carriers. Int. J. Hydrog. Energy 2019, 44, 18179-18192. [CrossRef]

13. Lyu, J.; Lider, A.; Kudiiarov, V. Using ball milling for modification of the hydrogenation/dehydrogenation process in magnesium-based hydrogen storage materials: An overview. Metals 2019, 9, 768. [CrossRef]

14. Koohi-Fayegh, S.; Rosen, M.A. A review of energy storage types, applications and recent developments. J. Energy Storage 2020, 27, 101047. [CrossRef]

15. Milanese, C.; Jensen, T.R.; Hauback, B.C.; Pistidda, C.; Dornheim, M.; Yang, Y.; Lombardo, L.; Zuettel, A.; Filinchuk, Y.; Ngene, P.; et al. Complex hydrides for energy storage. Int. J. Hydrog. Energy 2019, 44, 7860-7874. [CrossRef]

16. Kumar, R.; Karkamkar, A.; Bowden, M.; Autrey, M. Solid-state hydrogen rich boron-nitrogen compounds for energy storage. Chem. Soc. Rev. 2019, 48, 5350-5380. [CrossRef] [PubMed]

17. Demirci, U.B. Sodium borohydride for the near-future energy: A "rough diamond" for Turkey. Turk. J. Chem. 2018, 42, 193-220. [CrossRef]

18. Demirci, U.B. Ammonia borane, a material with exceptional properties for chemical hydrogen storage. Int. J. Hydrog. Energy 2017, 42, 9978-10013. [CrossRef]

19. Moury, R.; Demirci, U.B. Hydrazine borane and hydrazinidoboranes as chemical hydrogen storage materials. Energies 2015, 8, 3118-3141. [CrossRef]

20. Demirci, U.B. The hydrogen cycle with the hydrolysis of sodium borohydride: A statistical approach for highlighting the scientific/technical issues to prioritize in the field. Int. J. Hydrog. Energy 2015, 40, 2673-2691. [CrossRef]

21. Demirci, U.B. About the technological readiness of the $\mathrm{H}_{2}$ generation by hydrolysis of $\mathrm{B}(-\mathrm{N})-\mathrm{H}$ compounds. Energy Technol. 2018, 6, 470-486. [CrossRef]

22. Chandra, M.; Xu, Q. A high-performance hydrogen generation system: Transition metal-catalyzed dissociation and hydrolysis of ammonia-borane. J. Power Sources 2006, 156, 190-194. [CrossRef]

23. Gutowska, A.; Liyu, L.; Shin, Y.; Wang, C.M.; Li, X.S.; Linehan, J.C.; Smith, R.S.; Kay, B.D.; Schmid, B.; Shaw, W.; et al. Nanoscaffold mediates hydrogen release and the reactivity of ammonia borane. Angew. Chem. Int. Ed. 2005, 44, 3578-3582. [CrossRef] [PubMed]

24. Hügle, T.; Kühnel, M.F.; Lentz, D. Hydrazine borane: A promising hydrogen storage material. J. Am. Chem. Soc. 2009, 131, 7444-7446. [CrossRef] [PubMed]

25. Karahan, S.; Zahmakıran, M.; Özkar, S. Catalytic hydrolysis of hydrazine borane for chemical hydrogen storage: Highly efficient and fast hydrogen generation system at room temperature. Int. J. Hydrog. Energy 2011, 36, 4958-4966. [CrossRef]

26. Moury, R.; Moussa, G.M.; Demirci, U.B.; Hannauer, J.; Bernard, S.; Petit, E.; van der Lee, A.; Miele, P. Hydrazine borane: Synthesis, characterization, and application prospects in chemical hydrogen storage. Phys. Chem. Chem. Phys. 2012, 14, 1768-1777. [CrossRef]

27. Demirci, U.B. Impact of H.I. Schlesinger's discoveries upon the course of modern chemistry on B-(N-)H hydrogen carriers. Int. J. Hydrog. Energy 2017, 42, 21048-21062. [CrossRef]

28. Burg, A.B.; Schlesinger, H.I. Hydrides of boron. VII. Evidence of the transitory existence of borine $\left(\mathrm{BH}_{3}\right)$; borine carbonyl and borine trimethylamine. J. Am. Chem. Soc. 1937, 59, 780-787. [CrossRef]

29. Schlesinger, H.I.; Burg, A.B. Hydrides of boron. VIII. The structure of diammoniate of diborane and its relation to the structure of diborane. J. Am. Chem. Soc. 1938, 60, 290-299. [CrossRef]

30. Schlesinger, H.I.; Ritter, D.M.; Burg, A.B. Hydrides of boron. X. The preparation and preliminary study of the new compound $\mathrm{B}_{2} \mathrm{H}_{7}$ N. J. Am. Chem. Soc. 1938, 60, 2297-2300. [CrossRef] 
31. Schlesinger, H.I.; Burg, A.B. Recent developments in the chemistry of the boron hydrides. Chem. Rev. 1942, 31, 1-41. [CrossRef]

32. Schaeffer, G.W.; Schaeffer, R.; Schlesinger, H.I. The preparation of borazole and its reaction with boron halides. J. Am. Chem. Soc. 1951, 73, 1612-1614. [CrossRef]

33. Shore, S.G.; Parry, P.W. The crystalline compound ammonia-borane, $\mathrm{H}_{3} \mathrm{NBH}_{3}$. J. Am. Chem. Soc. 1955, 77, 6084-6085. [CrossRef]

34. Shore, S.G.; Parry, P.W. Chemical evidence of the structure of "diammoniate of diborane." II. The preparation of ammonia-borane. J. Am. Chem. Soc. 1958, 80, 8-12. [CrossRef]

35. Shore, S.G.; Bödekker, K.W. Large scale synthesis of $\mathrm{H}_{2} \mathrm{~B}\left(\mathrm{NH}_{3}\right)_{2}{ }^{+} \mathrm{BH}_{4}{ }^{-}$and $\mathrm{H}_{3} \mathrm{NBH}_{3}$. Inorg. Chem. 1964, 3, 914-915. [CrossRef]

36. Hu, M.G.; Van Paasschen, J.M.; Geanangel, R.A. New synthetic approaches to ammonia-borane and its deuterated derivatives. J. Inorg. Nucl. Chem. 1977, 39, 2147-2150. [CrossRef]

37. Ramachandran, P.V.; Gagare, P.D. Preparation of ammonia borane in high yield and purity, methanolysis and regeneration. Inorg. Chem. 2007, 46, 7810-7817. [CrossRef]

38. Heldebrant, D.J.; Karkamkar, A.; Linehan, J.C.; Autrey, T. Synthesis of ammonia borane for hydrogen storage applications. Energy Environ. Sci. 2008, 1, 156-160. [CrossRef]

39. Figen, A.A.; Pişkin, M.B.; Coşkuner, B.; Imamoğlu, V. Synthesis, structural characterization, and hydrolysis of ammonia borane $\left(\mathrm{NH}_{3} \mathrm{BH}_{3}\right)$ as a hydrogen carrier. Int. J. Hydrog. Energy 2013, 38, 16215-16228. [CrossRef]

40. Ramachandran, P.V.; Kulkarni, A.S. The role of ammonia in promoting ammonia borane synthesis. Dalton Trans. 2016, 45, 16433-16440. [CrossRef]

41. Ramachandran, P.V.; Kulkarni, A.S. Water-promoted, safe and scalable preparation of ammonia borane. Int. J. Hydrog. Energy 2016, 42, 1451-1455. [CrossRef]

42. Petit, J.F.; Miele, P.; Demirci, U.B. Ammonia borane $\mathrm{H}_{3} \mathrm{~N}-\mathrm{BH}_{3}$ for solid-state chemical hydrogen storage: Different samples with different thermal behaviors. Int. J. Hydrog. Energy 2016, 41, 15462-15470. [CrossRef]

43. Peyerimhoff, S.D. Further study of umbrella vs bridged geometries, SCF-MO and CI calculations for $\mathrm{C}_{2} \mathrm{H}_{6}{ }^{++}$ and ammonia borane. J. Chem. Phys. 1968, 49, 312-325. [CrossRef]

44. Allendorf, M.D.; Melius, C.F. Thermochemistry of molecules in the B-N-Cl-H system: Ab initio predictions using the BAC-MP4 method. J. Phys. Chem. A 1997, 101, 2670-2680. [CrossRef]

45. Palke, W.E. Calculation of the internal rotation barrier and its derivative in $\mathrm{BH}_{3} \mathrm{NH}_{3}$. J. Chem. Phys. 1972, 56, 5308-5312. [CrossRef]

46. Hoffmann, R. Extended Hückel theory. III. Compounds of boron and nitrogen. J. Chem. Phys. 1964, 40, 2474-2480. [CrossRef]

47. Dill, J.D.; Schleyer, P.R.; Pople, J.A. Molecular orbital theory of the electronic structure of organic compounds. XXIV. Geometries and energies of small boron compounds. Comparisons with carbocations. J. Am. Chem. Soc. 1975, 97, 3402-3409. [CrossRef]

48. Staubitz, A.; Robertson, A.P.M.; Manners, I. Ammonia-borane and related compounds as dihydrogen sources. Chem. Rev. 2010, 110, 4079-4124. [CrossRef]

49. Li, H.; Yang, Q.; Chen, X.; Shore, S.G. Ammonia-borane, past as prolog. J. Organomet. Chem. 2014, 751, 60-66. [CrossRef]

50. Hugues, E.W. The crystal structure of ammonia-borane, $\mathrm{H}_{3} \mathrm{NBH}_{3}$. J. Am. Chem. Soc. 1956, 78, 502-503. [CrossRef]

51. Lippert, E.L.; Lipscomb, W.N. The structure of $\mathrm{H}_{3} \mathrm{NBH}_{3}$. J. Am. Chem. Soc. 1956, 78, 503-504. [CrossRef]

52. Hoon, C.F.; Reynhardt, E.C. Molecular dynamics and structures of amine boranes of the type $\mathrm{R}_{3} \mathrm{~N}-\mathrm{BH}_{3}$ : I. X-ray investigation of $\mathrm{H}_{3} \mathrm{~N}-\mathrm{BH}_{3}$ at $295 \mathrm{~K}$ and $110 \mathrm{~K}$. J. Phys. C Solid State Phys. 1983, 16, 6129-6136. [CrossRef]

53. Huang, Y.; Huang, X.; Zhao, Z.; Li, W.; Jiang, S.; Duan, D.; Bao, K.; Zhou, Q.; Liu, B.; Cui, T. Experimental verification of the high pressure crystal structures in $\mathrm{NH}_{3} \mathrm{BH}_{3}$. J. Chem. Phys. 2014, 140, 244507. [CrossRef] [PubMed]

54. Kumar, R.S.; Ke, X.; Zhang, J.; Lin, Z.; Vogel, S.C.; Hartl, M.; Sinogeikin, S.; Daemen, L.; Cornelius, A.L.; Chen, C.; et al. Pressure induced structural changes in the potential hydrogen storage compound ammonia borane: A combined X-ray, neutron and theoretical investigation. Chem. Phys. Lett. 2010, 495, 203-207. [CrossRef]

55. Hamilton, C.W.; Baker, R.T.; Staubitz, A.; Manners, I. B-N compounds for chemical hydrogen storage. Chem. Soc. Rev. 2009, 38, 279-293. [CrossRef] 
56. Olah, G.A.; Kuhn, S.J. Propellant Compositions. U.S. Patent 3,103,782, 17 September 1963.

57. Chew, W.M.; Murfree, J.A.; Martigoni, P.; Nappier, H.A.; Ayers, O.E. Amine-Boranes as Hydrogen Generating Propellants. U.S. Patent 4,157,927, 12 June 1979.

58. $\quad$ English, W.D.; Chew, W.M. Solid Propellant Hydrogen Generator. U.S. Patent 4,315,786, 16 February 1982.

59. Artz, G.D.; Grant, L.R. Solid Propellant Hydrogen Generator. U.S. Patent 4,468,263, 28 August 1984.

60. Lee, J.G.; Weismiller, M.; Connell, T.L., Jr.; Risha, G.A.; Yetter, R.A.; Peter, G.; Son, S. Ammonia borane-based propellants. In Proceedings of the 44th AIAA/ASME/SAE/ASEE Joint Propulsion Conference and Exhibit, Hartford, CT, USA, 21-23 July 2008. [CrossRef]

61. Pfeil, M.A.; Son, S.F.; Anderson, W.E. Influence of ammonia borane on the stability of a liquid rocket combustor. J. Propuls. Power 2014, 30, 290-298. [CrossRef]

62. Yang, Y.J.; Zhao, F.Q.; Yi, J.H.; Luo, Y. Applications of hydrogen-storage materials in high-energy solid rocket propellants. Chin. J. Explos. Propellants 2015, 38, 8-14.

63. Srinivas, D.; Mitchell, L.A.; Parrish, D.A.; Shreeve, J.M. From FOX-7 to H-FOX to insensitive energetic materials with hypergolic properties. Chem. Commun. 2016, 52, 7668-7671. [CrossRef]

64. Bi, X.; Liu, J. Detonation properties of high explosives containing ammonia borane. Z. Anorg. Allg. Chem. 2016, 642, 773-777. [CrossRef]

65. Bhosale, V.A.; Jeong, J.; Kwon, S. Ignition of boron-based green hypergolic fuels with hydrogen peroxide. Fuel 2019, 255, 115729. [CrossRef]

66. Nagle, L.C.; Rohan, J.F. Ammonia borane oxidation at gold microelectrodes in alkaline solutions. J. Electrochem. Soc. 2006, 153, C773-C776. [CrossRef]

67. Andrieux, J.; Laversenne, L.; Krol, O.; Chiriac, R.; Bouajila, Z.; Tenu, R.; Counioux, J.J.; Goutaudier, C. Revision of the $\mathrm{NaBO}_{2}-\mathrm{H}_{2} \mathrm{O}$ phase diagram for optimized yield in the $\mathrm{H}_{2}$ generation through $\mathrm{NaBH}_{4}$ hydrolysis. Int. J. Hydrog. Energy 2012, 37, 5798-5810. [CrossRef]

68. Zhang, X.B.; Yan, J.M.; Han, S.; Chandra, M.; Shioyama, H.; Yasuda, K.; Kuriyama, N.; Kobayashi, T.; Xu, Q. A new fuel cell using aqueous ammonia-borane as the fuel. J. Power Sources 2008, 168, 167-171. [CrossRef]

69. Zhang, X.B.; Yan, J.M.; Han, S.; Shioyama, H.; Yasuda, K.; Kuriyama, N.; Xu, Q. A high performance anion exchange membrane-type ammonia borane fuel cell. J. Power Sources 2008, 182, 515-519. [CrossRef]

70. Demirci, U.B. Direct liquid-feed fuel cells: Thermodynamic and environmental concerns. J. Power Sources 2007, 169, 239-246. [CrossRef]

71. Yao, C.; Yang, H.; Zhuang, L.; Ai, X.; Cao, Y.; Lu, J. A preliminary study of direct borazane fuel cell. J. Power Sources 2007, 165, 125-127. [CrossRef]

72. Zhang, X.B.; Han, S.; Yan, J.M.; Shioyama, H.; Kuriyama, N.; Kobayashi, T.; Xu, Q. Electrochemical oxidation of ammonia borane on gold electrode. Int. J. Hydrog. Energy 2009, 34, 174-179. [CrossRef]

73. Molina Concha, M.B.; Chatenet, M.; Lima, F.H.B.; Ticianelli, E.A. In situ Fourier transform infrared spectroscopy and on-line differential electrochemical mass spectrometry study of the $\mathrm{NH}_{3} \mathrm{BH}_{3}$ oxidation reaction on gold electrodes. Electrochim. Acta 2013, 89, 607-615. [CrossRef]

74. Nagle, L.C.; Rohan, J.F. Direct oxidation of ammonia borane as an alternative fuel at nanoporous Au. ECS Trans. 2010, 25, 13-35.

75. Nagle, L.C.; Rohan, J.F. Nanoporous gold catalyst for direct ammonia borane fuel cells. J. Electrochem. Soc. 2011, 158, B772-B778. [CrossRef]

76. Barsuk, D.; Zadick, A.; Chatenet, M.; Georgarakis, A.; Panagiotopoulos, N.T.; Champion, Y.; Jorge, A.M., Jr. Nanoporous silver for electrocatalysis application in alkaline fuel cells. Mater. Des. 2016, 111, 528-536. [CrossRef]

77. Karabiberoğlu, Ş.U.; Koçak, Ç.C.; Koçak, S.; Dursun, Z. Polymer film supported bimetallic Au-Ag catalysts for electrocatalytic oxidation of ammonia borane in alkaline media. Nano-Micro Lett. 2016, 8, 358-370. [CrossRef] [PubMed]

78. Zhang, X.B.; Yan, J.M.; Han, S.; Shioyama, H.; Xu, Q. Magnetically recyclable Fe@Pt core-shell nanoparticles and their use as electrocatalysts for ammonia borane oxidation: The role of crystallinity of the core. J. Am. Chem. Soc. 2009, 131, 2778-2779. [CrossRef]

79. Kiran, V.; Kalidindi, S.B.; Jagirdar, B.R.; Sampath, S. Electrochemical oxidation of boron containing compounds on titanium carbide and its implications of direct fuel cells. Electrochim. Acta 2011, 56, 10493-10499. [CrossRef] 
80. Olu, P.Y.; Deschamps, F.; Caldarella, G.; Chatenet, M.; Job, N. Investigation of platinum and palladium as potential anodic catalysts for direct borohydride and ammonia borane fuel cells. J. Power Sources 2015, 297, 492-503. [CrossRef]

81. Zadick, A.; Dubau, L.; Artyushkova, A.; Serov, A.; Atanassov, P.; Chatenet, M. Nickel-based electrocatalysts for ammonia borane oxidation: Enabling materials for carbon-free-fuel direct liquid alkaline fuel cell technology. Nano Energy 2017, 37, 248-259. [CrossRef]

82. Wang, G.; Wang, H.; Chen, T.; Tan, $\mathrm{Y} . \mathrm{Ni}_{1-\mathrm{x}} \mathrm{M}_{\mathrm{X}} \mathrm{Se}_{2}(\mathrm{M}=\mathrm{Fe} ; \mathrm{Co} ; \mathrm{Cu})$ nanowires as anodes for ammonia-borane electrooxidation and the derived $\mathrm{Ni}_{1-x} \mathrm{M}_{x} \mathrm{Se}_{2-\mathrm{y}}-\mathrm{OOH}$ ultrathin nanosheets as efficient electrocatalysts for oxygen evolution. J. Mater. Chem. A 2019, 7, 16372-16386. [CrossRef]

83. Wu, C.; Zhu, J.; Wang, H.; Wang, G.; Chen, T.; Tan, Y. Porous $\mathrm{Ni}_{1-\mathrm{x}} \mathrm{Cu}_{\mathrm{x}} \mathrm{O}$ nanowire arrays as noble-metal-free high-performance catalysts for ammonia-borane electrooxidation. ACS Catal. 2020, 10, 721-735. [CrossRef]

84. Braesch, G.; Bonnefont, A.; Martin, V.; Savinova, E.R.; Chatenet, M. Borohydride oxidation reaction mechanisms and poisoning effects on $\mathrm{Au}, \mathrm{Pt}$ and Pd bulk electrodes: From model (low) to direct borohydride fuel cell operating (high) concentrations. Electrochim. Acta 2018, 273, 483-494. [CrossRef]

85. Jiang, H.L.; Singh, S.A.; Yan, J.M.; Zhang, X.B.; Xu, Q. Liquid-phase chemical hydrogen storage: Catalytic hydrogen generation under ambient conditions. ChemSusChem 2010, 3, 541-549. [CrossRef]

86. Jiang, H.L.; Xu, Q. Catalytic hydrolysis of ammonia borane for chemical hydrogen storage. Catal. Today 2011, 170, 56-63. [CrossRef]

87. Lu, Z.H.; Xu, Q. Recent progress in boron- and nitrogen-based chemical hydrogen storage. Funct. Mater. Lett. 2012, 5, 1230001. [CrossRef]

88. Zhu, Q.L.; Xu, Q. Liquid organic and inorganic chemical hydrides for high-capacity hydrogen storage. Energy Environ. Sci. 2015, 8, 478-512. [CrossRef]

89. Zhan, W.W.; Zhu, Q.L.; Xu, Q. Dehydrogenation of ammonia borane by metal nanoparticle catalysts. ACS Catal. 2016, 6, 6892-6905. [CrossRef]

90. Özkar, S. Enhancement of catalytic activity by increasing surface area in heterogeneous catalysis. Appl. Surf. Sci. 2009, 256, 1272-1277. [CrossRef]

91. Akbayrak, S.; Özkar, S. Ammonia borane as hydrogen storage materials. Int. J. Hydrog. Energy 2018, 43, 18592-18606. [CrossRef]

92. Kalidindi, S.B.; Jagirdar, B. Hydrogen generation from ammonia borane using nanocatalysts. J. Indian Inst. Sci. 2010, 90, 181-187.

93. Lu, Z.H.; Yao, Q.; Zhang, Z.; Yang, Y.; Chen, X. Nanocatalysts for hydrogen generation from ammonia borane and hydrazine borane. J. Nanomater. 2014, 2014, 729029. [CrossRef]

94. Umegaki, T.; Xu, Q.; Kojima, Y. Porous materials for hydrolytic dehydrogenation of ammonia borane. Materials 2015, 8, 4512-4534. [CrossRef]

95. Luconi, L.; Tuci, G.; Giambastiani, G.; Rossin, A.; Peruzzini, M. $\mathrm{H}_{2}$ production from lightweight inorganic hydrides catalyzed by 3d transition metals. Int. J. Hydrog. Energy 2019, 44, 25746-25776. [CrossRef]

96. Alpaydın, C.Y.; Gülbay, S.A.; Colpan, C.O. A review on the catalysts used for hydrogen production from ammonia borane. Int. J. Hydrog. Energy 2020, 45, 3414-3434. [CrossRef]

97. Fu, F.; Wang, C.; Wang, Q.; Martinez-Villacorta, A.M.; Escobar, A.; Ching, H.; Wang, X.; Moya, S.; Salmon, L.; Fouquet, E.; et al. Highly selective and sharp volcano-type synergistic $\mathrm{Ni}_{2} \mathrm{Pt} @ Z$ ZIF-8-catalyzed hydrogen evolution from ammonia borane hydrolysis. J. Am. Chem. Soc. 2018, 140, 10034-10042. [CrossRef] [PubMed]

98. Zhang, H.; Huang, M.; Wen, J.; Li, Y.; Li, A.; Zhang, L.; Ali, A.M.; Li, Y. Sub-3 nm Rh nanoclusters confined within a metal-organic framework for enhanced hydrogen generation. Chem. Commun. 2019, 55, 4699-4702. [CrossRef] [PubMed]

99. Qi, B.; Du, L.; Yao, F.; Xu, S.; Deng, X.; He, S.; Zhanng, H.; Zhou, X. Shape-controlled dodecaborate supramolecular organic-framework-supported ultrafine trimetallic PtCoNi for catalytic hydrolysis of ammonia borane. ACS Appl. Mater. Interf. 2019, 11, 23445-23453. [CrossRef]

100. Sarıca, E.; Akbayrak, S.; Özkar, S. Ruthenium(0) nanoparticles supported on silica coated $\mathrm{Fe}_{3} \mathrm{O}_{4}$ as magnetically separable catalysts for hydrolytic dehydrogenation of ammonia borane. Int. J. Hydrog. Energy 2018, 43, 15124-15134.

101. Umegaki, T.; Yabuuchi, A.; Yoshida, N.; Xu, Q.; Kojima, Y. In situ synthesized hollow spheres of a silica-ruthenium-nickel composite catalyst for the hydrolytic dehydrogenation of ammonia borane. New J. Chem. 2019, 44, 450-455. [CrossRef] 
102. Chen, M.; Xiong, R.; Cui, X.; Wang, Q.; Liu, X. SiO 2 -encompassed Co@N-doped porous carbon assemblies as recyclable catalysts for efficient hydrolysis of ammonia borane. Langmuir 2019, 35, 671-677. [CrossRef]

103. Toyama, N.; Nikura, N.; Ito, I.; Umegaki, T.; Kojima, Y. Synthesis of mesoporous silica-zirconia composite hollow spheres with enhanced activity toward hydrolysis of ammonia borane. Microp. Mesop. Mater. 2020, 294, 109839. [CrossRef]

104. Du, X.; Tai, Y.; Liu, H.; Zhang, J. One-step synthesis of reduced graphene oxide supported CoW nanoparticles as efficient catalysts for hydrogen generation from $\mathrm{NH}_{3} \mathrm{BH}_{3}$. React. Kinet. Mech. Catal. 2018, 125, 171-181. [CrossRef]

105. Zhou, Y.H.; Zhang, Z.; Wang, S.; Williams, N.; Cheng, Y.; Liu, S.; Gu, J. rGO supported PfNi-CeO 2 nanocomposite as an efficient catalyst for hydrogen evolution from the hydrolysis of $\mathrm{NH}_{3} \mathrm{BH}_{3}$. Int. J. Hydrog. Energy 2018, 43, 18745-18753. [CrossRef]

106. Xu, M.; Huai, X.; Zhang, H. Highly dispersed CuCo nanoparticles supported on reduced graphene oxide as high-activity catalysts for hydrogen evolution from ammonia borane hydrolysis. J. Nanopart. Res. 2018, 20, 329. [CrossRef]

107. Uzundurukan, A.; Devrim, Y. Carbon nanotube-graphene hybrid supported platinum as an effective catalyst for hydrogen generation from hydrolysis of ammonia borane. Int. J. Hydrog. Energy 2019, 44, 26773-26782. [CrossRef]

108. Shang, Y.; Feng, A.; Wang, Y.; Sun, C.; Zhong, J. Carbon nitride supported $\mathrm{Ni}_{0.5} \mathrm{C}_{0.5} \mathrm{O}$ nanoparticles with strong interfacial interaction to enhance the hydrolysis of ammonia borane. RSC Adv. 2019, 9, 11552-11557. [CrossRef]

109. Zhou, X.; Meng, X.F.; Wang, J.M.; Shang, N.Z.; Feng, T.; Gao, Z.Y.; Zhang, H.X.; Ding, X.L.; Gao, S.T.; Feng, C.; et al. Boron nitride supported NiCoP nanoparticles as noble metal-free catalyst for highly efficient hydrogen generation from ammonia borane. Int. J. Hydrog. Energy 2019, 44, 4764-4770. [CrossRef]

110. Gao, M.; Yu, Y.; Yang, W.; Li, J.; Xu, S.; Feng, M.; Li, H. Ni nanoparticles supported on graphitic carbon nitride as visible light catalysts for hydrolytic dehydrogenation of ammonia borane. Nanoscale 2019, 11, 3506-3513. [CrossRef]

111. Li, C.; Wang, D.; Wang, Y.; Li, G.; Hu, G.; Shiwei, W.; Cao, Z.; Zhang, K. Enhanced catalytic activity of the nanostructured Co-W-B film catalysts for hydrogen evolution from the hydrolysis of sodium borohydride. J. Colloid Interf. Sci. 2018, 524, 25-32. [CrossRef]

112. Rakap, M.; Abay, B.; Tunç, N. Hydrolysis of ammonia borane and hydrazine borane by poly(N-vinyl-2-pyrrolidone)-stabilized CoPd nanoparticles for chemical hydrogen storage. Turk. J. Chem. 2017, 41, 221-232. [CrossRef]

113. Zhang, J.; Chen, W.; Ge, H.; Chen, C.; Yan, W.; Gao, Z.; Gan, J.; Zhang, B.; Duan, X.; Qin, Y. Synergistic effects in atomic-layer-deposited PtCox/CNTs catalysts enhancing hydrolytic dehydrogenation of ammonia borane. Appl. Catal. B Env. 2018, 235, 256-263. [CrossRef]

114. Coşkuner Filiz, B.; Kantürk Figen, A.; Pişkin, S. The remarkable role of metal promoters on the catalytic activity of $\mathrm{Co}-\mathrm{Cu}$ based nanoparticles for boosting hydrogen evolution: Ammonia borane hydrolysis. Appl. Catal. B Env. 2018, 238, 365-380. [CrossRef]

115. Coşkuner Filiz, B.; Kantürk Figen, A. Polymeric and metal oxide structured nanofibrous composites fabricated by electrospinning as highly efficient hydrogen evolution catalyst. J. Colloid Interf. Sci. 2019, 533, 82-94.

116. Feng, X.; Zhao, Y.; Liu, D.; Mo, Y.; Liu, Y.; Chen, X.; Yan, W.; Jin, X.; Chen, B.; Duan, X.; et al. Towards high activity of hydrogen production from ammonia borane over efficient non-noble $\mathrm{Ni}_{5} \mathrm{P}_{4}$ catalyst. Int. J. Hydrog. Energy 2018, 43, 17112-17120. [CrossRef]

117. Qu, X.; Jiang, R.; Li, Q.; Zeng, F.; Zheng, X.; Xu, Z.; Chen, C.; Peng, J. The hydrolysis of ammonia borane catalyzed by NiCoP/OPC-300 nanocatalysts: High selectivity and efficiency, and mechanism. Green Chem. 2019, 21, 850-860. [CrossRef]

118. Yang, C.; Men, Y.; Xu, Y.; Liang, L.; Cai, P.; Luo, W. In situ synthesis of NiCoP nanoparticles supported on reduced graphene oxide for the catalytic hydrolysis of ammonia borane. ChemPlusChem 2019, 84, 382-386. [CrossRef] [PubMed]

119. Lu, R.; Xu, C.; Wang, Q.; Wang, Y.; Zhang, Y.; Gao, D.; Bi, J.; Fan, G. Ruthenium nanoclusters distributed on phosphorus-doped carbon derived from hypercrosslinked polymer networks for highly efficient hydrolysis of ammonia-borane. Int. J. Hydrog. Energy 2018, 43, 18253-18260. [CrossRef] 
120. Zhong, F.; Wang, Q.; Xu, C.; Yang, Y.; Wang, Y.; Zhang, Y.; Gao, D.; Bi, J.; Fan, G. Ultrafine and highly dispersed Ru nanoparticles supported on nitrogen-doped carbon nanosheets: Efficient catalysts for ammonia borane hydrolysis. Appl. Surf. Sci. 2018, 455, 326-332. [CrossRef]

121. Cui, Z.; Guo, Y.; Feng, Z.; Xu, D.; Ma, J. Ruthenium nanoparticles supported on nitrogen-doped carbon as a highly efficient catalyst for hydrogen evolution from ammonia borane. New J. Chem. 2019, 43, 4377-4384. [CrossRef]

122. Akbayrak, S.; Özçifçi, Z.; Tabak, A. Noble metal nanoparticles supported on activated carbon: Highly recyclable catalysts in hydrogen generation from the hydrolysis of ammonia borane. J. Colloid Interf. Sci. 2019, 546, 324-332. [CrossRef]

123. Zhou, Z.H.; Wang, S.; Zhang, Z.; Williams, N.; Cheng, Y.; Gu, J. Hollow nickel-cobalt layered double hydroxide supported palladium catalysts with superior hydrogen evolution activity for hydrolysis of ammonia borane. ChemCatChem 2018, 10, 3206-3213. [CrossRef]

124. Gil-San-Millan, R.; Grau-Atienza, A.; Johnson, D.T.; Rico-Francés, S.; Serrano, E.; Garcia-Martinez, J. Improving hydrogen production from the hydrolysis of ammonia borane by using multifunctional catalysts. Int. J. Hydrog. Energy 2018, 43, 17100-17111. [CrossRef]

125. Jia, H.; Chen, X.; Song, X.; Zheng, X.; Guan, X.; Liu, P. Graphitic carbon nitride-chitosan composites-anchored palladium nanoparticles as high-performance catalyst for ammonia borane hydrolysis. Int. J. Energy Res. 2019, 43, 535-543. [CrossRef]

126. Çelik Kazici, H.; Yıldız, F.; İzgi, M.S.; Ulas, B.; Kıvrak, H. Novel activated carbon supported trimetallic PdCoAg nanoparticles as efficient catalysts for the hydrolytic dehydrogenation of ammonia borane. Int. J. Hydrog. Energy 2019, 44, 10561-10572. [CrossRef]

127. Akbayrak, S.; Tonbul, Y.; Özkar, S. Magnetically separable $\mathrm{Rh}^{0} / \mathrm{Co}_{3} \mathrm{O}_{4}$ nanocatalyst provides over a million turnovers in hydrogen release from ammonia borane. ACS Sust. Chem. Eng. 2020, 8, 4216-4224. [CrossRef]

128. Brockman, A.; Zheng, Y.; Gore, J. A study of catalytic hydrolysis of concentrated ammonia borane solutions. Int. J. Hydrog. Energy 2010, 35, 7350-7356. [CrossRef]

129. Lai, Q.; Aguey-Zinsou, F.K.; Demirci, U.B. Nanosizing ammonia borane with nickel - An all-solid and all-in-one approach for $\mathrm{H}_{2}$ generation by hydrolysis. Int. J. Hydrog. Energy 2018, 43, 14498-14506. [CrossRef]

130. Keskin, E.; Coşkuner Filiz, B.; Kılıç Depren, S.; Kantürk Figen, A. Recommendations for ammonia borane composite pellets as a hydrogen storage medium. Int. J. Hydrog. Energy 2018, 43, 20354-20371. [CrossRef]

131. Chandra, M.; Xu, Q. Room temperature hydrogen generation from aqueous ammonia-borane using noble metal nano-clusters as highly active catalysts. J. Power Sources 2007, 168, 135-142. [CrossRef]

132. Chrysostomou, D.; Flowers, J.; Zaera, F. The thermal chemistry of ammonia on Ni(110). Surf. Sci. 1999, 439, 34-48. [CrossRef]

133. Liu, C.H.; Wu, Y.C.; Chou, C.C.; Chen, B.H.; Hsueh, C.L.; Ku, J.R.; Tsau, F. Hydrogen generated from hydrolysis of ammonia borane using cobalt and ruthenium based catalysts. Int. J. Hydrog. Energy 2012, 37, 2950-2959. [CrossRef]

134. Lan, R.; Tao, S. Ammonia as a suitable fuel for fuel cells. Front. Energy Res. 2014, 2, 35. [CrossRef]

135. Petit, E.; Miele, P.; Demirci, U.B. By-product carrying humidified hydrogen: An underestimated issue in the field of hydrolysis of sodium borohydride $\mathrm{NaBH}_{4}$. ChemSusChem 2016, 9, 1777-1780. [CrossRef]

136. Lapena-Rey, N.; Blanco, J.A.; Ferreyra, E.; Lemus, J.L.; Pereira, S.; Serrot, E. A fuel cell powered unmanned aerial vehicle for low altitude surveillance missions. Int. J. Hydrog. Energy 2017, 42, 6926-6940. [CrossRef]

137. Kildahl, N.K. Bond energy data summarized. J. Chem. Educ. 1995, 72, 423-424. [CrossRef]

138. Andersson, J.; Grönkvist, S. Large-scale storage of hydrogen. Int. J. Hydrog. Energy 2019, 44, 11901-11919. [CrossRef]

139. Mohajeri, N.; T-Raissi, A.; Adebiyi, O. Hydrolytic cleavage of ammonia-borane complex for hydrogen production. J. Power Sources 2007, 167, 482-485. [CrossRef]

140. Spessard, J.E. Investigations of borane equilibria in neutral salt solutions. J. Inorg. Nucl. Chem. 1970, 32, 2607-2613. [CrossRef]

141. Mesmer, R.E.; Baes, C.F.; Sweeton, F.H. Acidity measurements at elevated temperatures. VI. Boric acid equilibria. Inorg. Chem. 1972, 11, 537-543. [CrossRef]

142. Zhou, Y.Q.; Fang, C.H.; Fang, Y.; Zhu, F.Y.; Cao, L.D. Polyborates in aqueous borate solution at 298.15 K. Asian J. Chem. 2012, 24, 29-32. 
143. Rachiero, G.P.; Demirci, U.B.; Miele, P. Bimetallic RuCo and RuCu catalysts supported on $\gamma-\mathrm{Al}_{2} \mathrm{O}_{3}$. A comparative study of their activity in hydrolysis of ammonia-borane. Int. J. Hydrog. Energy 2011, 36, 7051-7065. [CrossRef]

144. Valero-Pedraza, M.J.; Alligier, D.; Petit, E.; Cot, D.; Granier, D.; Adil, K.; Yot, P.G.; Demirci, U.B. Diammonium tetraborate dihydrate as hydrolytic by-product of ammonia borane in aqueous alkaline conditions. Int. J. Hydrog. Energy 2020, 45, 9926-9935. [CrossRef]

145. Anastas, P.; Eghbali, N. Green chemistry: Principles and practice. Chem. Soc. Rev. 2010, 39, $301-312$. [CrossRef]

146. Liu, C.H.; Chen, B.H. The concept about the regeneration of spent borohydrides and used catalysts from green electricity. Materials 2015, 8, 3456-3466. [CrossRef]

147. Monteverde, M.; Magistri, L. Hydrogen from sodium borohydride and fossil source: An energetic and economical comparison. Int. J. Hydrog. Energy 2012, 37, 5452-5460. [CrossRef]

148. Özkar, S. Transition metal nanoparticle catalysts in releasing hydrogen from the methanolysis of ammonia borane. Int. J. Hydrog. Energy 2020, 45, 7881-7891. [CrossRef]

149. Kalidindi, S.B.; Sanyal, U.; Jagirdar, B.R. Nanostructured $\mathrm{Cu}$ and $\mathrm{Cu} @ \mathrm{Cu}_{2} \mathrm{O}$ core shell catalysts for hydrogen generation from ammonia-borane. Phys. Chem. Chem. Phys. 2008, 10, 5870-5874. [CrossRef] [PubMed]

150. Yao, Q.; Huang, M.; Lu, Z.H.; Yang, Y.; Zhang, Y.; Chen, X.; Yang, Z. Methanolysis of ammonia borane by shape-controlled mesoporous copper nanostructures for hydrogen generation. Dalton Trans. 2014, 44, 1070-1076. [CrossRef] [PubMed]

151. Yurderi, M.; Bulut, A.; Ertaş, İ.E.; Zahmakıran, M.; Kaya, M. Supported copper-copper oxide nanoparticles as active; stable and low-cost catalyst in the methanolysis of ammonia-borane for chemical hydrogen storage. Appl. Catal. B Env. 2015, 165, 169-175. [CrossRef]

152. Chen, Q.Q.; Li, Q.; Hou, C.C.; Wang, C.; Peng, C.Y.; Lopez, N.; Chen, Y. Enhancing electrostatic interactions to activate polar molecules: Ammonia borane methanolysis on $\mathrm{Cu} / \mathrm{Co}(\mathrm{OH})_{2}$ nanohybrid. Catal. Sci. Technol. 2019, 9, 2828-2835. [CrossRef]

153. Kalidindi, S.B.; Vernekar, A.A.; Jagirdar, B.R. Co- $\mathrm{Co}_{2} \mathrm{~B}, \mathrm{Ni}-\mathrm{Ni}_{3} \mathrm{~B}$ and $\mathrm{Co}-\mathrm{Ni}-\mathrm{B}$ nanocomposites catalyzed ammonia-borane methanolysis for hydrogen generation. Phys. Chem. Chem. Phys. 2009, 11, 770-775. [CrossRef]

154. Sun, D.; Mazumder, V.; Metin, Ö.; Sun, S. Methanolysis of ammonia borane by CoPd nanoparticles. ACS Catal. 2012, 2, 1290-1295. [CrossRef]

155. Murathan, H.B.; Özkan, G.; Akkuş, M.S.; Özgür, D.Ö.; Özkan, G. Hydrogen production from the methanolysis of ammonia borane by $\mathrm{Pd}-\mathrm{Co} / \mathrm{Al}_{2} \mathrm{O}_{3}$ coated monolithic catalyst. Int. J. Hydrog. Energy 2018, 43, 10728-10733. [CrossRef]

156. Özhava, D.; Kiliçaslan, N.Z.; Özkar, S. PVP-stabilized nickel(0) nanoparticles as catalyst in hydrogen generation from the methanolysis of hydrazine borane or ammonia borane. Appl. Catal. B Env. 2015, 162, 573-582. [CrossRef]

157. Kantürk Figen, A. Improved catalytic performance of metal oxide catalysts fabricated with electrospinning in ammonia borane methanolysis for hydrogen production. Int. J. Hydrog. Energy 2019, 44, 28451-28462. [CrossRef]

158. Erdoğan, H.; Metin, Ö.; Özkar, S. In situ-generated PVP-stabilized palladium(0) nanocluster catalyst in hydrogen generation from the methanolysis of ammonia-borane. Phys. Chem. Chem. Phys. 2009, 11, 10519-10525. [CrossRef] [PubMed]

159. Karataş, Y.; Gülcan, M.; Çelebi, M.; Zahmakıran, M. Pd(0) nanoparticles decorated on graphene nanosheets (GNS): SynthesiS, definition and testing of the catalytic performance in the methanolysis of ammonia borane at room conditions. ChemistrySelect 2017, 2, 9628-9635. [CrossRef]

160. Eghbali, P.; Gürbüz, M.U.; Ertürk, A.S.; Metin, Ö. In situ synthesis of dendrimer-encapsulated palladium(0) nanoparticles as catalysts for hydrogen production from the methanolysis of ammonia borane. Int. J. Hydrog. Energy 2020, 45. in press. [CrossRef]

161. Çalışkan, S.; Zahmakıran, M.; Özkar, S. Zeolite confined rhodium(0) nanoclusters as highly active; reusable; and long-lived catalyst in the methanolysis of ammonia-borane. Appl. Catal. B Env. 2010, 93, 387-394. [CrossRef] 
162. Özhava, D.; Özkar, S. Rhodium(0) nanoparticles supported on hydroxyapatite nanospheres and further stabilized by dihydrogen phosphate ion: A highly active catalyst in hydrogen generation from the methanolysis of ammonia borane. Int. J. Hydrog. Energy 2015, 40, 10491-10501. [CrossRef]

163. Özhava, D.; Özkar, S. Nano-alumina-supported rhodium $(0)$ nanoparticles as catalyst in hydrogen generation from the methanolysis of ammonia borane. Mol. Catal. 2017, 439, 50-59. [CrossRef]

164. Luo, W.; Cheng, W.; Hu, M.; Wang, Q.; Cheng, X.; Zhang, Y.; Wang, Y.; Gao, D.; Bi, J.; Fan, G. Ultrahigh catalytic activity of L-proline-functionalized Rh nanoparticles for methanolysis of ammonia borane. ChemSusChem 2019, 12, 535-541. [CrossRef]

165. Dai, H.B.; Kang, X.D.; Wang, P. Ruthenium nanoparticles immobilized in montmorillonite used as catalyst for methanolysis of ammonia borane. Int. J. Hydrog. Energy 2010, 35, 10317-10323. [CrossRef]

166. Erdoğan, H.; Metin, Ö.; Özkar, S. Hydrogen generation from the methanolysis of ammonia borane catalyzed by in situ generated polymer stabilized ruthenium(0) nanoclusters. Catal. Today 2011, 170, 93-98. [CrossRef]

167. Peng, S.; Liu, J.; Zhang, J.; Wang, F. An improved preparation of graphene supported ultrafine ruthenium(0) NPs: Very active and durable catalysts for $\mathrm{H}_{2}$ generation from methanolysis of ammonia borane. Int. J. Hydrog. Energy 2015, 40, 10856-10866. [CrossRef]

168. Ramachandran, P.V.; Raju, B.C.; Gagare, P.D. One-pot synthesis of ammonia-borane and trialkylamine-boranes from trimethyl borate. Org. Lett. 2012, 14, 6119-6121. [CrossRef] [PubMed]

169. Mayer, E. Conversion of dihydridodiammineboron(III) borohydride to ammonia-borane without hydrogen evolution. Inorg. Chem. 1973, 12, 1954-1955. [CrossRef]

170. Rassat, S.D.; Aardahl, C.L.; Autrey, T.; Smith, R.S. Thermal stability of ammonia borane: A case study for exothermic hydrogen storage materials. Energy Fuels 2010, 24, 2596-2606. [CrossRef]

171. Bluhm, M.E.; Bradley, M.G.; Butterick, R., III; Kusari, U.; Sneddon, L.G. Amineborane-based chemical hydrogen storage: Enhanced ammonia borane dehydrogenation in ionic liquids. J. Am. Chem. Soc. 2006, 128, 7748-7749. [CrossRef] [PubMed]

172. Baitalow, F.; Baumann, J.; Wolf, G.; Jaenicke-Rössler, A.; Leitner, G. Thermal decomposition of B-N-H compounds investigated by using combined thermoanalytical methods. Thermochim. Acta 2002, 391, 159-168. [CrossRef]

173. Wolf, G.; Baumann, J.; Baitalow, F.; Hoffmann, F.P. Calorimetric process monitoring of thermal decomposition of B-N-H compounds. Thermochim. Acta 2000, 343, 19-25. [CrossRef]

174. Stowe, A.C.; Shaw, W.J.; Linehan, J.C.; Schmid, B.; Autrey, T. In situ solid state ${ }^{11}$ B MAS-NMR studies of the thermal decomposition of ammonia borane: Mechanistic studies of the hydrogen release pathways from a solid state hydrogen storage material. Phys. Chem. Chem. Phys. 2007, 9, 1831-1836. [CrossRef]

175. Heldebrant, D.J.; Karkamkar, A.; Hess, N.J.; Bowden, M.; Rassat, S.; Zheng, F.; Rappe, K.; Autrey, T. The effects of chemical additives on the induction phase in solid-state thermal decomposition of ammonia borane. Chem. Mater. 2008, 20, 5332-5336. [CrossRef]

176. Hu, M.G.; Geanangel, R.A.; Wendlandt, W.W. The thermal decomposition of ammonia borane. Thermochim. Acta 1978, 23, 249-255. [CrossRef]

177. Al-Kukhun, A.; Hwang, H.T.; Varma, A. Mechanistic studies of ammonia borane dehydrogenation. Int. J. Hydrog. Energy 2013, 38, 169-179. [CrossRef]

178. Kang, X.; Fang, Z.; Kong, L.; Cheng, H.; Yao, X.; Lu, G.; Wang, P. Ammonia borane destabilized by lithium hydride: An advanced on-board hydrogen storage material. Adv. Mater. 2008, 20, 2756-2759. [CrossRef] [PubMed]

179. Sit, V.; Geanangel, R.A.; Wendlandt, W.W. The thermal dissociation of $\mathrm{NH}_{3} \mathrm{BH}_{3}$. Thermochim. Acta 1987, 113, 379-382. [CrossRef]

180. Frueh, S.; Kellett, R.; Mallery, C.; Moller, T.; Willis, W.S.; King'ondu, C.; Suib, S.L. Pyrolytic decomposition of ammonia borane to boron nitride. Inorg. Chem. 2011, 50, 783-792. [CrossRef]

181. Baumann, J.; Baitalow, F.; Wolf, G. Thermal decomposition of polymeric aminoborane $\left(\mathrm{H}_{2} \mathrm{BNH}_{2}\right)_{\mathrm{x}}$ under hydrogen release. Thermochim. Acta 2005, 430, 9-14. [CrossRef]

182. Wolstenholme, D.J.; Traboulsee, K.T.; Hua, Y.; Calhoun, L.A.; McGrady, G.S. Thermal desorption of hydrogen from ammonia borane: Unexpected role of homopolar B-H...H-B interactions. Chem. Commun. 2012, 48, 2597-2599. [CrossRef]

183. Roy, B.; Hajari, A.; Manna, J.; Sharma, P. Supported ammonia borane decomposition through enhanced homopolar B-B coupling. Dalton Trans. 2018, 47, 6570-6579. [CrossRef] 
184. Petit, J.F.; Demirci, U.B. Mechanistic insights into dehydrogenation of partially deuterated ammonia borane $\mathrm{NH}_{3} \mathrm{BD}_{3}$ being heating to $200{ }^{\circ} \mathrm{C}$. Inorg. Chem. 2019, 58, 489-494. [CrossRef]

185. Petit, J.F.; Dib, E.; Gaveau, P.; Miele, P.; Alonso, B.; Demirci, U.B. ${ }^{11}$ B MAS NMR study of the thermolytic dehydrocoupling of two ammonia boranes upon the release of one equivalent of $\mathrm{H}_{2}$ at isothermal conditions. ChemistrySelect 2017, 2, 9396-9401. [CrossRef]

186. Summerscales, O.T.; Gordon, J.C. Regeneration of ammonia borane from spent fuel materials. Dalton Trans. 2013, 42, 10075-10084. [CrossRef] [PubMed]

187. Kobayashi, T.; Gupta, S.; Caporini, M.A.; Pecharsky, V.A.; Pruski, M. Mechanism of solid-state thermolysis of ammonia borane: A ${ }^{15} \mathrm{~N}$ NMR study using fast magic-ange spinning and dynamic nuclear polarization. J. Phys. Chem. C 2014, 118, 19548-19555. [CrossRef]

188. Nakagawa, T.; Burrell, A.A.; Del Sesto, R.E.; Janicke, M.T.; Nekimken, A.L.; Purdy, G.M.; Paik, B.; Zhong, R.Q.; Semelsberger, T.A.; Dais, B.L. Physical, structural, and dehydrogenation properties of ammonia borane in ionic liquids. RSC Adv. 2014, 4, 21681-21687. [CrossRef]

189. Himmelberger, D.W.; Alden, L.R.; Bluhm, M.E.; Sneddon, L.G. Ammonia borane hydrogen release in ionic liquids. Inorg. Chem. 2009, 48, 9883-9889. [CrossRef] [PubMed]

190. Basu, S.; Zheng, Y.; Gore, J.P. An experimental study of neat and ionic liquid-aided ammonia borane thermolysis. J. Power Sources 2011, 196, 734-740. [CrossRef]

191. Ahluwalia, R.A.; Peng, J.A.; Hua, T.Q. Hydrogen release from ammonia borane dissolved in an ionic liquid. Int. J. Hydrog. Energy 2011, 36, 15689-15697. [CrossRef]

192. Sahler, S.; Strum, S.; Kessler, M.T.; Prechtl, M.H.G. The role of ionic liquids in hydrogen storage. Chem. Eur. J. 2014, 20, 8934-8941. [CrossRef]

193. Valero-Pedraza, M.J.; Martin-Cortes, A.; Navarrete, A.; Bermejo, M.D.; Martín, A. Kinetics of hydrogen release from dissolutions of ammonia borane in different ionic liquids. Energy 2015, 91, 742-750. [CrossRef]

194. Koska, J.F.; Schellenberg, R.; Baitalow, F.; Smolinka, T.; Mertens, F. Concentration-dependent dehydrogenation of ammonia-borane/triglyme mixtures. Eur. J. Inorg. Chem. 2012, 2012, 49-54. [CrossRef]

195. Shaw, W.J.; Linehan, J.C.; Szymczak, N.A.; Heldebrant, D.J.; Yonker, C.; Camaioni, D.M.; Baker, R.T.; Autrey, T. In situ multinuclear NMR spectroscopic studies of the thermal decomposition of ammonia borane in solution. Angew. Chem. Int. Ed. 2008, 47, 7493-7496. [CrossRef]

196. Denney, M.C.; Pons, V.; Hebden, T.J.; Heinekey, D.M.; Goldberg, K.I. Efficient catalysis of ammonia borane dehydrogenation. J. Am. Chem. Soc. 2006, 128, 12048-12049. [CrossRef] [PubMed]

197. Rossin, A.; Caporali, M.; Gonsalvi, L.; Guerri, A.; Lledós, A.; Peruzzini, M.; Zanobini, F. Selective B-H versus $\mathrm{N}-\mathrm{H}$ bond activation in ammonia borane by [Ir(dppm) $\left.)_{2}\right]$ OTf. Eur. J. Inorg. Chem. 2009, 2009, 3055-3059. [CrossRef]

198. Keaton, R.J.; Blacquiere, J.M.; Baker, R.T. Base metal catalyzed dehydrogenation of ammonia-borane for chemical hydrogen storage. J. Am. Chem. Soc. 2007, 129, 1844-1845. [CrossRef] [PubMed]

199. Conley, B.L.; Williams, T.J. Dehydrogenation of ammonia-borane by Shvo's catalyst. Chem. Commun. 2010, 46, 4815-4817. [CrossRef] [PubMed]

200. Baker, R.T.; Gordon, J.C.; Hamilton, C.W.; Henson, N.J.; Lin, P.H.; Maguire, S.; Murugesu, M.; Scott, B.L.; Smythe, N.C. Iron complex-catalyzed ammonia-borane dehydrogenation. A potential route toward B-N-containing polymer motifs using earth-abundant metal catalysts. J. Am. Chem. Soc. 2012, 134, 5598-5609. [CrossRef]

201. Glüer, A.; Förster, M.; Celinski, V.R.; Schmedt Auf Der Günne, J.; Holthausen, M.C.; Schneider, S. Highly active iron catalyst for ammonia borane dehydrocoupling at room temperature. ACS Catal. 2015, 5, 7214-7217. [CrossRef]

202. Marziale, A.N.; Friedrich, A.; Klopsch, I.; Drees, M.; Celinski, V.R.; Schmedt Auf Der Günne, J.; Schneider, S. The mechanism of borane-amine dehydrocoupling with bifunctional ruthenium catalysts. J. Am. Chem. Soc. 2013, 135, 13342-13355. [CrossRef]

203. Rossin, A.; Rossi, A.; Peruzzini, M.; Zanobini, F. Chemical hydrogen storage: Ammonia borane dehydrogenation catalyzed by $\mathrm{NP}_{3}$ ruthenium hydrides $\left(\mathrm{NP}_{3}=\mathrm{N}\left(\mathrm{CH}_{2} \mathrm{CH}_{2} \mathrm{PPh}_{2}\right)_{3}\right)$. ChemPlusChem 2014, 79, 1316-1325. [CrossRef]

204. Zhang, X.; Kam, L.; Williams, T.J. Dehydrogenation of ammonia borane through the third equivalent of hydrogen. Dalton Trans. 2016, 45, 7672-7677. [CrossRef] 
205. Kim, S.A.; Han, W.S.; Kim, T.J.; Kim, T.Y.; Nam, S.W.; Mitoraj, M.; Piekos, L.; Michalak, A.; Hwang, S.J.; Kang, S.O. Palladium catalysts for dehydrogenation of ammonia borane with preferential B-H activation. J. Am. Chem. Soc. 2010, 132, 9954-9955. [CrossRef]

206. Rossin, A.; Bottari, G.; Lozana-Vila, A.M.; Paneque, M.; Peruzzini, M.; Rossi, A.; Zanobini, F. Catalytic amine-borane dehydrogenation by a PCP-pincer palladium complex: A combined experimental and DFT analysis of the reaction mechanism. Dalton Trans. 2013, 42, 3533-3541. [CrossRef] [PubMed]

207. Rossin, A.; Peruzzini, M. Ammonia-borane and amine-borane dehydrogenation mediated by complex metal composites. Chem. Rev. 2016, 116, 8848-8872. [CrossRef] [PubMed]

208. Zhang, X.; Kam, L.; Trerise, R.; Williams, T.J. Ruthenium-catalyzed ammonia borane dehydrogenation: Mechanism and utility. Acc. Chem. Res. 2017, 50, 86-95. [CrossRef] [PubMed]

209. Shimbayashi, T.; Fujita, K.I. Metal-catalyzed hydrogenation and dehydrogenation reactions for efficient hydrogen storage. Tetrahedron 2020, 2020, 130946. [CrossRef]

210. Hasenbeck, M.; Becker, J.; Gellrich, U. Efficient organocatalytic dehydrogenation of ammonia borane. Angew. Chem. Int. Ed. 2020, 59, 1590-1594. [CrossRef]

211. Benedetto, S.D.; Carewska, M.; Cento, C.; Gislon, P.; Pasquali, M.; Scaccia, S.; Prosini, P.P. Effect of milling and doping on decomposition of $\mathrm{NH}_{3} \mathrm{BH}_{3}$ complex. Thermochim. Acta 2006, 441, 184-190. [CrossRef]

212. He, T.; Xiong, Z.; Wu, G.; Chu, H.; Wu, C.; Zhang, T.; Chen, P. Nanosized Co- and Ni-catalyzed ammonia borane for hydrogen storage. Chem. Mater. 2009, 21, 2315-2318. [CrossRef]

213. Benzouaa, R.; Demirci, U.B.; Chiriac, R.; Toche, F.; Miele, P. Metal chloride-doped ammonia borane thermolysis: Positive effect on induction period as well as hydrogen and borazine release. Thermochim. Acta 2010, 509, 81-86. [CrossRef]

214. Toche, F.; Chiriac, R.; Demirci, U.B.; Miele, P. Ammonia borane thermolytic decomposition in the presence of metal (II) chlorides. Int. J. Hydrog. Energy 2012, 37, 6749-6755. [CrossRef]

215. Chiriac, R.; Toche, F.; Demirci, U.B.; Miele, P. Instability of the $\mathrm{CuCl}_{2}-\mathrm{NH}_{3} \mathrm{BH}_{3}$ mixture followed by TGA and DSC. Thermochim. Acta 2013, 567, 100-106. [CrossRef]

216. Chiriac, R.; Toche, F.; Demirci, U.B.; Krol, O.; Miele, P. Ammonia borane decomposition in the presence of cobalt halides. Int. J. Hydrog. Energy 2011, 36, 12955-12964. [CrossRef]

217. Li, Y.; Fang, F.; Song, Y.; Li, Y.; Zhang, Q.; Ouyang, L.; Zhu, M.; Sun, D. Enhanced dehydrogenation of ammonia borane by reaction with alkaline earth metal chlorides. Int. J. Hydrog. Energy 2012, 37, 4274-4279. [CrossRef]

218. Biliskov, N.; Vojta, D.; Kótai, L.; Szilágyi, I.M.; Hunyadi, D.; Pasinszki, T.; Grgac, S.F.; Borgschulte, A.; Züttel, A. High influence of potassium bromide on thermal decomposition of ammonia borane. J. Phys. Chem. C 2016, 120, 25276-25288. [CrossRef]

219. Kang, X.; Ma, L.; Fang, Z.; Gao, L.; Luo, J.; Wang, S.; Wang, P. Promoted hydrogen release from ammonia borane by mechanically milling with magnesium hydride: A new destabilizing approach. Phys. Chem. Chem. Phys. 2009, 11, 2507-2513. [CrossRef] [PubMed]

220. Luo, J.; Kang, X.; Wang, P. Renewed insight into the promoting mechanism of magnesium hydride on ammonia borane. ChemPhysChem 2010, 11, 2152-2157. [CrossRef]

221. Weng, B.; Wu, Z.; Li, Z.; Leng, H. Dehydrogenation performance of $\mathrm{NH}_{3} \mathrm{BH}_{3}$ with $\mathrm{Mg}_{2} \mathrm{NiH}_{4}$ addition. Thermochim. Acta 2011, 524, 23-28. [CrossRef]

222. Kang, X.D.; Luo, J.H.; Wang, P. Efficient and highly rapid hydrogen release from ball-milled $3 \mathrm{NH}_{3} \mathrm{BH}_{3} / \mathrm{MMgH}_{3}$ $(\mathrm{M}=\mathrm{Na}, \mathrm{K}, \mathrm{Rb})$ mixtures at low temperatures. Int. J. Hydrog. Energy 2012, 37, 4259-4266. [CrossRef]

223. Choi, Y.J.; Xu, Y.; Shaw, W.J.; Rönnebro, E.C.E. Hydrogen storage properties of new hydrogen-rich $\mathrm{BH}_{3} \mathrm{NH}_{3}$-metal hydride $\left(\mathrm{TiH}_{2} ; \mathrm{ZrH}_{2} ; \mathrm{MgH}_{2} ;\right.$ and/or $\left.\mathrm{CaH}_{2}\right)$ composite systems. J. Phys. Chem. C 2012, 116, 8349-8358. [CrossRef]

224. Kobayashi, T.; Hlova, I.Z.; Singh, N.A.; Pecharsky, V.A.; Pruski, M. Solid-state NMR study of Li-assisted dehydrogenation of ammonia borane. Inorg. Chem. 2012, 51, 4108-4115. [CrossRef]

225. Wan, L.; Chen, J.; Tan, Y.; Gu, Q.; Yu, X. Ammonia borane destabilized by aluminium hydride: A mutual enhancement for hydrogen release. Int. J. Hydrog. Energy 2015, 40, 1047-1053. [CrossRef]

226. Neiner, D.; Karkamkar, A.; Linehan, J.C.; Arey, B.; Autrey, T.; Kauzlarich, S.M. Promotion of hydrogen release from ammonia borane with mechanically activated hexagonal boron nitride. J. Phys. Chem. C 2009, 113, 1098-1103. [CrossRef] 
227. Neiner, D.; Luedtke, A.; Karkamkar, A.; Shaw, W.; Wang, J.; Browning, N.D.; Autrey, T.; Kauzlarich, S.M. Decomposition pathway of ammonia borane on the surface of nano-BN. J. Phys. Chem. C 2010, 114, 13935-13941. [CrossRef]

228. Gangal, A.C.; Kale, P.; Edla, R.; Manna, J.; Sharma, P. Study of kinetics and thermal decomposition of ammonia borane in presence of silicon nanoparticles. Int. J. Hydrog. Energy 2012, 37, 6741-6748. [CrossRef]

229. Jin, J.H.; Shin, S.; Jung, J.; Attia, N.F. Solid-phase hydrogen storage based on NH3BH3-SiO2 nanocomposite for thermolysis. J. Nanomater. 2019, 2019, 6126031. [CrossRef]

230. Kumar, D.; Mangalvedekar, H.A.; Mahajan, S.K. Nano-nickel catalytic dehydrogenation of ammonia borane. Mater. Renew. Sust. Energy 2014, 3, 23. [CrossRef]

231. Hwang, H.T.; Varma, A. Effect of boric acid on thermal dehydrogenation of ammonia borane: Mechanistic studies. Int. J. Hydrog. Energy 2013, 38, 1925-1931. [CrossRef]

232. Ergüven, H.; Kantürk Figen, A.; Pişkin, S. Ammonia borane-boron composites for hydrogen release: Thermolysis kinetics. Energy Sources A 2017, 39, 613-617. [CrossRef]

233. Shin, S.; Jin, J.H.; Jung, J. Sugar acid-assisted thermolysis of all-solid-state ammonia borane hydrogen fuel. Energy Technol. 2020, 8, 1901195. [CrossRef]

234. Kim, G.J.; Boone, A.M.; Chesnut, M.; Shin, J.H.; Jung, J.; Hwang, H.T. Enhanced thermal dehydrogenation of ammonia borane by D-mannitol. Ind. Eng. Chem. Res. 2020, 59, 620-626. [CrossRef]

235. Kim, Y.; Baek, H.; Lee, J.H.; Yeo, S.; Kim, K.; Hwang, S.J.; Eun, B.; Nam, S.W.; Lim, T.H.; Yoon, C.W. Metal-free; polyether-mediated $\mathrm{H}_{2}$-release from ammonia borane: Roles of hydrogen bonding interactions in promoting dehydrogenation. Phys. Chem. Chem. Phys. 2013, 15, 19584-19594. [CrossRef]

236. Yeo, S.; Kim, Y.; Lee, J.H.; Kim, A.; Jang, J.H.; Hong, S.A.; Nam, S.W.; Yoon, C.W. Promotional effects of oxygen-containing additives on ammonia borane dehydrogenation for polymer electrolyte membrane fuel cell applications. Int. J. Hydrog. Energy 2014, 39, 21786-21795. [CrossRef]

237. Kim, Y.; Kim, Y.; Yeo, S.; Kim, A.; Koh, J.E.; Seo, J.E.; Shin, S.J.; Choi, D.K.; Yoon, C.W.; Nam, S.W. Development of a continuous hydrogen generator fueled by ammonia borane for portable fuel cell applications. J. Power Sources 2013, 229, 170-178. [CrossRef]

238. de Jongh, P.E.; Adelhelm, P. Nanosizing and nanoconfinement: New strategies towards meeting hydrogen storage goals. ChemSusChem 2010, 3, 1332-1348. [CrossRef] [PubMed]

239. Wahab, M.A.; Zhao, H.; Yao, X.D. Nano-confined ammonia borane for chemical hydrogen storage. Front. Chem. Sci. Eng. 2012, 6, 27-33. [CrossRef]

240. Rossin, A.; Tuci, G.; Luconi, L.; Giambastiani, G. Metal-organic frameworks as heterogenous catalysts in hydrogen production from lightweight inorganic hydrides. ACS Catal. 2017, 7, 5035-5045. [CrossRef]

241. Rueda, M.; Sanz-Moral, L.M.; Martin, A. Innovative methods to enhance the properties of solid hydrogen storage materials based on hydrides through nanoconfinement: A review. J. Supercrit. Fluids 2018, 141, 198-217. [CrossRef]

242. Lai, S.W.; Lin, H.L.; Yu, T.L.; Lee, L.P.; Weng, B.J. Hydrogen release from ammonia borane embedded in mesoporous silica scaffolds: SBA-15 and MCM-41. Int. J. Hydrog. Energy 2012, 37, 14393-14404. [CrossRef]

243. Zhao, Y.; Zhang, J.; Akins, D.L.; Lee, J.W. Effect of composition on dehydrogenation of mesoporous silica/ammonia borane nanocomposites. Ind. Eng. Chem. Res. 2011, 50, 10024-10028. [CrossRef]

244. Sullivan, J.A.; Herron, R.; Phillips, A.D. Towards an understanding of the beneficial effect of mesoporous materials on the dehydrogenation characteristics of $\mathrm{NH}_{3} \mathrm{BH}_{3}$. Appl. Catal. B Env. 2017, 201, 182-188. [CrossRef]

245. Zhang, T.; Yang, X.; Yang, S.; Li, D.; Cheng, F.; Tao, Z.; Chen, J. Silica hollow nanospheres as new nanoscaffold materials to enhance hydrogen releasing from ammonia borane. Phys. Chem. Chem. Phys. 2011, 13, 18592-18599. [CrossRef]

246. Rueda, M.; Sanz-Moral, L.M.; Segovia, J.J.; Martín, A. Improvement of the kinetics of hydrogen release from ammonia borane confined in silica aerogel. Microp. Mesop. Mater. 2017, 237, 189-200. [CrossRef]

247. Colognesi, D.; Ulivi, L.; Zoppi, M.; Ramirez-Cuesta, A.J.; Orecchini, A.; Karkamkar, A.J.; Fichtner, M.; Gil Bardaji, E.; Zhao-Karger, Z. Hydrogen-storage materials dispersed into nanoporous substrates studied through incoherent inelastic neutron scattering. J. Alloys Compd. 2012, 538, 91-99. [CrossRef]

248. Kim, H.; Karkamkar, A.; Autrey, T.; Chupas, P.; Proffen, T. Determination of structure and phase transition of light element nanocomposites in mesoporous silica: Case study of $\mathrm{NH}_{3} \mathrm{BH}_{3}$ in $\mathrm{MCM}-41$. J. Am. Chem. Soc. 2009, 131, 13749-13755. [CrossRef] 
249. Paolone, A.; Palumbo, O.; Rispoli, P.; Cantelli, R.; Autrey, T.; Karkamkar, A. Absence of the structural phase transition in ammonia borane dispersed in mesoporous silica: Evidence of novel thermodynamic properties. J. Phys. Chem. C 2009, 113, 10319-10321. [CrossRef]

250. Valero-Pedraza, M.J.; Gascon, V.; Carreon, M.; Leardini, F.; Ares, J.R.; Martin, A.; Sanchez-Sanchez, M.; Banares, M. Operando Raman-mass spectrometry investigation of hydrogen release by thermolysis of ammonia borane confined in mesoporous materials. Microp. Mesop. Mater. 2016, 226, 454-465. [CrossRef]

251. Rueda, M.; Sanz-Moral, L.M.; Nieto-Márquez, A.; Longone, P.; Mattea, F.; Martin, A. Production of silica aerogel microparticles loaded with ammonia borane by batch and semicontinuous supercritical drying techniques. J. Supercrit. Fluids. 2014, 92, 299-310. [CrossRef]

252. Feng, Y.; Zhou, X.; Yang, J.H.; Gao, X.; Yin, L.; Zhao, Y.; Zhang, B. Encapsulation of ammonia borane in Pd/halloysite nanotubes for efficient thermal dehydrogenation. ACS Sust. Chem. Eng. 2010, 8, 2122-2129. [CrossRef]

253. Richard, J.; Cid, S.L.; Rouquette, J.; van de Lee, A.; Bernard, S.; Haines, J. Pressure-induced insertion of ammonia borane in the siliceous zeolite; silicalite-1F. J. Phys. Chem. C 2016, 120, 9334-9340. [CrossRef]

254. Feaver, A.; Sepehri, S.; Shamberger, P.; Stowe, A.; Autrey, T.; Cao, G. Coherent carbon cryogel-ammonia borane nanocomposites for $\mathrm{H}_{2}$ storage. J. Phys. Chem. B 2007, 111, 7469-7472. [CrossRef]

255. Sepehri, S.; García, B.B.; Cao, G. Influence of surface chemistry on dehydrogenation in carbon cryogel ammonia borane nanocomposites. Eur. J. Inorg. Chem. 2009, 2009, 599-603. [CrossRef]

256. Moussa, G.; Bernard, S.; Demirci, U.B.; Chiriac, R.; Miele, P. Room-temperature hydrogen release from activated carbon-confined ammonia borane. Int. J. Hydrog. Energy 2012, 37, 13437-13445. [CrossRef]

257. Bravo Diaz, L.; Hanlon, J.M.; Bielewski, M.; Milewska, A.; Gregory, D.H. Ammonia borane based nanocomposites as solid-state hydrogen stores for portable power applications. Energy Technol. 2018, 6, 583-594. [CrossRef]

258. Li, L.; Yao, X.; Sun, C.; Du, A.; Cheng, L.; Zhu, Z.; Yu, C.; Zou, J.; Simth, S.C.; Wang, P.; et al. Lithium-catalyzed dehydrogenation of ammonia borane within mesoporous carbon framework for chemical hydrogen storage. Adv. Funct. Mater. 2009, 19, 265-271. [CrossRef]

259. Yang, Z.; Zhou, D.; Chen, B.; Liu, Z.; Xia, Q.; Zhu, Y.; Xia, Y. Improved hydrogen release from ammonia borane confined in microporous carbon with narrow pore size distribution. J. Mater. Chem. A 2017, 5, 15395-15400. [CrossRef]

260. Zhang, L.; Xia, G.; Ge, Y.; Wang, C.; Guo, Z.; Li, X.; Yu, X. Ammonia borane confined by nitrogen-containing carbon nanotubes: Enhanced dehydrogenation properties originating from synergetic catalysis and nanoconfinement. J. Mater. Chem. A 2015, 3, 20494-20499. [CrossRef]

261. Tang, Z.; Chen, H.; Chen, X.; Wu, L.; Yu, X. Graphene oxide based recyclable dehydrogenation of ammonia borane within a hybrid nanostructure. J. Am. Chem. Soc. 2012, 134, 5464-5467. [CrossRef]

262. So, S.H.; Jang, J.H.; Sung, S.J.; Yang, S.J.; Nam, K.T.; Park, C.R. Demonstration of the nanosize effect of carbon nanomaterials on the dehydrogenation temperature of ammonia borane. Nanoscale Adv. 2019, 1, 4697-4703. [CrossRef]

263. Klooster, W.T.; Koetzle, T.F.; Siegbahn, P.E.M.; Richardson, T.B.; Crabtree, R.H. Study of the N-H..H-B dihydrogen bond including the crystal structure of $\mathrm{BH}_{3} \mathrm{NH}_{3}$ by neutron diffraction. J. Am. Chem. Soc. 1999, 121, 6337-6343. [CrossRef]

264. Kuang, A.; Liu, T.; Kuang, M.; Yang, R.; Huang, R.; Wang, G.; Yuan, H.; Chen, H.; Yang, X. Hydrogen bonding-mediated dehydrogenation in the ammonia borane combined graphene oxide systems. Phys. E 2018, 97, 75-81. [CrossRef]

265. Sepehri, S.; Feaver, A.; Shaw, W.J.; Howard, C.J.; Zhang, Q.; Autrey, T.; Cao, G. Spectroscopic studies of dehydrogenation of ammonia borane in carbon cryogel. J. Phys. Chem. B 2007, 111, 14285-14289. [CrossRef]

266. Sepehri, S.; Garcia, B.B.; Zhang, Q.; Cao, G. Influences of surface chemistry on dehydrogenation of ammonia borane in porous carbon scaffold. Adv. Mater. Res. 2010, 132, 19-28. [CrossRef]

267. Champet, S.; van den Berg, J.; Szczesny, R.; Godula-Jopek, A.; Gregory, D.H. Nano-inclusion in one step: Spontaneous ice-templating of porous hierarchical nanocomposites for selective hydrogen release. Sust. Energy Fuels 2019, 3, 396-400. [CrossRef]

268. Li, Z.; Zhu, G.; Lu, G.; Qiu, S.; Yao, X. Ammonia borane confined by a metal-organic framework for chemical hydrogen storage: Enhancing kinetics and eliminating ammonia. J. Am. Chem. Soc. 2010, 132, 1490-1491. [CrossRef] [PubMed] 
269. Gadipelli, S.; Ford, J.; Zhou, W.; Wu, H.; Udovic, T.J.; Yildirim, T. Nanoconfinement and catalytic dehydrogenation of ammonia borane by magnesium-metal-organic-framework-74. Chem. Eur. J. 2011, 17, 6043-6047. [CrossRef] [PubMed]

270. Srinivas, G.; Travis, W.; Ford, J.; Wu, H.; Guo, Z.X.; Yildirim, T. Nanoconfined ammonia borane in a flexible metal-organic framework Fe-MIL-53: Clean hydrogen release with fast kinetics. J. Mater. Chem. A 2013, 1, 4167-4172. [CrossRef]

271. Si, X.L.; Sun, L.X.; Xu, F.; Jiao, C.L.; Li, F.; Liu, S.S.; Zhang, J.; Song, L.F.; Jiang, C.H.; Wang, S.; et al. Improved hydrogen desorption properties of ammonia borane by Ni-modified metal-organic frameworks. Int. J. Hydrog. Energy 2011, 36, 6698-6704. [CrossRef]

272. Jeong, H.M.; Shin, W.H.; Park, J.H.; Choi, J.H.; Kang, J.K. A metal-organic framework as a chemical guide to control hydrogen desorption pathways of ammonia borane. Nanoscale 2014, 6, 6526-6530. [CrossRef]

273. Yang, H.; Li, Z.; Liu, A.; Meng, F.; Niu, C. Clean hydrogen release from ammonia borane in a metal-organic framework with unsaturated coordinated $\mathrm{Tm}^{3+}$. J. Phys. Chem. C 2015, 119, 2260-2265. [CrossRef]

274. Chung, J.Y.; Liao, C.W.; Chang, Y.W.; Chang, B.A.; Wang, H.; Li, J.; Wang, C.Y. Influence of metal-organic framework porosity on hydrogen generation from nanoconfined ammonia borane. J. Phys. Chem. C 2017, 121, 27369-27378. [CrossRef]

275. Li, Z.; Liu, W.; Yang, H.; Sun, T.; Liu, K.; Wang, Z.; Niu, C. Improved thermal dehydrogenation of ammonia borane by MOF-5. RSC Adv. 2015, 5, 10746-10750. [CrossRef]

276. Zhong, R.Q.; Zou, R.Q.; Nakagawa, T.; Janicke, M.; Semelsberger, T.A.; Burrell, A.K.; Del Sesto, R.E. Improved hydrogen release from ammonia-borane with ZIF-8. Inorg. Chem. 2012, 51, 2728-2730. [CrossRef] [PubMed]

277. Srinivas, G.; Ford, J.; Zhou, W.; Yildirim, T. Zn-MOF assisted dehydrogenation of ammonia borane: Enhanced kinetics and clean hydrogen generation. Int. J. Hydrog. Energy 2012, 37, 3633-3638. [CrossRef]

278. Kong, S.; Dai, R.; Li, H.; Sun, W.; Wang, Y. Microwave hydrothermal synthesis of Ni-based metal-organic frameworks and their derived yolk-shell $\mathrm{NiO}$ for Li-ion storage and supported ammonia borane for hydrogen desorption. ACS Sust. Chem. Eng. 2015, 3, 1830-1838. [CrossRef]

279. Wu, Y.J.; Wang, C.Y. Insight into the catalytic effects of open metal sites in metal-organic frameworks on hydride dehydrogenation via nanoconfinement. ACS Sust. Chem. Eng. 2019, 7, 16013-16025. [CrossRef]

280. Zhao, J.; Shi, J.; Zhang, X.; Cheng, F.; Liang, J.; Tao, Z.; Chen, J. A soft hydrogen storage material: Poly(methyl acrylate)-confined ammonia borane with controllable dehydrogenation. Adv. Mater. 2009, 22, 394-397. [CrossRef]

281. Li, S.F.; Tang, Z.W.; Tan, Y.B.; Yu, X.B. Polyacrylamide blending with ammonia borane: A polymer supported hydrogen storage composite. J. Phys. Chem. C 2012, 116, 1544-1549. [CrossRef]

282. Seemaladinne, R.; Pati, S.; Kharel, A.; Bafana, A.; Al-Wahish, A.; Wujcik, E.K.; Günaydin-Sen, Ö. Ammonia borane with polyvinylpyrrolidone as a hydrogen storage material: Comparison of different molecular weights. J. Phys. Chem. Solids 2017, 110, 394-400. [CrossRef]

283. Tang, Z.; Li, S.; Yang, W.; Yu, X. Hypercrosslinked porous poly(styrene-co-divinylbenzene) resin: A promising nanostructure-incubator for hydrogen storage. J. Mater. Chem. 2012, 22, 12752-12758. [CrossRef]

284. Kurban, Z.; Lovell, A.; Bennington, S.M.; Jenkins, D.W.A.; Ryan, K.R.; Jones, M.O.; Skipper, N.T.; David, W.I.F. A solution selection model for coaxial electrospinning and its application to nanostructured hydrogen storage materials. J. Phys. Chem. C 2010, 114, 21201-21213. [CrossRef]

285. Tang, Z.; Li, S.; Yang, Z.; Yu, X. Ammonia borane nanofibers supported by poly(vinyl pyrrolidone) for dehydrogenation. J. Mater. Chem. 2011, 21, 14616-14621. [CrossRef]

286. Alipour, J.; Shoushtari, A.M.; Kaflou, A. Electrospun PMMA/AB nanofiber composites for hydrogen storage applications. e-Polymers 2014, 14, 305-311. [CrossRef]

287. Nathanson, A.S.; Ploszajski, A.R.; Billing, M.; Cook, J.P.; Jenkins, D.W.K.; Headen, T.F.; Kurban, Z.; Lovell, A.; Bennington, S.M. Ammonia borane-polyethylene oxide composite materials for solid hydrogen storage. J. Mater. Chem. A 2015, 3, 3683-3691. [CrossRef]

288. Kharel, A.; Gangineni, R.; Ware, L.; Lu, Y.; Wujcik, E.K.; Wei, S.; Günaydin-Sen, Ö. Dehydrogenation properties of ammonia borane-polyacrylamide nanofiber hydrogen storage composites. J. Mater. Sci. 2017, 52, 4894-4902. [CrossRef]

289. Ploszajski, A.R.; Billing, M.; Nathanson, A.S.; Vickers, S.; Bennington, S.M. Freeze-dried ammonia borane-polyethylene oxide composites: Phase behaviour and hydrogen release. Int. J. Hydrog. Energy 2018, 43, 5645-5656. [CrossRef] 
290. Ploszajski, A.R.; Billing, M.; Cockcroft, J.A.; Skipper, N.T. Crystalline structure of an ammonia borane-polyethylene oxide cocrystal: A material investigated for its hydrogen storage potential. CrystEngComm 2018, 20, 4436-4440. [CrossRef]

291. Moussa, G.; Demirci, U.B.; Malo, S.; Bernard, S.; Miele, P. Hollow core@mesoporous shell boron nitride nanopolyhedron-confined ammonia borane: A pure B-N-H composite for chemical hydrogen storage. J. Mater. Chem. A 2014, 2, 7717-7722. [CrossRef]

292. Yang, Z.; Liang, J.; Cheng, F.; Tao, Z.; Chen, J. Porous $\mathrm{MnO}_{2}$ hollow cubes as new nanoscaffold materials for the dehydrogenation promotion of ammonia-borane (AB). Microp. Mesop. Mater. 2012, 161, 40-47. [CrossRef]

293. Yang, Z.; Sun, H.; Li, H.; Li, F.; Qijing, H.; Zhang, Y. Enhancing the thermal dehydrogenation properties of ammonia borane (AB) by using monodisperse $\mathrm{MnO}_{2}$ hollow spheres (MHS). J. Alloys Compd. 2019, 781, 111-117. [CrossRef]

294. Niedenzu, P.M. Studies on Polyboron Hydride Anions and Ammine-Borane. Ph.D. Thesis, The Ohio State University, Columbus, OH, USA, 1990.

295. Salupo, T. Preparations of Ytterbium and Europium Borides from $\mathrm{Yb}$ (II) and Eu(II) Boron Hydride Precursors. Ph.D. Thesis, The Ohio State University, Columbus, OH, USA, 1993.

296. DeGraffenreid, A.L. Studies on Boron-Nitrogen and Boron-Gadolinium Compounds. Ph.D. Thesis, The Ohio State University, Columbus, OH, USA, 1995.

297. Myers, A.G.; Yang, B.H.; Kopecky, D.J. Lithium amidotrihydroborate; a powerful new reductant. Transformation of tertiary amides to primary alcohols. Tetrahedron Lett. 1996, 37, 3623-3626. [CrossRef]

298. Diyabalanage, H.V.A.; Shrestha, R.P.; Semelsberger, T.A.; Scott, B.L.; Bowden, M.E.; Davis, B.L.; Burrell, A.K. Calcium amidotrihydroborate: A hydrogen storage material. Angew. Chem. Int. Ed. 2007, 46, 8995-8997. [CrossRef]

299. Chua, Y.S.; Chen, P.; Wu, G.; Xiong, Z. Development of amidoboranes for hydrogen storage. Chem. Commun. 2011, 47, 5116-5129. [CrossRef] [PubMed]

300. Wang, A.; Zhang, J.G.; Man, T.T.; Wu, M.; Chen, C.C. Recent progress and development of metal amidoborane. Chem. Asian J. 2013, 8, 1076-1089. [CrossRef] [PubMed]

301. Owarzany, R.; Leszczyński, P.J.; Fijalkowski, K.J.; Grochala, W. Mono- and bimetallic amidoboranes. Crystals 2016, 6, 88. [CrossRef]

302. Castilla-Martinez, C.A.; Moury, R.; Demirci, U.B. Amidoboranes and hydrazinidoboranes: State of the art, potential for hydrogen storage; and other prospects. Int. J. Hydrog. Energy 2020. submitted.

303. Liu, X.; Wu, Y.; Wang, S.; Li, Z.; Guo, X.; Ye, J.; Jiang, L. Current progress and research trends on lithium amidoborane for hydrogen storage. J. Mater. Sci. 2020, 55, 2645-2660. [CrossRef]

304. Xiong, Z.; Yong, C.A.; Wu, G.; Chen, P.; Shaw, W.; Karkamkar, A.; Autrey, T.; Jones, M.O.; Johnson, S.R.; Edwards, P.P.; et al. High-capacity hydrogen storage in lithium and sodium amidoboranes. Nat. Mater. 2008, 7, 138-141. [CrossRef]

305. Wu, C.; Wu, G.; Xiong, Z.; David, W.I.F.; Ryan, K.R.; Jones, M.O.; Edwards, P.P.; Chu, H.; Chen, P. Stepwise phase transition in the formation of lithium amidoborane. Inorg. Chem. 2010, 49, 4319-4323. [CrossRef]

306. Liu, L.; Wang, S.; Wu, Y.; Li, Z.; Jiang, L.; Guo, X.; Ye, J. Dehydrogenation of two phases of $\mathrm{LiNH}_{2} \mathrm{BH}_{3}$. Int. J. Hydrog. Energy 2020, 45, 2127-2134. [CrossRef]

307. Luedtke, A.T.; Autrey, T. Hydrogen release studies of alkali amidoboranes. Inorg. Chem. 2010, 49, 3905-3910. [CrossRef]

308. Shimoda, A.; Doi, A.; Nakagawa, T.; Zhang, Y.; Miyaoka, H.; Ichikawa, T.; Tansho, M.; Shimizu, T.; Burrell, A.K.; Kojima, Y. Comparative study of structural changes in $\mathrm{NH}_{3} \mathrm{BH}_{3}, \mathrm{LiNH}_{2} \mathrm{BH}_{3}$, and $\mathrm{KNH}_{2} \mathrm{BH}_{3}$ during dehydrogenation process. J. Phys. Chem. C 2012, 116, 5957-5964. [CrossRef]

309. Xiong, Z.; Wu, G.; Chua, Y.S.; Hu, J.; He, T.; Xu, W.; Chen, P. Synthesis of sodium amidoborane $\left(\mathrm{NaNH}_{2} \mathrm{BH}_{3}\right)$ for hydrogen production. Energy Environ. Sci. 2008, 1, 360-363. [CrossRef]

310. Sandra, F.P.R.; Demirci, U.B.; Chiriac, R.; Moury, R.; Miele, P. A simple preparation method of sodium amidoborane; highly efficient derivative of ammonia borane dehydrogenating at low temperature. Int. J. Hydrog. Energy 2011, 36, 7423-7430. [CrossRef]

311. Harder, S. Molecular early main group metal hydrides: Synthetic challenge, structures and applications. Chem. Commun. 2012, 48, 11165-11177. [CrossRef] [PubMed] 
312. Fijałkowski, K.J.; Grochala, W. Substantial emission of $\mathrm{NH}_{3}$ during thermal decomposition of sodium amidoborane; $\mathrm{NaNH}_{2} \mathrm{BH}_{3}$. J. Mater. Chem. 2009, 19, 2043-2050. [CrossRef]

313. Diyabalanage, H.V.A.; Nakagawa, T.; Shrestha, R.P.; Semelsberger, T.A.; Davis, B.L.; Scott, B.L.; Burell, A.K.; David, W.I.F.; Ryan, K.R.; Jones, M.O.; et al. Potassium(I) amidotrihydroborate: Structure and hydrogen release. J. Am. Chem. Soc. 2010, 132, 11836-11837. [CrossRef]

314. Owarzany, R.; Jaroń, T.; Leszczyński, P.J.; Fijalkowski, K.J.; Grochala, W. Amidoborane of rubidium and caesium: The last missing members of the alkali metal amidoborane family. Dalton Trans. 2017, 46, 16315-16320. [CrossRef]

315. Kazakov, I.V.; Butlak, A.V.; Shelyganov, P.A.; Suslonov, V.V.; Timoshkin, A.Y. Reversible structural transformations of rubidium and cesium amidoboranes. Polyhedron 2017, 127, 186-190. [CrossRef]

316. Ramzan, M.; Silverav, F.; Blomqvist, A.; Scheicher, R.H.; Lebègue, S. Structural and energetic analysis of the hydrogen storage materials $\mathrm{LiNH}_{2} \mathrm{BH}_{3}$ and $\mathrm{NaNH}_{2} \mathrm{BH}_{3}$ from ab initio calculation. Phys. Rev. B 2009, 79, 132102. [CrossRef]

317. Wu, H.; Zhou, W.; Yildirim, T. Alkali, and alkaline-earth metal amidoboranes: Structure, crystal chemistry, and hydrogen storage properties. J. Am. Chem. Soc. 2008, 130, 14834-14839. [CrossRef]

318. Davydova, E.I.; Lisovenko, A.S.; Timoshkin, A.Y. Complex beryllium amidoboranes: Structures, stability, and evaluation of their potential as hydrogen storage materials. J. Comput. Chem. 2017, 38, 401-405. [CrossRef]

319. Nakagawa, Y.; Isobe, S.; Ikarashi, Y.; Ohnuki, S. AB-MH (ammonia borane-metal hydride) composites: Systematic understanding of dehydrogenation properties. J. Mater. Chem. A 2014, 2, 3926-3931. [CrossRef]

320. Luo, J.; Kang, X.; Wang, P. Synthesis, formation mechanism, and dehydrogenation properties of the long-sought $\mathrm{Mg}\left(\mathrm{NH}_{2} \mathrm{BH}_{3}\right)_{2}$ compound. Energy Environ. Sci. 2013, 6, 1018-1025. [CrossRef]

321. Leardini, F.; Ares, J.R.; Bodega, J.; Valero-Pedraza, M.J.; Bañares, M.A.; Fernandez, J.F.; Sanchez, C. Hydrogen desorption behavior of calcium amidoborane obtained by reactive milling of calcium hydride and ammonia borane. J. Phys. Chem. C 2012, 116, 24430-24435. [CrossRef]

322. Zhang, Q.; Tang, C.; Fang, C.; Fang, F.; Sun, D.; Ouyang, L.; Zhu, M. Synthesis, crystal structure; and thermal decomposition of strontium amidoborane. J. Phys. Chem. C 2010, 114, 1709-1714. [CrossRef]

323. Shcherbina, N.A.; Kazakov, I.V.; Timoshkin, A.Y. Synthesis and characterization of barium amidoborane. Russ. J. Gen. Chem. 2017, 87, 2875-2877. [CrossRef]

324. Smythe, N.C.; Gordon, J.C. Ammonia borane as a hydrogen carrier: Dehydrogenation and regeneration. Eur. J. Inorg. Chem. 2010, 2010, 509-521. [CrossRef]

325. Hausdorf, S.; Baitalow, F.; Wolf, G.; Mertens, F.O.R.L. A procedure of the regeneration of ammonia borane from BNH-waste products. Int. J. Hydrog. Energy 2008, 33, 608-614. [CrossRef]

326. Reller, C.; Mertens, F.O.R.L. A self-containing regeneration scheme for spent ammonia borane on the catalytic hydrodechlorination of $\mathrm{BCl}_{3}$. Angew. Chem. Int. Ed. 2012, 51, 11731-11735. [CrossRef]

327. Davis, D.L.; Dixon, D.A.; Garner, E.B.; Gordon, J.C.; Matus, M.H.; Scott, B.; Stephens, F.H. Efficient regeneration of partially spent ammonia borane fuel. Angew. Chem. Int. Ed. 2009, 48, 6812-6816. [CrossRef]

328. Tan, Y.; Zhang, L.; Chen, X.; Yu, X. Reductive dechlorination of $\mathrm{BCl} 3$ for efficient ammonia borane regeneration. Dalton Trans. 2015, 44, 753-757. [CrossRef]

329. Sutton, A.D.; Burrell, A.A.; Dixon, D.A.; Garner, E.B., III; Gordon, J.C.; Nakagawa, T.; Ott, K.C.; Robinson, J.P.; Vasiliu, M. Regeneration of ammonia borane spent fuel by direction reaction with hydrazine and liquid ammonia. Science 2011, 331, 1426-1429. [CrossRef] [PubMed]

330. Hua, T.Q.; Ahluwalia, R.K. Off-board regeneration of ammonia borane for use as a hydrogen carrier for automotive fuel cells. Int. J. Hydrog. Energy 2012, 37, 14382-14392. [CrossRef]

331. Tang, Z.; Tan, Y.; Chen, X.; Yu, X. Regenerable hydrogen storage in lithium amidoborane. Chem. Commun. 2012, 48, 9296-9298. [CrossRef] [PubMed]

332. Tang, Z.; Zhang, L.; Wan, L.; Huang, Z.; Liu, H.; Guo, Z.; Yu, X. Regeneration of alkaline metal amidoboranes with high purity. Int. J. Hydrog. Energy 2016, 41, 407-412. [CrossRef]

333. Marder, T.B. Will we soon be fueling our automobiles with ammonia borane? Angew. Chem. Int. Ed. 2007, 46, 8116-8118. [CrossRef]

334. Companies House. Available online: https://beta.companieshouse.gov.uk/company/09019506/insolvency (accessed on 2 May 2020). 
335. First UAV test flight with Cella solid-state hydrogen storage. Fuel Cells Bull. 2016, 3, 4-5.

336. Energy.gov. Available online: https://www.energy.gov/sites/prod/files/2017/05/f34/fcto_targets_onboard_ hydro_storage_explanation.pdf (accessed on 2 May 2020).

(c)

(C) 2020 by the author. Licensee MDPI, Basel, Switzerland. This article is an open access article distributed under the terms and conditions of the Creative Commons Attribution (CC BY) license (http://creativecommons.org/licenses/by/4.0/). 